\title{
Assessment of molecular action of direct gating and allosteric modulatory effects of carisoprodol (SomaRTM) on GABA A receptors
}

Manoj Kumar

Follow this and additional works at: https://researchrepository.wvu.edu/etd

\section{Recommended Citation}

Kumar, Manoj, "Assessment of molecular action of direct gating and allosteric modulatory effects of carisoprodol (SomaRTM) on GABA A receptors" (2015). Graduate Theses, Dissertations, and Problem Reports. 6022.

https://researchrepository.wvu.edu/etd/6022

This Dissertation is protected by copyright and/or related rights. It has been brought to you by the The Research Repository @ WVU with permission from the rights-holder(s). You are free to use this Dissertation in any way that is permitted by the copyright and related rights legislation that applies to your use. For other uses you must obtain permission from the rights-holder(s) directly, unless additional rights are indicated by a Creative Commons license in the record and/ or on the work itself. This Dissertation has been accepted for inclusion in WVU Graduate Theses, Dissertations, and Problem Reports collection by an authorized administrator of The Research Repository @ WVU.

For more information, please contact researchrepository@mail.wvu.edu. 
ASSESSMENT OF MOLECULAR ACTION OF DIRECT GATING AND

ALLOSTERIC MODULATORY EFFECTS OF MEPROBAMATE (MILTOWN®)

ON GABAA RECEPTORS

Manish Kumar, MD, MS

Dissertation submitted to the School of Pharmacy at

West Virginia University in partial fulfillment of

Requirements for the degree of

DOCTOR OF PHILOSOPHY

IN

PHARMACEUTICAL AND PHARMACOLOGICAL SCIENCES

Glenn H. Dillon, PhD., Chair

Rae Matsumoto, PhD

Patrick S. Callery, PhD

Hanting Zhang, MD, PhD

Robert K Griffith, PhD

Department of Pharmaceutical Sciences

Morgantown, West Virginia

May 2016

Keywords: GABAA receptors, GABAA receptor isoforms, Carisoprodol, Meprobamate,

Muscle relaxant, Drug Abuse

Copyright 2016 Manish Kumar 


\section{ABSTRACT \\ ASSESSMENT OF MOLECULAR ACTION OF DIRECT GATING AND ALLOSTERIC MODULATORY EFFECTS OF MEPROBAMATE (MILTOWN®) ON GABAA RECEPTORS}

\section{Manish Kumar}

Meprobamate (tradenames Miltown, Equanil) is a schedule IV anxiolytic and the primary metabolite of the muscle relaxant carisoprodol. Meprobamate modulates $\mathrm{GABA}_{\mathrm{A}}(\gamma-$ aminobutyric acid type A) receptors, and has been described as having barbiturate-like activity. A thorough understanding of its mechanism remains ill-defined, however. To gain insight into its actions, we have conducted a series of studies using recombinant $\mathrm{GABA}_{\mathrm{A}}$ receptors. In $\alpha x \beta z \gamma 2 \mathrm{GABA}_{\mathrm{A}}$ receptors (where $\mathrm{x}=1-6$ and $\mathrm{z}=1-3$ ), the ability to enhance GABA-mediated current was evident for all $\alpha$ subunit isoforms, with the largest effect observed in $\alpha 5$-expressing receptors. Direct gating was comparable with all $\alpha$ subunits, although the effect was attenuated in $\alpha 3$-expressing receptors. Allosteric potentiating and direct gating effects were comparable in $\alpha 1 \beta 1 \gamma 2$ and $\alpha 1 \beta 2 \gamma 2$ receptors, whereas allosteric effects were enhanced in $\alpha 1 \beta 2$ compared to $\alpha 1 \beta 2 \gamma 2$ receptors. In "extrasynaptic" $\mathrm{GABA}_{\mathrm{A}}$ receptors ( $\alpha 1 \beta 3 \delta$ and $\alpha 4 \beta 3 \delta$ receptors), meprobamate allosterically enhanced both $\mathrm{EC}_{20}$ and saturating GABA currents, and directly activated these receptors with an efficacy comparable to that of GABA. Bemegride, which antagonizes effects of pentobarbital, attenuated direct gating effects of meprobamate. Whereas pentobarbital directly gated homomeric $\beta 3$ receptors, meprobamate did not, and instead blocked the spontaneously open current present in these receptors. In wild type homomeric $\rho 1$ 
receptors, both pentobarbital and meprobamate were ineffective in direct gating; a mutation (W328M) previously shown to confer sensitivity to pentobarbital, did not confer sensitivity to meprobamate. Our results provide additional insight into the actions of meprobamate and parent therapeutic agents such as Carisoprodol as well as possible domains involved in the direct gating actions of the ligands including transmembrane domains TM4. Further, using sitedirected-mutagenesis and whole cell patch clamp electrophysiology in transiently transfected HEK293 cells, we examined the role of GABAA receptor $\alpha$-subunit transmembrane domain 4 (TM4) and transmembrane domain 2 (TM2) amino acids in direct gating, and inhibitory actions of meprobamate. Mutation of $\alpha 3$ valine at position 440 to leucine (present in the equivalent position in the $\alpha 1$ subunit) increased the direct gating potency and efficacy of meprobamate. In R- $\alpha 1 \beta 2$ heteromeric GABAA receptor, both pentobarbital and carisoprodol had inhibitory effect for allosteric modulatory action at higher concentrations. Meprobamate did not have an inhibitory effect at the concentrations tested. T6'F mutation of the $\beta 2$-subunit abolished the inhibition of carisoprodol but not of pentobarbital. Thus, our studies provide further insight into actions of meprobamate, its parent drug carisoprodol and their comparison to barbiturate pentobarbital. 


\section{DEDICATION}

I dedicate my dissertation to my mother Mrs. Manju Kumari whose tireless patience and encouragement helped me in toughest of the times. My Grand Father, Late Mr. Awadh Kishore Das. My aunt Bindu Kumari, whose first words when I joined medical school was, "win a Nobel prize in medicine". My father, Mr. Sachchidanand Roy, who stood behind me through thick and thin and last but not the least, my mentor Dr. Glenn H. Dillon. 


\section{ACKNOWLEDGMENTS}

I would like to thank these important people who have helped and guided me in achieving my goals.

Dr. Glenn H. Dillon: An excellent mentor, excellent scientist, excellent administrator, excellent family man and an amazing person. I am extremely lucky to have you as mentor for not only learning science but every moment spent with you was a learning experience. So, Thank you.

Dawn Dillon: An amazing person, who did not let us miss our family away from home. Thank you.

Dr. Rae Matsumoto, Dr. Patrick S. Callery, Dr. Hanting Zhang, Dr. Robert K Griffith: Thank you for being part of my committee and enriching my scientific experience with valuable suggestions.

My Family members, Siblings, Ashish Kumar, Madhulika Roy, Uncles, Ashok Kumar, Abhay Kumar, Friends, Lokesh Gowda, Ashwini Saxena, Vishal Yadav, Manoj Kumar, Abhishek Kumar, Anuj Kumar. Thank you all for the valuable support.

Lab members, Zheng-Ian, Ren-Qi-Huang, Cathy-Bell Horner, Manoj Kumar, John M. Freund for their valuable suggestions during day to day working in lab. 


\section{TABLE OF CONTENTS}

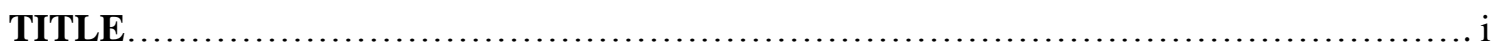

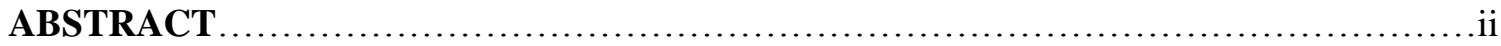

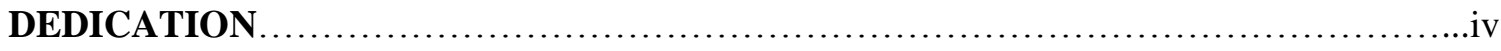

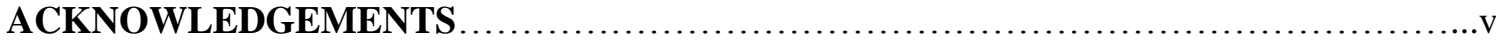

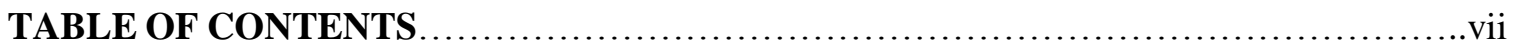

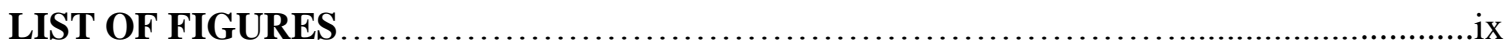

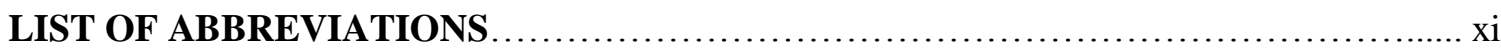

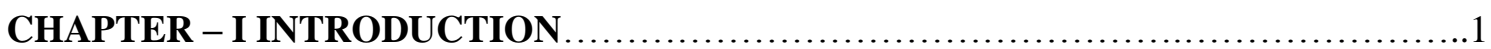

History of Meprobamate........................................................

Chemistry and Physiological Effects of Meprobamate..............................5

Pharmacology and Metabolism of Meprobamate.......................................

Side Effect, Abuse and Withdrawal of Meprobamate...................................8

GABAA Receptors..............................................................11

Structure of GABAA receptors and Subunit Classes and Roles.........................15

Various Modes of GABAA receptor Subunit Classes and Roles.........................17

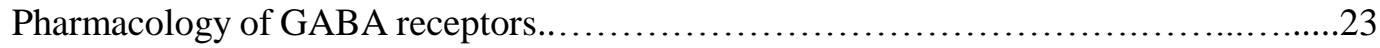

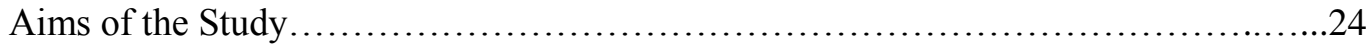

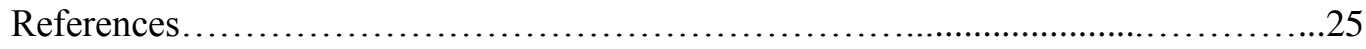

\section{CHAPTER - II ASSESSMENT OF DIRECT GATING}

AND ALLOSTERIC MODULATORY EFFECTS OF MEPROBAMATE IN

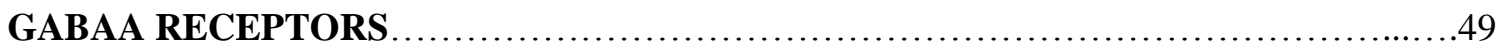

ABSTRACT .................................................................. 50

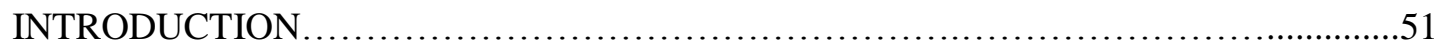




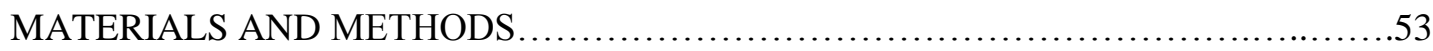

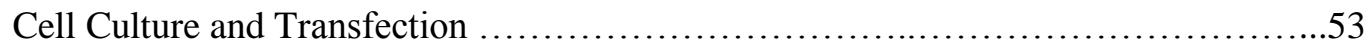

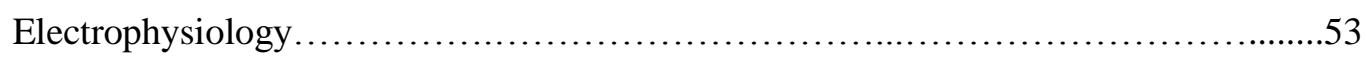

Chemicals and solutions....................................................54

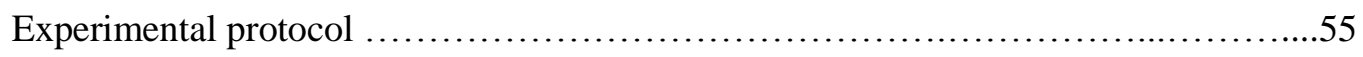

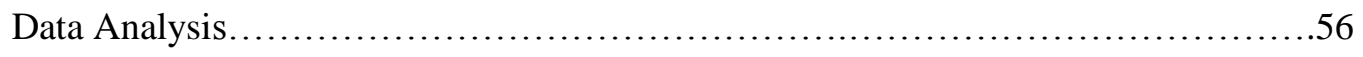

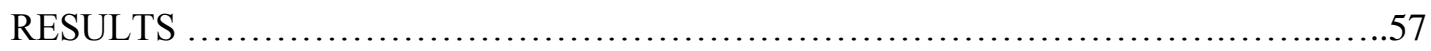

Influence of $\alpha$-subunit isoform of meprobamate-mediated activity of the

GABAA receptor........................................................ 57

Influence of $\beta$-subunit isoform of meprobamate-mediated activity of the

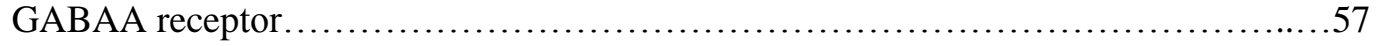

Influence of $\gamma$-subunit isoform of meprobamate-mediated activity of the

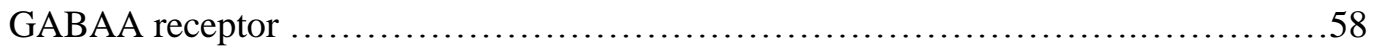

Effects of meprobamate in "extrasynaptic" receptors............................58

Further assessment of barbiturate like effects of meprobamate.....................59

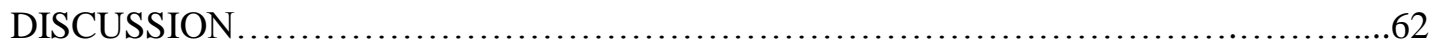

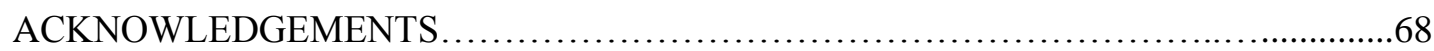

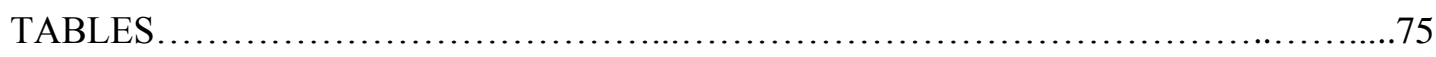

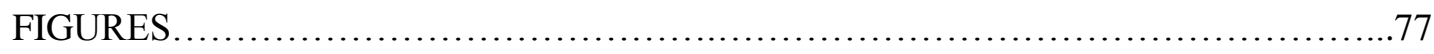

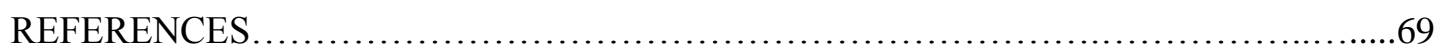

\section{CHAPTER - III A SINGLE AMINO ACID RESIDUE AT TRANSMEMBRANE 4 \\ OF THE ALPHA 1 SUBUNIT INFLUENCES CARISOPRODOL DIRECT}

GATING EFFICACY AT GABAA RECEPTORS ................................. 92

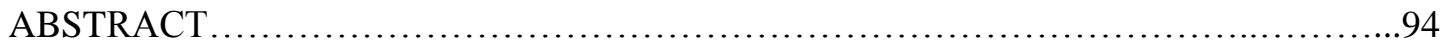

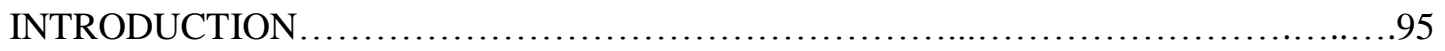


MATERIAL AND METHODS.............................................. 97

Cell Culture and Transfection...............................................97

Whole-cell patch clamp electrophysiology ..................................97

Chemicals and solutions................................................98

Experimental Protocol.....................................................98

Data Analysis......................................................... 99

Plasmids and site-directed-mutagenesis ................................... 100

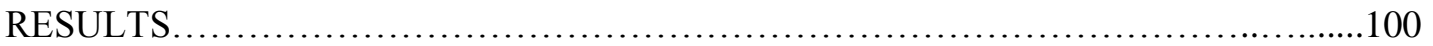

TM4 amino acid mutations $\alpha 3$ to corresponding $\alpha 1$, lead to gain in function of

meprobamate mediated direct gating....................................... 101

Carisoprodol and pentobarb, but not meprobamate show an inhibition and rebound at high concentrations in WT R- $\alpha 1 \beta 2$ GABAA receptors..........................101 T6'F mutation in $\beta 2$-subunit, attenuates inhibition and rebound (offshoot) currents in carisoprodol, but not in pentobarb...........................................102

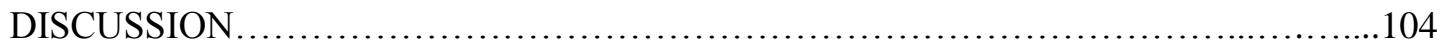

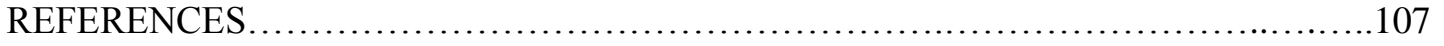

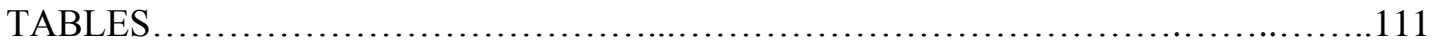

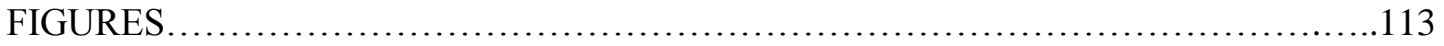

CHAPTER- IV SUMMARY, DISCUSSION AND FUTURE DIRECTIONS ..............122 


\section{LIST OF FIGURES}

I-1 Chemical structure of meprobamate and mephenesin. .4

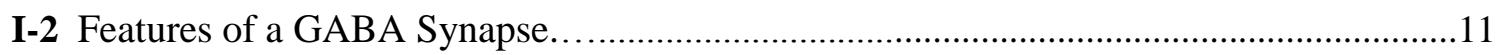

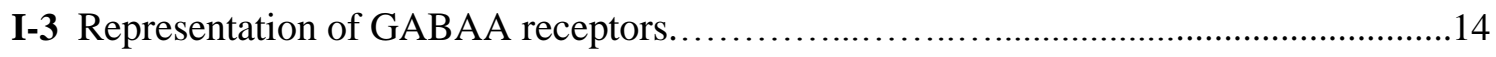

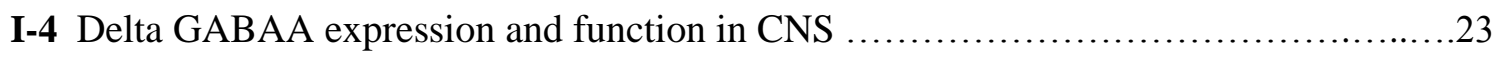

II-1 Structure of meprobamate and a prominent parent molecule, carisoprodol............................................................ 77

II-2 Assessment of subunit-dependent effects of meprobamate on direct activation of $\mathrm{GABA}_{\mathrm{A}}$ receptors........................................ 79

II-3 Assessment of subunit-dependent effects of allosteric modulatory effects of meprobamate on $\mathrm{GABA}_{\mathrm{A}}$ receptors $\ldots \ldots \ldots \ldots \ldots \ldots \ldots \ldots \ldots \ldots 1$

II-4 Assessment of direct gating effects of meprobamate in

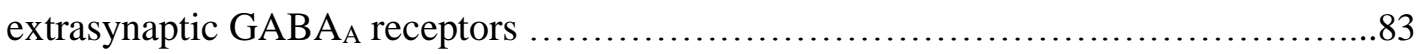

II-5 Assessment of allosteric effects of meprobamate

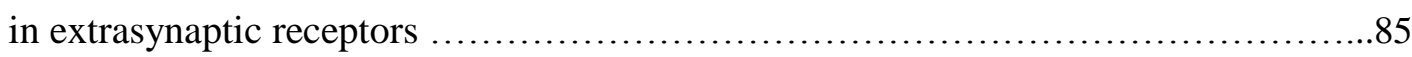

II-6 Potentiation of maximal GABA by meprobamate in

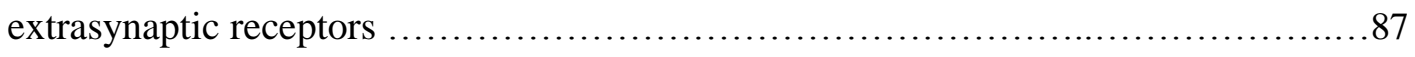

II-7 Assessment of "barbiturate-like" actions of meprobamate ......................89

III-1 Alignment of $\alpha 1$ and $\alpha 3$ domains of TM4 showing non-identical (red) and mutated $(*)$ amino acids .112

III-2 Influence of the alpha3 subunit TM4 mutations on direct 
activation by meprobamate

III-3 Influence of $\beta$-subunit TM2 T6'F Mutation on inhibitory

effects of carisoprodol 116

III-4 Influence of $\beta$-subunit TM2 T6'F Mutation on inhibitory

effect by pentobarbitol.

III-5 Influence of $\beta$-subunit TM2 T6'F Mutation on

allosteric modulation by MEP

IV-1 Chemical structure of meprobamate; 1,3 propanediol;

3-hydroxypropyl carbamate. 132 


\section{LIST OF ABBREVIATIONS}

GABA

GABAAR

LGIC

CSP

BZD

PTX

PB

CYP2C19

TM

HEK

CNS

DMSO

EGTA

HEPES $\gamma$-aminobutyric acid

$\gamma$-aminobutyric acid type A receptor

Ligand-gated ion channel

Carisoprodol

Benzodiazepines

Picrotoxin

Pentobarbital

Cytochrome P450 2C19 enzyme

Transmembrane

Human embryonic kidney

Central nervous system

Dimethyl sulfoxide

Ethylene glycol-bis ( $\square$-aminoethyl ether)

$\mathrm{N}$-2-hydroxyethylpiperazine-N-2-etanesulfonicacid N, N,

N', N'-tetra acetic acid 


\section{CHAPTER I \\ INTRODUCTION}

\section{MEPROBAMATE}

\section{History}

Meprobamate was the first drug to be marketed specifically as an anxiolytic drug, that is, capable of allaying anxiety and related conditions, without inducing sedation or sleep. Development of meprobamate is attributed to some serendipitous observations during the course of development of new preservatives, after discovery of penicillin. During the course of a search for compound to prevent enzymatic destruction of penicillin by penicillinase producing gram-negative bacteria, normally present in the air, a compound mephenesin was found to have reversible tranquilizing and muscle relaxing properties (Berger et al., 1946). Although later a powder form of penicillin made obsolete the use of preservatives, some interesting properties observed with these $\alpha$-substituted esters of glycerol, created a lot of attention. As stated earlier, mephenesin possessed tranquilizing and at high doses, sedative and muscle relaxant properties. Initial excitatory effect, associated with barbiturate use was absent, showing a lack of central action. For the muscle relaxant properties, diaphragm muscle was last to get affected, causing the respiratory paralysis to appear last as a lethal side effect and at a very high dose. There was a large gap between dose for paralysis of other muscles and diaphragmatic muscle (Berger, 1947). However, curare, a widely used muscle relaxant of the day as an adjuvant to anesthetics, had respiratory paralysis as a major side effect (Delahanty et al., 2011; Chen et al., 2014). In addition, mephenesin possessed a unique anticonvulsant action. Strychnine-induced convulsions (convulsions induced via actions at spinal cord) were inhibited by tranquilizing doses of mephenesin while hexobarbitone, a barbiturate, was unable to prevent these. Leptazol induced convulsions (convulsions induced via actions on midbrain), were 
inhibited by hexobarbitone, but required a very high dose of mephenesin. Above effects show the effect of mephenesin at spinal cord level rather than at the midbrain level. This also explained the initial missing euphoric and exciting action associated with the use of mephenesin (associated with a central action), present with the use of barbiturates. However, its use as such was limited by its three major drawbacks — mephenesin was quickly metabolized to inactive products leading to a very short duration of action, greater effect on the spinal cord than on supra-spinal structures and a weak action, so large doses were required (Berger, 1947). Mephenesin was quickly metabolized via oxidation of its terminal hydroxyl group leading to the formation of inactive metabolites. Blocking the oxidation of the terminal hydroxyl group would be a major mechanism for extended action of mephenesin. After some trial and error, carbamate esters of 1, 3-propane diols were prepared which had longer duration of action and stronger muscle relaxant properties. By the late 1950s meprobamate was the most widely prescribed drug in the United States and in many other countries. It retained its lead until diazepam, the second drug from the benzodiazepine series, was introduced into clinical use in late 1960 (Greenblatt et al., 1974).

Within 2 years of introduction of meprobamate, cases of its abuse and withdrawal after long term use were reported (Boyd et al., 1958). By 1970 it was listed as a controlled substance, in USA market, after it was discovered to cause physical and psychological dependence. While meprobamate was made a controlled substance, drugs metabolized to meprobamate are widely used and abused and are associated with serious side effects. One such drug carisoprodol, would be discussed in the later sections of this dissertation. 
Fig 1. Chemical structure of meprobamate and mephenesin 


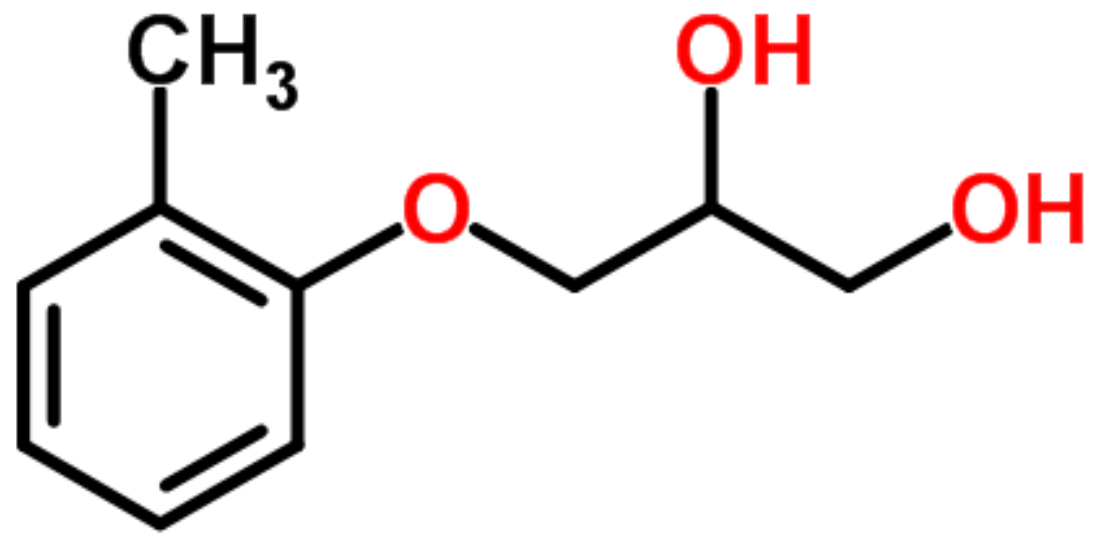

Mephenesin

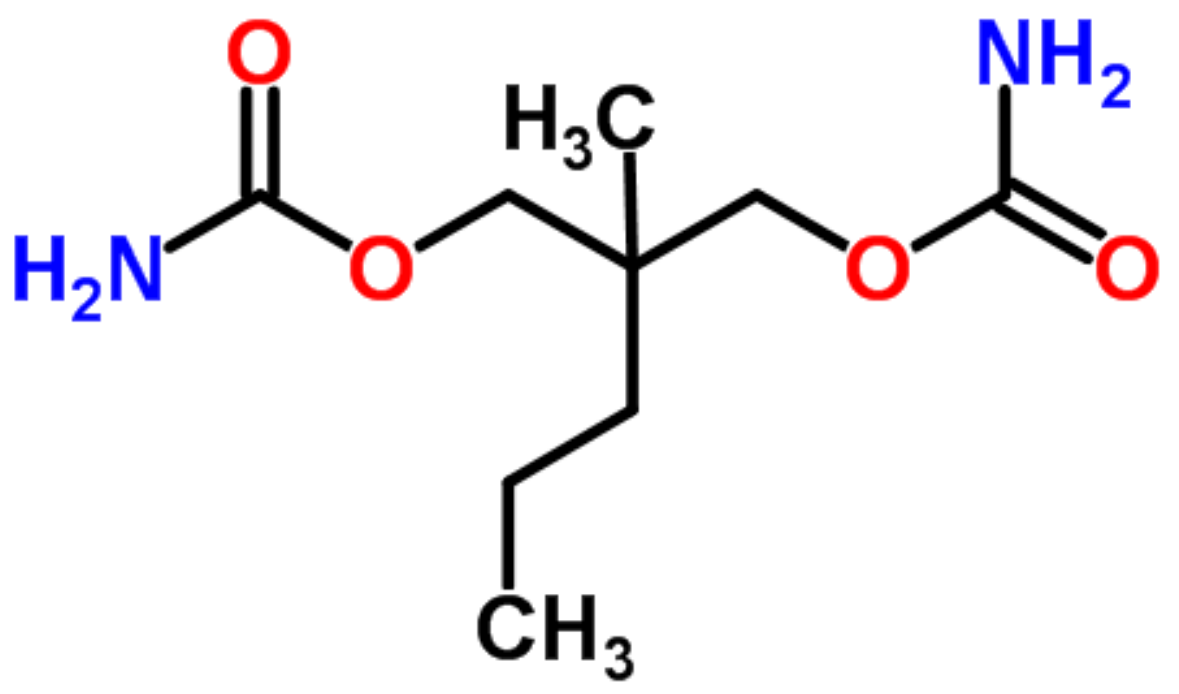

Meprobamate 


\section{Chemistry and Physiological Effects of Meprobamate}

Meprobamate (Miltown by wallace laboratories and Equanil by Wyeth Laboratories), chemically, is 2-methyl-2-npropyl- 1, 3-propanediol dicarbamate. First synthesized in 1950 by Ludwig and Piech (1951), meprobamate has the following physical properties: It is a white crystalline powder with a characteristic bitter taste and faint odor. It melts without decomposition at $104-106^{\circ} \mathrm{C}$. It is soluble in water to the extent of 0.34 per cent at $20^{\circ} \mathrm{C}$ and 0.79 per cent at $37^{\circ} \mathrm{C}$, but is readily soluble in most organic solvents. It is unaffected by dilute acid and alkali and thus is not broken down in gastric or intestinal juices (Berger, 1954).

Meprobamate when applied to mice, lead to a sedative action accompanied by loss of righting reflex. Unlike barbiturates, loss of righting reflex associated with the use of meprobamate is unaccompanied by any sign of excitability. Common signs of excitability like aimless running, arching and stretching of back and hind limbs, licking of paws, are present during induction of barbiturates, while absent even at paralyzing doses of meprobamate. Recovery is spontaneous and complete. Although mephenesin too had similar anesthetic action, meprobamate had longer periods of induction and duration and is also effective orally (Berger, 1954).

Monkeys exposed to $200 \mathrm{mg} / \mathrm{kg}$ meprobamate, calmed down and became easier to control. They became easier to pet and easily had their food. There were no signs of agitation or excitement. This stage lasted for 5-6 hours. At $400 \mathrm{mg} / \mathrm{kg}$ dose, there was a complete flaccid paralysis that lasted for 7 hours. At higher doses there was longer duration of action. Even at these higher doses respiration and heart beat were normal and the monkeys recovered almost completely without any immediate or later ill effects (Berger, 1954). 
Dogs exposed to high dose of meprobamate for a long duration (sub-acute, 60-75 days), did not show any hematological abnormality or abnormalities in kidney function tests. Autopsy reports also did not show ill effects in viscera of kidney, liver, stomach, small intestine, bladder or adrenal glands. Mice exposed to very high doses for a very long time period (chronic, 12-15 months) also did not show signs of toxicity, except for decreased weight gain (Berger, 1954).

Meprobamate was also effective in preventing pentylenetetrazole, strychnine and electroshock mediated convulsions and death in mice (Berger, 1954).

A search for separation of muscle relaxant properties of meprobamate with its tranquilizing properties led to invention of $\mathrm{N}$-isopropyl-2-methyl-npropyl-1,3-propanediol dicarbamate or carisoprodol which differed from meprobamate in having an iso-propyl group in place of hydrogen atom in one of the carbomyl nitrogens (Berger 1959). Although minor, the difference in structure produced surprisingly different pharmacological and functional properties in carisoprodol.

In electro encephalic recordings in cats and rabbits, meprobamate did not have any effect in brain wave patterns (Gangloff, 1959). Carisoprodol in similar doses, produced an increase in amplitude and a decrease in frequency in the cortical and sub cortical regions (Berger et al., 1960). The characteristic spindling of electro encephalic recordings of barbiturates was also missing with that of both carisoprodol and meprobamate. Larger doses of carisoprodol caused a progressive slowing of frequency and an increase in amplitude until $40-60 \mathrm{mg} / \mathrm{kg}$ dose. Still higher doses caused greatly reduced activity and longer stretches of electric silence (Berger et al., 1960). A remarkable property of carisoprodol, at lower doses (5 $-10 \mathrm{mg} / \mathrm{kg}$ ), as we see above is the changes in the brain wave pattern, unaccompanied by 
behavioral changes. In this respect carisoprodol resembled atropine, the anti-cholinergic agent, which also made changes in the brain wave pattern unaccompanied by behavioral changes (Longo, 1956; Bradley et al., 1957). However at higher doses, while carisoprodol caused muscle relaxation, paralysis and a generalized central nervous system depression, atropine lead to an excitement. On account of the above similarity, when carisoprodol was explored for peripheral anticholinergic actions, it was found to have none. Convulsions by convulsive discharges set up in limbic system by electric stimulation, were prevented by meprobamate, mephenesin and barbiturates, but not by carisoprodol. This was a strange finding considering more similarity in the structure of meprobamate and carisoprodol compared to meprobamate and mephenesin. This lack of action of carisoprodol in the limbic system fits with clinical finding of lack of tranquilising action with carisorpodol (Berger et al., 1960).

\section{Felbamate}

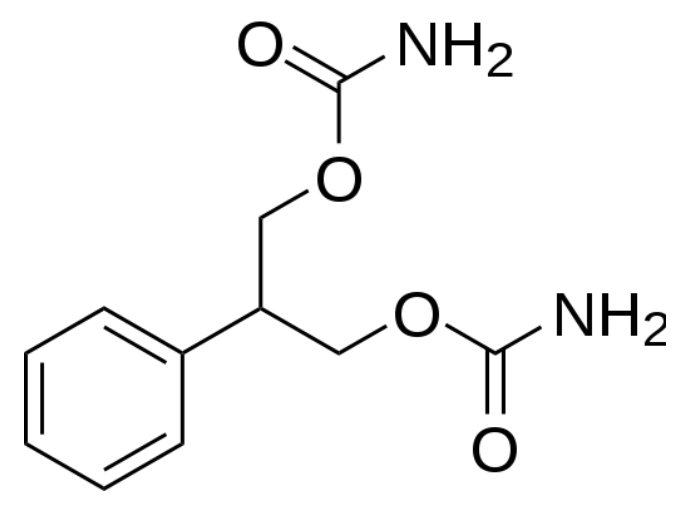

Felabamte (2-phenyl-1,3-propanediol dicarbamate) was prescribed as an anti-epileptic drug prescribed in adult (Absence seizure), and childhood epilepsy (Lenaux-Gastaut syndrome). However, fatal cases of aplastic anemia and hepatotoxicity has precluded its use as an anti-epileptic agent. Thus its use has been confined to refractory cased of epilepsy and 
Lenaux-gastaut syndrome. However recent clinical trials have shown it to be safe, well tolerated and effective in various types of epilepsy syndromes (Shah et al., 2016).

Felbamate has been known to act via activation of $\mathrm{GABA}_{\mathrm{A}}$ receptor and inhibition of NMDA receptors. The dual mechanism of action has been responsible for the broad spectrum anti-epileptic action (Rho et al., 1994). Meprobamate has also been known to have similar action on $\mathrm{GABA}_{\mathrm{A}}$ and NMDA receptors. But while meprobamate both directly gate and allosterically modulate $\mathrm{GABA}_{\mathrm{A}}$ receptors, felbamate has just direct gating action on $\mathrm{GABA}_{\mathrm{A}}$ receptor (Rho et al., 1997). Clinically, while felbamate is mildly sedating, broad spectrum antiepileptic agent, meprobamate has been shown to have a strong tranquilizing, sedating but weak anti-epileptic effect (Rho et al., 1997). A detailed subunit dependent effect of felbamate may explain the molecular basis for the differences in the clinical effects of the two drugs.

Most severe side effects of felbamate include aplastic anaemia and severe hepatotoxicity. Others include nausea, vomiting, insomnia, anorexia, dizziness and headache.

\section{Pharmacology and Metabolism of Meprobamate}

Meprobamate is used either alone or in combination with other common over-thecounter drugs like, diphenhydramine, acetylsalicylic acid or codeine. Meprobamate pharmacokinetics are unaffected by these commonly used combinations. However, diphenhydramine metabolism is affected by meprobamate. Bioavailability is similar for oral or rectal application (Gilbert et al., 1984).

After oral ingestion of a therapeutic dose, most of meprobamate is absorbed via GI tract and peak plasma levels are reached within 1 hour to 3 hours. Less than $10 \%$ of 
meprobamate was found in the feces (showing maximum absorption via GI tract). In studies using carbon labelled meprobamate, meprobamate started appearing in the urine within 30 minutes and by 24 hours most of it was excreted from the body (Walkeinstein et al 1958). Protein binding of meprobamate is negligibly small (14\%-24\%) and the volume of distribution (Vd) was reported to be $0.70 \mathrm{~L} / \mathrm{kg}$ and is not significantly altered in overdose (Verpooten et $a l ., 1982) .50 \%$ of amount of drug is unchanged meprobamate. Meprobamate is primarily metabolized to inactive metabolites by the liver, primary metabolite being hydroxylmeprobamate and $10 \%-20 \%$ of the parent compound is excreted by the kidneys (Bismuth et al., 1985). Elimination can be described by first-order pharmacokinetics and reported elimination half-lives range between 6.4 hours and 16.6 hours in therapeutic dose and were similar in overdose (Hollister et al., 1964; Maddock et al., 1967).

\section{Meprobamate Side effects, Abuse and Withdrawal}

Meprobamate was the first block-buster drug, selling billions of pills. It was supposed to be free of toxic side effects, abuse and dependence potential. A common side effect of meprobamate associated with regular use is allergic skin rashes, which appear in the form of urticaria or erythema. They have been found in as high as $1-2 \%$ of patients taking the drug (Hollister, 1957). Allergic rashes respond to drug withdrawal or concomitant use of antihistaminic medication. More severe form of skin reactions, like pustular skin lesions and purpura, have also been reported (Friedman et al., 1956; Holoubek et al., 1957). These promptly respond to discontinuation of the drug and corticosteroid therapy (Stroud, 1957). Other common side effects associated with meprobamate use include nausea, dizziness, drowsiness and fainting spells especially found when initial dose is more than $400 \mathrm{mg}$. An alcoholic patient with long term use of high dose of meprobamate showed a grand mal epilepsy 
upon withdrawal (Pennington, 1957). A case of death with aplastic anemia has also been reported with meprobamate use (Meyer et al., 1957).

Meprobamate was initially advertised as a non-addictive drug. Its good tranquilizing effect along with relatively good safety profile prompted it to be sold without a prescription. But many cases characteristic of a typical habit-forming drug were reported in the initial few years of use of the drug. Addiction or a habit formation to a drug, has the following characteristics: (1) an intense craving for the drug based on its euphoric effects, (2) tolerance build up, requiring increasingly larger doses to produce the same effect, and (3) withdrawal symptoms associated with sudden discontinuation of the drug (Lemere, 1956). An example include a patient with a history of alcohol and barbiturate abuse and suffering excessive anxiety at work, was prescribed meprobamate $400 \mathrm{mg} 3$ times a day. He had a good response, but had to consume increasing doses of the drug to sustain the same response. Sometimes it was 50-70 tablets a day. An attempt at quitting led to anxiety and tremor and a grand mal seizure after 20 hours. Upon admission he was stuporous, confused and anxious and suffered another grand mal seizure. He recovered after gradual weaning of the drug (Mohr et al., 1958). In another studiy, patients did not show dependence (physical or psychic) or withdrawal even after prolonged use of clinically effective dose (Boyd et al., 1958). So, other factors have been associated with the development of meprobamate addiction and dependence, which include amount of drug intake, previous history of drug abuse and personality of the patient. At the peak of its use, meprobamate had been implicated in $7 \%$ of self-poisoning cases (Allen et al., 1977).

Commonly known side effects of a meprobamate overdose include central nervous system (CNS) depression, weakness, clonus and hyperactive reflexes, tachycardia, hypotension and respiratory depression. Meprobamate also produces CNS-depressing 
symptoms (Bramness et al., 2005) . Meprobamate intoxication is often serious and sometimes fatal $(5 \%)$, resulting from hemodynamic disturbance and circulatory collapse, secondary to severe acute cardiac failure (Charron et al., 2005). In a case report, Lhoste et al., 1977, suggested a predominant cardiogenic mechanism responsible for such hemodynamic failure. The mechanism of cardiac toxicity is unknown. Patients with meprobamate poisoning were shown to have a low cardiogenic index, ejection fraction, high right atrial pressure and pulmonary capillary wedge pressure, showing a cardiogenic shock and thus a direct cardiac effect (Lhoste et al., 1977; Charron et al., 2005). In a case of fatal meprobamate poisoning, maximum meprobamate accumulation was found in heart, showing a possible direct cardio toxic effect (Kintz et al., 1988). Also, ionotropic drugs have been useful in such cases, showing presence of a cardiac depression (Lhoste et al., 1977; Taboulet et al., 1994). A related compound, felbamate, is protective in cerebral ischemia and hypoxia (Wallis et al., 1992) via a vasodilatory mechanism. Meprobamate, having a similar structure, may share some of this vasodilatory effect. In the case report of Lhoste et al. 1977, a patient with severe meprobamate poisoning had decreased peripheral resistance, unlikely in an isolated cardiogenic shock. Thus, meprobamate-mediated hypotension is due to dual mechanism of direct cardiac depression and peripheral vasodilatory effect.

An overdose of meprobamate also leads to an altered consciousness which corresponds to its plasma concentrations. Below $5 \mathrm{mg} / 100 \mathrm{ml}$, patients have been found to be awake. A non-serious coma occurs between 6-12 $\mathrm{mg} / 100 \mathrm{ml}$ and a deep coma is induced at concentrations greater than $10 \mathrm{mg} / 100 \mathrm{ml}$ (Maddock et al., 1967).

Recently, acute pancreatitis has also been reported as a possible effect of meprobamate poisoning (Fathallah et al., 2011). Possible mechanism is stasis due to hypovolemia leading to increased viscosity and thrombosis or a direct cellular toxicity (Underwood et al., 1993). 


\section{GABAA receptor}

GABA is the primary inhibitory neurotransmitter in the CNS (Bormann, 2000) with glycine, being the primary inhibitory neurotransmitter in the spinal cord (Betz et al., 1988; Moss et al., 2001). Primary excitatory neurotransmitter in the CNS is the glutamate (Meldrum, 2000). GABA is synthesized from glutamate in a one step process by enzyme, L-glutamic acid decarboxylase (GAD). Thus along with itself working as a neurotransmitter and a co-factor for folic acid and hormone TSH (Thyrotropin releasing hormone), glutamate is used for the synthesis of GABA (Erlander et al., 1991)(figure 1).

GABA receptors are of 3 types: $\mathrm{GABA}_{\mathrm{A}}, \mathrm{GABA}_{\mathrm{B}}$ and $\mathrm{GABA}_{\mathrm{C}}$. Considering similar functional nature of $\mathrm{GABA}_{\mathrm{C}}$ receptor as $\mathrm{GABA}_{\mathrm{A}}$, they have been nominated as a part of $\mathrm{GABA}_{\mathrm{A}}$ receptor (Barnard et al., 1998). But there has been an accumulating evidence of a distinct structure, function, pharmacology and genetics which makes the case of a separate nomenclature (Bormann, 2000).

GABA interacts with $\mathrm{GABA}_{\mathrm{A}}$ receptors resulting in an opening of chloride channel leading to depolarization and inhibitory post synaptic potential (IPSP). In some cases GABA can be excitatory in nature. Example, in developing neurons, with high intracellular chloride concentrations, a GABA interaction leads to an outward chloride flow and generation of an excitatory post synaptic potential (EPSP) (Rivera et al., 1999). This phenomenon has a profound effect on survival and differentiation during neuronal development (Ben-Ari et al., 1997; Belhage et al., 1998). 
Figure 2: Features of a GABA Synapse. 
Synaptic receptors

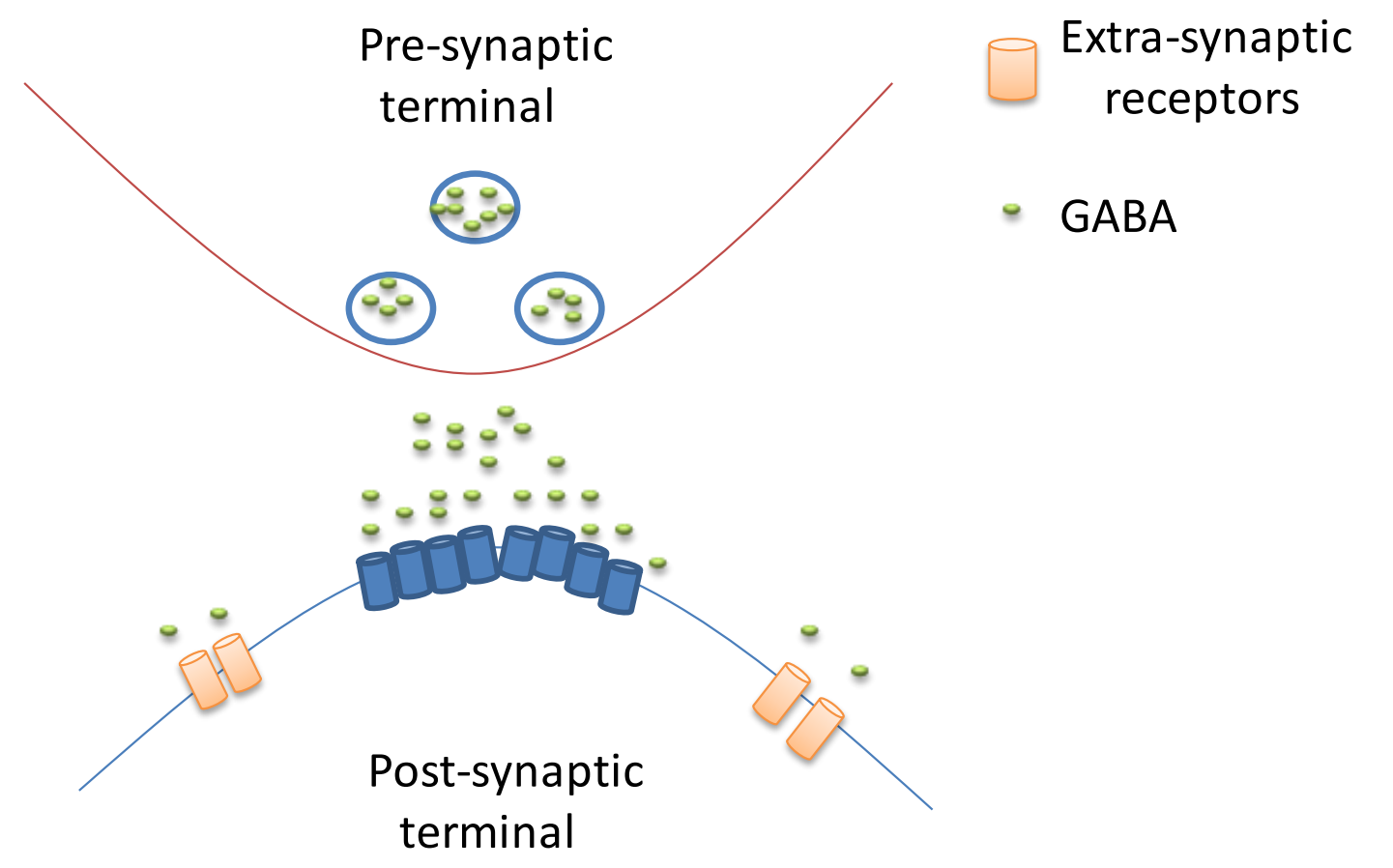


$\mathrm{GABA}_{\mathrm{A}}$ receptors are members of cys-loop ligand-gated ion channels. Cys-loop is a characteristic loop formed by a disulfide bond between two cysteine (Cys) residues which are 13 highly conserved amino acids apart near the N-terminal extracellular domain of the alpha subunit. Common members of this group are nicotinic acetylcholine receptors, $\mathrm{Zn}^{++}$receptors, type 3 serotonin $\left(5 \mathrm{HT}_{3}\right)$ receptors, glycine and $\mathrm{GABA}_{\mathrm{C}}$ receptors (Schofield et al., 1987; Connolly et al., 2004). GABA receptors are sensitive to bicuculline (Bormann, 1988; Bormann, 2000) $\mathrm{GABA}_{\mathrm{A}}$ receptors are sites for many ligands like benzodiazepines, barbiturates, alcohol, anesthetics and muscle relaxants like carisoprodol and meprobamate (Akaike et al., 1985; Orser et al., 1994; Sigel et al., 1997; Kumar et al., 2015). GABA receptors are metabotropic $\mathrm{G}$ protein-coupled receptors sensitive to baclofen (Bormann, 1988; Bowery, 1989; Marshall et al., 1999). They mediate their effect via signal transduction pathways (Couve et al., 2000). Located on the presynaptic membrane, they inhibit the release of inhibitory GABA in synaptic terminal. So overall having an excitatory effect. GABA $\mathrm{B}$ as a therapeutic target has been less exploited (Bowery, 1989; Marshall et al., 1999). A different type of receptor not sensitive to bicuculline or baclofen, previously known as GABAC receptors (Johnston, 1996), are sensitive to GABA and the GABA analogue, aminocaproic acid. They are also ligand-gated ion channel, composed of $\rho$-subunits, with the opening of chloride channel on activation by GABA (Bormann et al., 1995; Johnston, 1996). However, they are more sensitive and have a very weak desensitization. GABAC receptors are normally located in the bipolar cells of retina (Shimada et al., 1992). As stated earlier, GABAC has unique pharmacology compared to $\mathrm{GABA}_{\mathrm{A}}$ receptor. It is insensitive to bicuculline and baclofen (Johnston, 1996). However $\rho 1$-homomeric $\mathrm{GABA}_{\mathrm{C}}$ receptors were inhibited by picrotoxin like 
$\mathrm{GABA}_{\mathrm{A}}$, while the $\rho 2$-homomeric or $\rho 1 \rho 2$ were not inhibited by picrotoxin (Cutting et al., 1991; Enz et al., 1998; Feigenspan et al., 1998; Enz et al., 1999).

\section{Structure of GABAA receptor and subunits classes and roles}

$\mathrm{GABA}_{\mathrm{A}}$ receptor is a member of cys-loop ligand gated ion channels. Much has been learned about the structure of of pentameric LGICs by solving of crystal structure of acetylcholine binding protein (AchBP) (Brejc et al., 2001). Recently structure of $\mathrm{GABA}_{\mathrm{A}}$ receptor itself has been solved (Miller et al., 2014). Cys loop ligand-gated ion channels are pentameric in nature, i.e., each ion channel consists of 5 subunits (Toyoshima et al., 1990; Nayeem et al., 1994). Each subunit consists of long extracellular $\mathrm{N}$ terminal domain, a short extracellular c terminal domain, four trans-membrane (TM1-TM4) domains and connecting loops. Connecting loops are short intracellular TM1-TM2 and a long intracellular TM3-TM4. There is also a short extra-cellular TM2-TM3 connecting loop (Schofield et al., 1987; Unwin, 1993). Five of these subunits come together to form pentameric ion channel. The TM2 domain of all the five subunit form the pore of the channel (Unwin, 1993; Xu et al., 1996). Extracellular TM2-TM3 play an important part in channel gating, i.e., carrying information after binding of ligand, leading to channel opening (Miyazawa et al., 2003; Thompson et al., 2010).

Above receptors were isolated using benzodiazepine affinity chromatography leading to partial sequencing and cloning of two receptor genes. cDNAs for the two polypeptides formed receptors with GABA activated current in Xenopus oocytes and these were designated as $\alpha$ and $\beta$ (Mohler et al., 1980; Schoch et al., 1985; Schofield et al., 1987; Sieghart, 1995).

These were used as probes to identify other subunits. Those with maximum homology (70-80\%) were assigned the same Greek letter and those with less homology (15-40\%) were 
assigned different Greek letter. Thus so far the following $\mathrm{GABA}_{\mathrm{A}}$ receptor subunits have been identified. $\alpha 1-6, \beta 1-3, \gamma 1-3, \delta, \theta, \varepsilon, \pi$ and $\rho 1-3$ (Lynch et al., 1995; Lynch et al., 1997; Siegwart et al., 2002). Some splice variants have also been identified. For example, the $\gamma 2$ has a short and a long form differing in the 8 amino acid insert in the intracellular (Whiting et al., 1990). Similarly a short and a long form splice variant have also been identified for $\beta 2$-subunit (McKinley et al., 1995) .

So the above subunits assemble together to form hetero-pentameric, chloride permeable channel. Out of the many possibilities of combinations, most common $\mathrm{GABA}_{\mathrm{A}}$ receptor expressed in brain is $2 \alpha, 2 \beta$ and one $\gamma$ stoichiometry with the $\gamma$ subunit, being able to be replaced by $\delta, \theta, \pi$ or $\varepsilon$ subunit (Im et al., 1995; Chang et al., 1996; Tretter et al., 1997; Baumann et al., 2001; Olsen et al., 2008). Out of all possible combinations, $\alpha 1 \beta 2 \gamma 2$ is most abundant with approximately $60 \%$ of the total $\mathrm{GABA}_{\mathrm{A}}$ receptor population. Distribution of other combinations are $\alpha 2 \beta 3 \gamma 2,15-20 \% ; \alpha 3 \beta \mathrm{n} \gamma 2,10-15 \% ; \alpha 4 \beta \mathrm{n} \gamma 2$ or $\alpha 4 \beta \mathrm{n} \delta, 5 \% ; \alpha 5 \beta 2 \gamma 2,<$ $5 \% ; \alpha 6 \beta 2 / 3 \gamma 2,<5 \%$ (Fritschy et al., 1995). Some GABA A $_{\mathrm{A}}$ receptor have two different $\alpha$ subunits. In recombinant receptors, the $\alpha$-subunit adjacent to the $\gamma 2$-subunit determines the sensitivity to the BZDs (Benke et al., 2004). Binding of GABA occurs at the interface of the $\alpha$ and $\beta$-subunits (Baumann et al., 2003) while benzodiazepines bind at the interface of $\alpha$ and $\gamma$ subunits (Sigel et al., 1997), leading to influx of chloride ions and generation of IPSP.

Functional roles of various subunits have been assessed using histidine to arginine point mutations at a conserved residue. In $\alpha 1, \alpha 2, \alpha 3$ or $\alpha 5$ subunit, this mutation abolish the binding of diazepam, whereas action of GABA is preserved (Rudolph et al., 1999; McKernan et al., 2000; Crestani et al., 2002; van Rijnsoever et al., 2004). The positions are, $\alpha 1 \mathrm{H} 101 \mathrm{R}$, $\alpha 2 \mathrm{H} 101 \mathrm{R}, \alpha 3 \mathrm{H} 126 \mathrm{R}, \alpha 5 \mathrm{H} 105 \mathrm{R}$. 
From the above mutation, it was assessed that $\alpha 1$ subunit-containing GABAA receptors mediate sedative, partly anti-convulsant and anterograde amnestic action (Rudolph et al., 1999); $\alpha 2$ subunit containing GABAA receptors mediate anxiolytic and myorelaxant actions (large portion of it) (Low et al., 2000; Crestani et al., 2001); rest of myorelaxant action

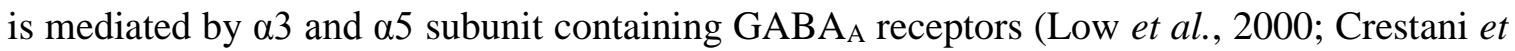
al., 2001; Crestani et al., 2002); $\alpha 5$-containing $\mathrm{GABA}_{\mathrm{A}}$ receptor further mediate tolerance to sedative action (van Rijnsoever et al., 2004); and addictive property $\alpha 1$-containing $\mathrm{GABA}_{\mathrm{A}}$ receptors (Tan et al., 2010).

$\beta$-subunit also has important implications in health and disease. $\beta 3$ subunit has been associated with schizophrenia (Huang et al., 2014), genetic epilepsies (Macdonald et al., 2010), autism (Delahanty et al., 2011), cleft palate (Inoue et al., 2008) as well as substance abuse (Chen et al., 2014). Angelman syndrome, associated with mental disorders and developmental delay and gait ataxia, is associated with the deletion of $\mathrm{GABA}_{\mathrm{A}}$ receptor $\beta 3$ subunit (Williams et al., 1995; DeLorey et al., 1998). In PTSD, a heterogenicty of $\beta 3 \mathrm{GABA}_{\mathrm{A}}$ receptor is associated with higher degree of anxiety insomnia and social dysfunction than a homozygocity (Feusner et al., 2001).

\section{Various modes of GABAA receptor activation}

$\mathrm{GABA}_{\mathrm{A}}$ receptor synaptic communication transmits a pre-synaptic signal. Depolarization following an action potential, lead to a calcium influx. Calcium causes synaptic vesicles to fuse with the presynaptic membrane. Each vesicle release thousands of GABA molecules, leading to a concentration in milli-molar range in the synaptic cleft. Some postsynaptic receptors exposed to GABA, have synchronous activation, leading to a phasic current (Edwards et al., 1990; Mody et al., 1994; Nusser et al., 1997; Brickley et al., 1999). Synaptic 
$\mathrm{GABA}_{\mathrm{A}}$ receptors that mediate phasic currents are made up of mostly $\alpha 1-3, \beta$ and $\gamma$ subunits (Rudolph et al., 2004). Phasic currents are characterized by fast activation, fast desensitization and fast deactivation. One the other hand there is a tonic current mediated by highly sensitive extrasynaptic-GABA $\mathrm{A}_{\mathrm{A}}$ receptors, characterized by slow desensitization which can also open spontaneously in absence of GABA (Brown et al., 2002; Tang et al., 2010; Wlodarczyk et al., 2013). Extrasynaptic $\mathrm{GABA}_{\mathrm{A}}$ receptors are $\delta$-containing (with mostly $\alpha 1, \alpha 4$ or $\alpha 6$ ) or $\gamma$ subunit with $\alpha 5$ (Fritschy et al., 1998; Brunig et al., 2002). $\delta$ subunit expressing receptors are characterized by many remarkable properties. As stated earlier, they generate a tonic current which are important component of CNS inhibition (Maguire et al., 2009; Bonin et al., 2011; Sarkar et al., 2011). They regulate behaviors like memory and anxiety (Whissell et al., 2013; Cushman et al., 2014; Lee et al., 2014; Paydar et al., 2014). They have a remarkable property of different expression levels under different physiological and pathological conditions. Neurosteroids mediate a stress-induced increase in expression of $\alpha 4 \beta \delta \mathrm{GABA}_{\mathrm{A}}$ receptors (Maguire et al., 2005; Shen et al., 2005). Since these receptors constrain memory, their upregulation in hippocampus may lead to stress-induced memory impairment. During pregnancy, stimulation by steroid hormones cause upregulation of $\delta$ subunit (Smith et al., 2006; Maguire et al., 2008). A partial or complete rebound following pregnancy may be responsible for post-partum depression and abnormal maternal behavior which responds to pharmacologically increasing delta activity. Expression of $\delta$ subunit and $\alpha 4$ subunit is reduced in pre-frontal cortex (of suicide victims) in depression (Merali et al., 2004). $\delta$-Expression is reduced in schizophrenia (Hashimoto et al., 2008b; Hashimoto et al., 2008a; MaldonadoAviles et al., 2009) and an upregulation is observed in cases of stroke and traumatic brain injury (Clarkson et al., 2010; Mtchedlishvili et al., 2010; Kharlamov et al., 2011). An expression of $\delta$ subunit in various brain regions and its functional role is stated in figure 4 . So $\delta$ subunit expressing receptors have important physiological and pathological implications. 
Figure 3: Representation of GABAA receptors. A, GABAA receptor subunit consists of long N-terminal domain, short C-terminal domain, 4 transmembrane (TM1-TM4) domain and long intracellular TM3-TM4 loop. B, 5 of the subunits assemble to form a pentameric cys loop ligand gated ion channel with GABA binding site between $\alpha$ and $\beta$-subunit and benzodiazepine binding site between $\alpha$ and $\gamma$-subunit. Note, in recombinant receptors, the $\alpha$-subunit adjacent to the $\gamma$-subunit determine the sensitivity to the benzodiazepines. $\mathbf{C}$, synaptic and extrasynaptic GABAA receptors composed of $\alpha 1-3, \beta, \gamma$ and $\alpha 4-\alpha 6, \beta$, $\delta$ respectively. $\alpha 5 \beta \gamma$ also form extrasynaptic GABAA receptors. 
a

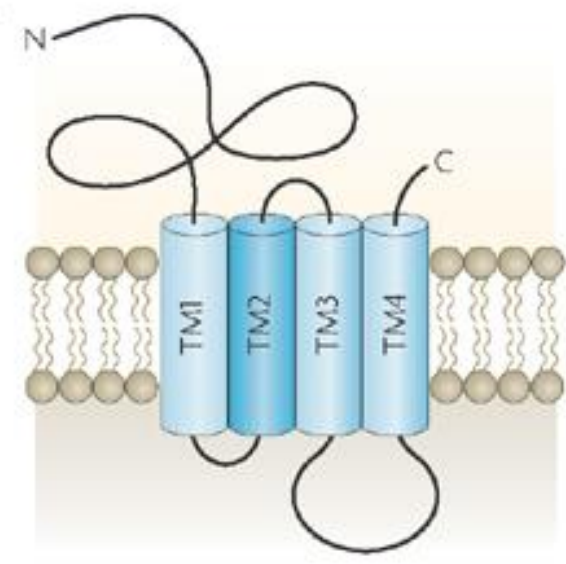

b

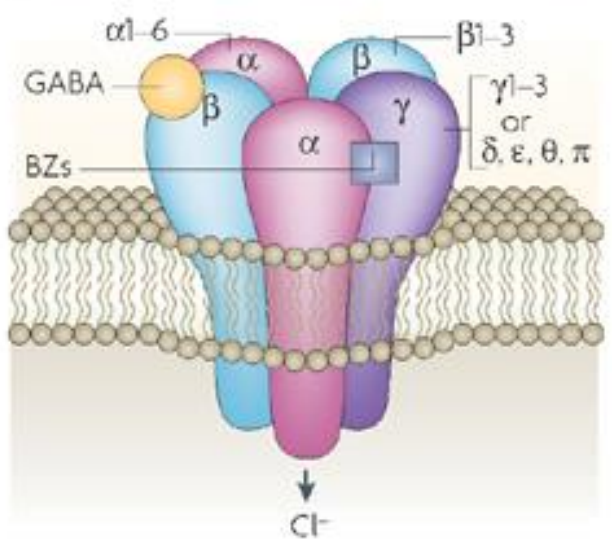

c

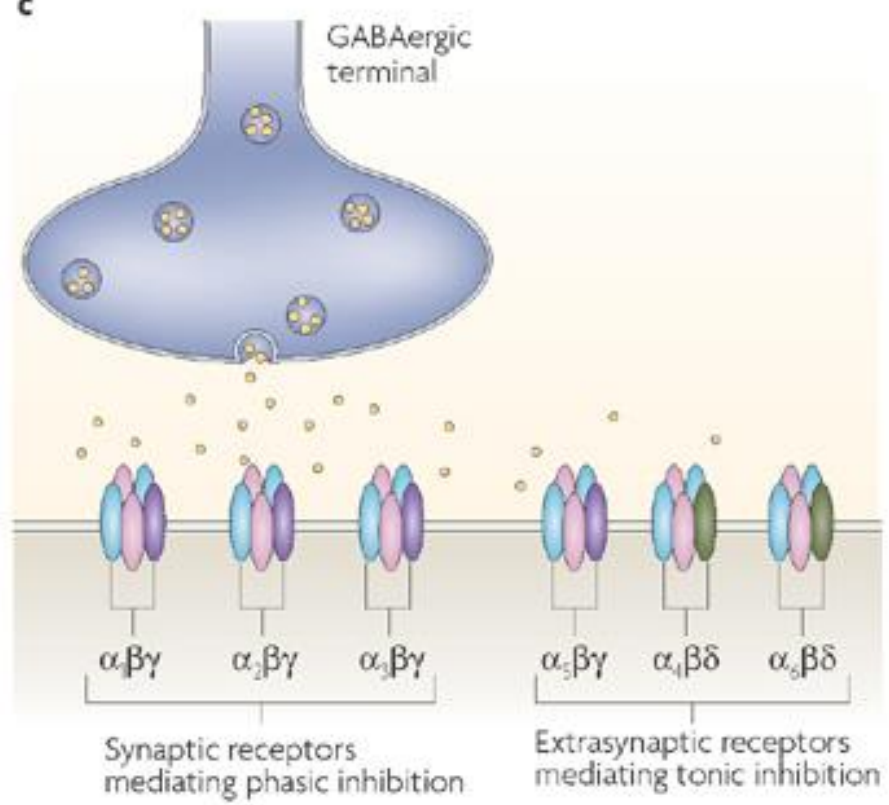

Nature neurosciences 
Figure 4: Delta GABAA expression and function in CNS. Red show a high expression level while orange a medium and yellow low level of expression. Probable functions are stated in boxes. 


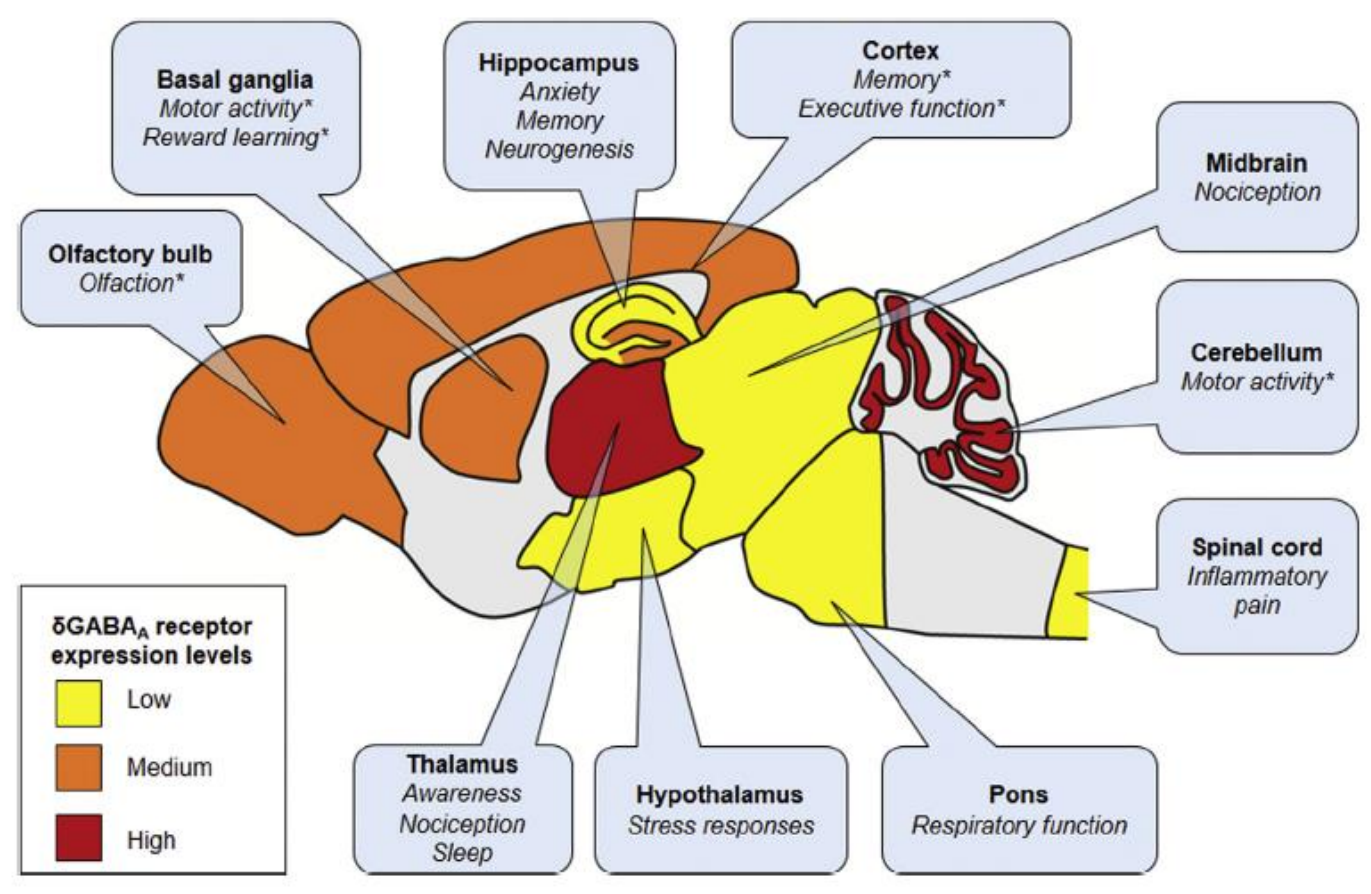

Whissell et al. 2014 


\section{Pharmacology of GABAA receptors}

Ligands have various modes of action on $\mathrm{GABA}_{\mathrm{A}}$ receptors. These include direct activation, allosteric modulation, inverse agonism and antagonism. Direct activation involves activation of receptor in the absence of GABA via the GABA site or a different site. Common ligands capable of direct activation are barbiturates, common tranqilizers and muscle relaxants like carisoprodol (Kumar et al., 2015) and meprobamate (Kumar et al. 2015, accepted pending revision). Ligands capable of direct activation at all the $\alpha$ subunits are commonly associated with fatal complications (Rho et al., 1997; Fass, 2010). Allosteric modulation is effect of a ligand on GABA mediated current via a different binding site. Common ligands capable of allosteric modulation are benzodiazepines and barbiturates (Hunkeler et al., 1981). Barbiturates, carisoprodol and meprobamate are capable of both direct action and allosteric modulation whereas benzodiazepines do not have a direct gating effect at $\mathrm{GABA}_{\mathrm{A}}$ receptors. An inverse agonist is a ligand having an effect opposite to that of an agonist (Braestrup et al., 1982; Bonetti et al., 1988). Antagonists do not have effects on their own on the receptor but block current by both the agonists and the inverse agonists. Common antagonists at $\mathrm{GABA}_{\mathrm{A}}$ receptors are picrotoxin and bicuculline (Bormann, 2000). Common antagonist at the benzodiazepine site on $\mathrm{GABA}_{\mathrm{A}}$ receptor is flumazenil (Hunkeler et al., 1981). 


\section{Aims of the study}

So, the main aim of this study is to understand a detailed mechanism of action of meprobamate on the various subunits of $\mathrm{GABA}_{\mathrm{A}}$ receptors. To understand whether meprobamate has a direct gating, allosteric modulatory or inhibitory effects on $\mathrm{GABA}_{\mathrm{A}}$ receptors. Meprobamate, though earlier was widely prescribed and later controlled, is the major metabolite of currently widely prescribed muscle relaxant, carisoprodol. Carisoprodol has direct gating, allosteric modulatory and inhibitory actions on $\mathrm{GABA}_{\mathrm{A}}$ receptor subunits. We wanted to test the hypothesis that meprobamate also has similar actions on $\mathrm{GABA}_{\mathrm{A}}$ receptors and the difference attributed to the difference in the structure of the two ligands. Carisoprodol has an isopropyl group that is absent in meprobamate.

Mechanism of action of meprobamate, known so far, is its action on $\mathrm{GABA}_{\mathrm{A}}$ receptor in a barbiturate like manner. So, we also wanted to test how similar and different is the action of meprobamate to barbiturates, represented in our studies by pentobarbital.

We further set out to explore the specific amino acids and domains responsible for the various modes of action of meprobamate on $\mathrm{GABA}_{\mathrm{A}}$ receptors. To summarize, the aims of study are as follows:

AIM 1: To determine the degree to which the lack of the isopropyl group may alter potency, efficacy and subunit preferring effect of meprobamate compared to CSP

AIM 2: To determine the extent to which actions overlap between meprobamate and barbiturate pentobarb 


\section{References:}

Akaike N, Oomura Y (1985). Interactions of gamma-aminobutyric acid (GABA), pentobarbital, and homopantothenic acid (HOPA) on internally perfused frog sensory neurons. Cell Mol Neurobiol 5: 245-255.

Allen MD, Greenblatt DJ, Noel BJ (1977). Meprobamate overdosage: a continuing problem. Clin Toxicol 11: 501-515.

Barnard EA, Skolnick P, Olsen RW, Mohler H, Sieghart W, Biggio G, et al. (1998). International Union of Pharmacology. XV. Subtypes of gamma-aminobutyric acidA receptors: classification on the basis of subunit structure and receptor function. Pharmacol Rev 50(2): 291-313.

Baumann SW, Baur R, Sigel E (2001). Subunit arrangement of gamma-aminobutyric acid type A receptors. J Biol Chem 276: 36275-36280.

Baumann SW, Baur R, Sigel E (2003). Individual properties of the two functional agonist sites in GABA(A) receptors. J Neurosci 23: 11158-11166.

Belhage B, Hansen GH, Elster L, Schousboe A (1998). Effects of gamma-aminobutyric acid (GABA) on synaptogenesis and synaptic function. Perspect Dev Neurobiol 5: 235-246. 
Ben-Ari Y, Khazipov R, Leinekugel X, Caillard O, Gaiarsa JL (1997). GABAA, NMDA and AMPA receptors: a developmentally regulated 'menage a trois'. Trends Neurosci 20: 523-529.

Benke D, Fakitsas P, Roggenmoser C, Michel C, Rudolph U, Mohler H (2004). Analysis of the presence and abundance of GABAA receptors containing two different types of alpha subunits in murine brain using point-mutated alpha subunits. J Biol Chem 279: 43654-43660.

Berger FM (1947). The mode of action of myanesin. Br J Pharmacol Chemother 2: 241-250.

Berger FM (1954). The pharmacological properties of 2-methyl-2-n-propyl-1,3-propanediol dicarbamate (miltown), a new interneuronal blocking agent. J Pharmacol Exp Ther 112: 413423.

Berger FM, Bradley W (1946). The pharmacological properties of alpha:beta-dihydroxygamma-(2-methylphenoxy)-propane (myanesin). Br J Pharmacol Chemother 1: 265-272.

Berger FM, Kletzkin M, Ludwig BJ, Margolin S (1960). The history, chemistry, and pharmacology of carisoprodol. Ann N Y Acad Sci 86: 90-107.

Betz H, Becker CM (1988). The mammalian glycine receptor: biology and structure of a neuronal chloride channel protein. Neurochem Int 13: 137-146. 
Bismuth C, Baud FJ, Galliot M, du Fretay XH, de Kerviller E (1985). [Liver metabolism of meprobamate: clinical estimation in acute intoxication]. J Toxicol Clin Exp 5: 321-328.

Bonetti EP, Burkard WP, Gabl M, Hunkeler W, Lorez HP, Martin JR, et al. (1988). Ro 154513: partial inverse agonism at the BZR and interaction with ethanol. Pharmacol Biochem Behav 31: 733-749.

Bonin RP, Labrakakis C, Eng DG, Whissell PD, De Koninck Y, Orser BA (2011). Pharmacological enhancement of delta-subunit-containing $\mathrm{GABA}(\mathrm{A})$ receptors that generate a tonic inhibitory conductance in spinal neurons attenuates acute nociception in mice. Pain 152: $1317-1326$.

Bormann J (1988). Electrophysiology of GABAA and GABAB receptor subtypes. Trends Neurosci 11: 112-116.

Bormann J (2000). The 'ABC' of GABA receptors. Trends Pharmacol Sci 21: 16-19.

Bormann J, Feigenspan A (1995). GABAC receptors. Trends Neurosci 18: 515-519.

Bowery $N$ (1989). GABAB receptors and their significance in mammalian pharmacology. Trends Pharmacol Sci 10: 401-407. 
Boyd LJ, Cammer L, Mulinos MG, Huppert VF, Hammer H (1958). Meprobamate addiction. J Am Med Assoc 168: 1839-1843.

Bradley PB, Elkes J (1957). The effects of some drugs on the electrical activity of the brain. Brain 80: 77-117.

Braestrup C, Schmiechen R, Neef G, Nielsen M, Petersen EN (1982). Interaction of convulsive ligands with benzodiazepine receptors. Science 216: 1241-1243.

Bramness JG, Morland J, Sorlid HK, Rudberg N, Jacobsen D (2005). Carisoprodol intoxications and serotonergic features. Clin Toxicol (Phila) 43: 39-45.

Brejc K, van Dijk WJ, Klaassen RV, Schuurmans M, van Der Oost J, Smit AB, et al. (2001). Crystal structure of an ACh-binding protein reveals the ligand-binding domain of nicotinic receptors. Nature 411: 269-276.

Brickley SG, Cull-Candy SG, Farrant M (1999). Single-channel properties of synaptic and extrasynaptic GABAA receptors suggest differential targeting of receptor subtypes. $J$ Neurosci 19: 2960-2973. 
Brown N, Kerby J, Bonnert TP, Whiting PJ, Wafford KA (2002). Pharmacological characterization of a novel cell line expressing human alpha(4)beta(3)delta GABA(A) receptors. Br J Pharmacol 136: 965-974.

Brunig I, Scotti E, Sidler C, Fritschy JM (2002). Intact sorting, targeting, and clustering of gamma-aminobutyric acid A receptor subtypes in hippocampal neurons in vitro. J Comp Neurol 443: 43-55.

Chang Y, Wang R, Barot S, Weiss DS (1996). Stoichiometry of a recombinant GABAA receptor. J Neurosci 16: 5415-5424.

Charron C, Mekontso-Dessap A, Chergui K, Rabiller A, Jardin F, Vieillard-Baron A (2005). Incidence, causes and prognosis of hypotension related to meprobamate poisoning. Intensive Care Med 31: 1582-1586.

Chen CH, Huang CC, Liao DL (2014). Association analysis of GABRB3 promoter variants with heroin dependence. PLoS One 9: e102227.

Clarkson AN, Huang BS, Macisaac SE, Mody I, Carmichael ST (2010). Reducing excessive GABA-mediated tonic inhibition promotes functional recovery after stroke. Nature 468: 305309. 
Connolly CN, Wafford KA (2004). The Cys-loop superfamily of ligand-gated ion channels: the impact of receptor structure on function. Biochem Soc Trans 32: 529-534.

Couve A, Moss SJ, Pangalos MN (2000). GABAB receptors: a new paradigm in G protein signaling. Mol Cell Neurosci 16: 296-312.

Crestani F, Low K, Keist R, Mandelli M, Mohler H, Rudolph U (2001). Molecular targets for the myorelaxant action of diazepam. Mol Pharmacol 59: 442-445.

Crestani F, Keist R, Fritschy JM, Benke D, Vogt K, Prut L, et al. (2002). Trace fear conditioning involves hippocampal alpha5 GABA(A) receptors. Proc Natl Acad Sci U S A 99: $8980-8985$.

Cushman JD, Moore MD, Olsen RW, Fanselow MS (2014). The role of the delta GABA(A) receptor in ovarian cycle-linked changes in hippocampus-dependent learning and memory. Neurochem Res 39: 1140-1146.

Cutting GR, Lu L, O'Hara BF, Kasch LM, Montrose-Rafizadeh C, Donovan DM, et al. (1991). Cloning of the gamma-aminobutyric acid (GABA) rho 1 cDNA: a GABA receptor subunit highly expressed in the retina. Proc Natl Acad Sci U S A 88: 2673-2677. 
Delahanty RJ, Kang JQ, Brune CW, Kistner EO, Courchesne E, Cox NJ, et al. (2011). Maternal transmission of a rare GABRB3 signal peptide variant is associated with autism. Mol Psychiatry 16: 86-96.

DeLorey TM, Olsen RW (1992). Gamma-aminobutyric acidA receptor structure and function. J Biol Chem 267: 16747-16750.

DeLorey TM, Handforth A, Anagnostaras SG, Homanics GE, Minassian BA, Asatourian A, et al. (1998). Mice lacking the beta3 subunit of the GABAA receptor have the epilepsy phenotype and many of the behavioral characteristics of Angelman syndrome. J Neurosci 18: 8505-8514.

Edwards FA, Konnerth A, Sakmann B (1990). Quantal analysis of inhibitory synaptic transmission in the dentate gyrus of rat hippocampal slices: a patch-clamp study. $J$ Physiol 430 : 213-249.

Enz R, Cutting GR (1998). Molecular composition of GABAC receptors. Vision Res 38: 14311441.

Enz R, Cutting GR (1999). GABAC receptor rho subunits are heterogeneously expressed in the human CNS and form homo- and heterooligomers with distinct physical properties. Eur J Neurosci 11: 41-50. 
Erlander MG, Tobin AJ (1991). The structural and functional heterogeneity of glutamic acid decarboxylase: a review. Neurochem Res 16: 215-226.

Fass JA (2010). Carisoprodol legal status and patterns of abuse. Ann Pharmacother 44: 19621967.

Fathallah N, Zamy M, Slim R, Fain O, Hmouda H, Bouraoui K, et al. (2011). Acute pancreatitis in the course of meprobamate poisoning. JOP 12: 404-406.

Feigenspan A, Bormann J (1998). GABA-gated Cl- channels in the rat retina. Prog Retin Eye Res 17: 99-126.

Feusner J, Ritchie T, Lawford B, Young RM, Kann B, Noble EP (2001). GABA(A) receptor beta 3 subunit gene and psychiatric morbidity in a post-traumatic stress disorder population. Psychiatry Res 104: 109-117.

Friedman HT, Marmelzat WL (1956). Adverse reactions to meprobamate. J Am Med Assoc 162: 628-630. 
Fritschy JM, Mohler H (1995). GABAA-receptor heterogeneity in the adult rat brain: differential regional and cellular distribution of seven major subunits. J Comp Neurol 359: 154194.

Fritschy JM, Johnson DK, Mohler H, Rudolph U (1998). Independent assembly and subcellular targeting of GABA(A)-receptor subtypes demonstrated in mouse hippocampal and olfactory neurons in vivo. Neurosci Lett 249: 99-102.

Gangloff H (1959). Effect of phenaglycodol and meprobamate on spontaneous brain activity, evoked EEG arousal and recruitment in the cat. $J$ Pharmacol Exp Ther 126: 30-40.

Gilbert JD, Aylott RI, Sogtrop HH, Draffan GH (1984). The pharmacokinetics of meprobamate following its oral and rectal administration as a series of combinations with diphenhydramine, acetylsalicylic acid, codeine and pentaerythritol tetranitrate. Arzneimittelforschung 34: 13231327.

Greenblatt DJ, Shader RI (1974). Drug therapy. Benzodiazepines (second of two parts). N Engl J Med 291: 1239-1243.

Hashimoto T, Bazmi HH, Mirnics K, Wu Q, Sampson AR, Lewis DA (2008a). Conserved regional patterns of GABA-related transcript expression in the neocortex of subjects with schizophrenia. Am J Psychiatry 165: 479-489. 
Hashimoto T, Arion D, Unger T, Maldonado-Aviles JG, Morris HM, Volk DW, et al. (2008b). Alterations in GABA-related transcriptome in the dorsolateral prefrontal cortex of subjects with schizophrenia. Mol Psychiatry 13: 147-161.

Hollister LE (1957). Complications from the use of tranquilizing drugs. N Engl J Med 257: 170-177.

Hollister LE, Levy G (1964). Kinetics of Meprobamate Elimination in Humans. Chemotherapy 9: 20-24.

Holoubek JE, Thomas OC, Segura J (1957). Toxic reaction to 2-methyl-2-n-propyl-1, 3, propanediol dicarbamate (miltown and equanil). Ann Intern Med 46: 1002-1004.

Huang CC, Cheng MC, Tsai HM, Lai CH, Chen CH (2014). Genetic analysis of GABRB3 at $15 q 12$ as a candidate gene of schizophrenia. Psychiatr Genet 24: 151-157.

Hunkeler W, Mohler H, Pieri L, Polc P, Bonetti EP, Cumin R, et al. (1981). Selective antagonists of benzodiazepines. Nature 290: 514-516. 
Im WB, Pregenzer JF, Binder JA, Dillon GH, Alberts GL (1995). Chloride channel expression with the tandem construct of alpha 6-beta 2 GABAA receptor subunit requires a monomeric subunit of alpha 6 or gamma 2. J Biol Chem 270: 26063-26066.

Inoue H, Kayano S, Aoki Y, Kure S, Yamada A, Hata A, et al. (2008). Association of the GABRB3 gene with nonsyndromic oral clefts. Cleft Palate Craniofac J 45: 261-266.

Johnston GA (1996). GABAc receptors: relatively simple transmitter -gated ion channels? Trends Pharmacol Sci 17: 319-323.

Kharlamov EA, Lepsveridze E, Meparishvili M, Solomonia RO, Lu B, Miller ER, et al. (2011). Alterations of $\mathrm{GABA}(\mathrm{A})$ and glutamate receptor subunits and heat shock protein in rat hippocampus following traumatic brain injury and in posttraumatic epilepsy. Epilepsy Res 95: 20-34.

Kintz P, Tracqui A, Mangin P, Lugnier AA (1988). Fatal meprobamate self-poisoning. Am J Forensic Med Pathol 9: 139-140.

Kumar M, Gonzalez LA, Dillon GH (2015). Assessment of subunit-dependent direct gating and allosteric modulatory effects of carisoprodol at GABAA receptors. Neuropharmacology 97: 414-425. 
Lee V, Sarkar J, Maguire J (2014). Loss of Gabrd in CRH neurons blunts the corticosterone response to stress and diminishes stress-related behaviors. Psychoneuroendocrinology 41: 7588.

Lemere F (1956). Habit-forming properties of meprobamate. AMA Arch Neurol Psychiatry 76: 205-206.

Lhoste F, Lemaire F, Rapin M (1977). Treatment of hypotension in meprobamate poisoning. N Engl J Med 296: 1004.

Longo VG (1956). Effects of scopolamine and atropine electroencephalographic and behavioral reactions due to hypothalamic stimulation. J Pharmacol Exp Ther 116: 198-208.

Low K, Crestani F, Keist R, Benke D, Brunig I, Benson JA, et al. (2000). Molecular and neuronal substrate for the selective attenuation of anxiety. Science 290: 131-134.

Lynch JW, Rajendra S, Barry PH, Schofield PR (1995). Mutations affecting the glycine receptor agonist transduction mechanism convert the competitive antagonist, picrotoxin, into an allosteric potentiator. J Biol Chem 270: 13799-13806. 
Lynch JW, Rajendra S, Pierce KD, Handford CA, Barry PH, Schofield PR (1997). Identification of intracellular and extracellular domains mediating signal transduction in the inhibitory glycine receptor chloride channel. EMBO J 16: 110-120.

Maddock RK, Jr., Bloomer HA (1967). Meprobamate overdosage. Evaluation of its severity and methods of treatment. JAMA 201: 999-1003.

Maguire J, Mody I (2008). GABA(A)R plasticity during pregnancy: relevance to postpartum depression. Neuron 59: 207-213.

Maguire J, Ferando I, Simonsen C, Mody I (2009). Excitability changes related to GABAA receptor plasticity during pregnancy. J Neurosci 29: 9592-9601.

Maguire JL, Stell BM, Rafizadeh M, Mody I (2005). Ovarian cycle-linked changes in GABA(A) receptors mediating tonic inhibition alter seizure susceptibility and anxiety. Nat Neurosci 8: 797-804.

Maldonado-Aviles JG, Curley AA, Hashimoto T, Morrow AL, Ramsey AJ, O'Donnell P, et al. (2009). Altered markers of tonic inhibition in the dorsolateral prefrontal cortex of subjects with schizophrenia. Am J Psychiatry 166: 450-459. 
Marshall FH, Jones KA, Kaupmann K, Bettler B (1999). GABAB receptors - the first 7TM heterodimers. Trends Pharmacol Sci 20: 396-399.

McKernan RM, Rosahl TW, Reynolds DS, Sur C, Wafford KA, Atack JR, et al. (2000). Sedative but not anxiolytic properties of benzodiazepines are mediated by the GABA(A) receptor alpha1 subtype. Nat Neurosci 3: 587-592.

McKinley DD, Lennon DJ, Carter DB (1995). Cloning, sequence analysis and expression of two forms of mRNA coding for the human beta 2 subunit of the GABAA receptor. Brain Res Mol Brain Res 28: 175-179.

Meldrum BS (2000). Glutamate as a neurotransmitter in the brain: review of physiology and pathology. J Nutr 130: 1007S-1015S.

Merali Z, Du L, Hrdina P, Palkovits M, Faludi G, Poulter MO, et al. (2004). Dysregulation in the suicide brain: mRNA expression of corticotropin-releasing hormone receptors and GABA(A) receptor subunits in frontal cortical brain region. J Neurosci 24: 1478-1485.

Meyer LM, Heeve WL, Bertscher RW (1957). Aplastic anemia after meprobamate (2-methyl2-N-propyl-1,3-propanediol dicarbamate) therapy. N Engl J Med 256: 1232-1233. 
Miyazawa A, Fujiyoshi Y, Unwin N (2003). Structure and gating mechanism of the acetylcholine receptor pore. Nature 423: 949-955.

Mody I, De Koninck Y, Otis TS, Soltesz I (1994). Bridging the cleft at GABA synapses in the brain. Trends Neurosci 17: 517-525.

Mohler H, Battersby MK, Richards JG (1980). Benzodiazepine receptor protein identified and visualized in brain tissue by a photoaffinity label. Proc Natl Acad Sci U S A 77: 1666-1670.

Mohr RC, Mead BT (1958). Meprobamate addiction. N Engl J Med 259: 865-868.

Moss SJ, Smart TG (2001). Constructing inhibitory synapses. Nat Rev Neurosci 2: 240-250.

Mtchedlishvili Z, Lepsveridze E, Xu H, Kharlamov EA, Lu B, Kelly KM (2010). Increase of GABAA receptor-mediated tonic inhibition in dentate granule cells after traumatic brain injury. Neurobiol Dis 38: 464-475.

Nayeem N, Green TP, Martin IL, Barnard EA (1994). Quaternary structure of the native GABAA receptor determined by electron microscopic image analysis. J Neurochem 62: 815818. 
Nusser Z, Cull-Candy S, Farrant M (1997). Differences in synaptic GABA(A) receptor number underlie variation in GABA mini amplitude. Neuron 19: 697-709.

Olsen RW, Sieghart W (2008). International Union of Pharmacology. LXX. Subtypes of gamma-aminobutyric acid(A) receptors: classification on the basis of subunit composition, pharmacology, and function. Update. Pharmacol Rev 60: 243-260.

Orser BA, Wang LY, Pennefather PS, MacDonald JF (1994). Propofol modulates activation and desensitization of GABAA receptors in cultured murine hippocampal neurons. $J$ Neurosci 14: 7747-7760.

Osvath P, Fekete S (2003). [Characteristics of the choice of psychotropic drugs in suicide attempts]. Orv Hetil 144: 121-124.

Paydar A, Lee B, Gangadharan G, Lee S, Hwang EM, Shin HS (2014). Extrasynaptic GABAA receptors in mediodorsal thalamic nucleus modulate fear extinction learning. Mol Brain 7: 39.

Pennington VM (1957). Use of Miltown (meprobamate) with psychotic patients. Am $J$ Psychiatry 114: 257-260.

Rho JM, Donevan SD, Rogawski MA (1997). Barbiturate-like actions of the propanediol dicarbamates felbamate and meprobamate. J Pharmacol Exp Ther 280: 1383-1391. 
Rivera C, Voipio J, Payne JA, Ruusuvuori E, Lahtinen H, Lamsa K, et al. (1999). The K+/Clco-transporter KCC2 renders GABA hyperpolarizing during neuronal maturation. Nature 397: 251-255.

Rudolph U, Mohler H (2004). Analysis of GABAA receptor function and dissection of the pharmacology of benzodiazepines and general anesthetics through mouse genetics. Annu Rev Pharmacol Toxicol 44: 475-498.

Rudolph U, Crestani F, Benke D, Brunig I, Benson JA, Fritschy JM, et al. (1999). Benzodiazepine actions mediated by specific gamma-aminobutyric acid(A) receptor subtypes. Nature 401: 796-800.

Sarkar J, Wakefield S, MacKenzie G, Moss SJ, Maguire J (2011). Neurosteroidogenesis is required for the physiological response to stress: role of neurosteroid-sensitive GABAA receptors. J Neurosci 31: 18198-18210.

Schoch P, Richards JG, Haring P, Takacs B, Stahli C, Staehelin T, et al. (1985). Co-localization of GABA receptors and benzodiazepine receptors in the brain shown by monoclonal antibodies. Nature 314: 168-171. 
Schofield PR, Darlison MG, Fujita N, Burt DR, Stephenson FA, Rodriguez H, et al. (1987). Sequence and functional expression of the GABA A receptor shows a ligand-gated receptor super-family. Nature 328: 221-227.

Shen H, Gong QH, Yuan M, Smith SS (2005). Short-term steroid treatment increases delta GABAA receptor subunit expression in rat CA1 hippocampus: pharmacological and behavioral effects. Neuropharmacology 49: 573-586.

Shimada S, Cutting G, Uhl GR (1992). gamma-Aminobutyric acid A or C receptor? gammaAminobutyric acid rho 1 receptor RNA induces bicuculline-, barbiturate-, and benzodiazepineinsensitive gamma-aminobutyric acid responses in Xenopus oocytes. Mol Pharmacol 41: 683687.

Sieghart W (1995). Structure and pharmacology of gamma-aminobutyric acidA receptor subtypes. Pharmacol Rev 47: 181-234.

Siegwart R, Jurd R, Rudolph U (2002). Molecular determinants for the action of general anesthetics at recombinant alpha(2)beta(3)gamma(2)gamma-aminobutyric acid(A) receptors. J Neurochem 80: 140-148.

Sigel E, Buhr A (1997). The benzodiazepine binding site of GABAA receptors. Trends Pharmacol Sci 18: 425-429. 
Smith SS, Ruderman Y, Frye C, Homanics G, Yuan M (2006). Steroid withdrawal in the mouse results in anxiogenic effects of 3alpha,5beta-THP: a possible model of premenstrual dysphoric disorder. Psychopharmacology (Berl) 186: 323-333.

Stroud GM (1957). Drug eruptions due to meprobamate. N Engl J Med 256: 354-355.

Taboulet P, Bismuth C (1994). [Shock caused by poisoning. Use of cardiotropic agents]. Presse Med 23: 1263-1268.

Tan KR, Brown M, Labouebe G, Yvon C, Creton C, Fritschy JM, et al. (2010). Neural bases for addictive properties of benzodiazepines. Nature 463: 769-774.

Tang X, Hernandez CC, Macdonald RL (2010). Modulation of spontaneous and GABAevoked tonic alpha4beta3delta and alpha4beta3gamma2L GABAA receptor currents by protein kinase A. J Neurophysiol 103: 1007-1019.

Thompson AJ, Lester HA, Lummis SC (2010). The structural basis of function in Cys-loop receptors. $Q$ Rev Biophys 43: 449-499.

Toyoshima C, Unwin N (1990). Three-dimensional structure of the acetylcholine receptor by cryoelectron microscopy and helical image reconstruction. J Cell Biol 111: 2623-2635. 
Tretter V, Ehya N, Fuchs K, Sieghart W (1997). Stoichiometry and assembly of a recombinant GABAA receptor subtype. J Neurosci 17: 2728-2737.

Underwood TW, Frye CB (1993). Drug-induced pancreatitis. Clin Pharm 12: 440-448.

Unwin N (1993). Neurotransmitter action: opening of ligand-gated ion channels. Cell 72 Suppl: $31-41$.

van Rijnsoever C, Tauber M, Choulli MK, Keist R, Rudolph U, Mohler H, et al. (2004). Requirement of alpha5-GABAA receptors for the development of tolerance to the sedative action of diazepam in mice. J Neurosci 24: 6785-6790.

Verpooten GA, De Broe ME (1982). Prediction of the efficacy of hemoperfusion and hemodialysis in severe poisoning. Arch Toxicol Suppl 5: 304-306.

Wallis RA, Panizzon KL, Fairchild MD, Wasterlain CG (1992). Protective effects of felbamate against hypoxia in the rat hippocampal slice. Stroke 23: 547-551.

Whissell PD, Eng D, Lecker I, Martin LJ, Wang DS, Orser BA (2013). Acutely increasing deltaGABA(A) receptor activity impairs memory and inhibits synaptic plasticity in the hippocampus. Front Neural Circuits 7: 146. 
Whiting P, McKernan RM, Iversen LL (1990). Another mechanism for creating diversity in gamma-aminobutyrate type A receptors: RNA splicing directs expression of two forms of gamma 2 phosphorylation site. Proc Natl Acad Sci U S A 87: 9966-9970.

Williams CA, Angelman H, Clayton-Smith J, Driscoll DJ, Hendrickson JE, Knoll JH, et al. (1995). Angelman syndrome: consensus for diagnostic criteria. Angelman Syndrome Foundation. Am J Med Genet 56: 237-238.

Wlodarczyk AI, Sylantyev S, Herd MB, Kersante F, Lambert JJ, Rusakov DA, et al. (2013). GABA-independent GABAA receptor openings maintain tonic currents. J Neurosci 33: 39053914.

Xu M, Akabas MH (1996). Identification of channel-lining residues in the M2 membranespanning segment of the GABA(A) receptor alpha1 subunit. J Gen Physiol 107: 195-205. 


\section{CHAPTER II}




\title{
ASSESSMENT OF DIRECT GATING AND ALLOSTERIC MODULATORY EFFECTS OF MEPROBAMATE \\ IN RECOMBINANT GABAA RECEPTORS
}

\author{
Manish Kumar ${ }^{1}$ and Glenn H. Dillon ${ }^{1,2}$
}

Department of Physiology and Pharmacology and Center for Neuroscience,

Robert C. Byrd Health Sciences Center, West Virginia University, Morgantown, WV ${ }^{1}$ and Center for Neuroscience Discovery, University of North Texas Health Science

Center,

Fort Worth, $\mathrm{TX}^{2}$

Corresponding author: Glenn H. Dillon, Ph.D.

Center for Neuroscience Discovery, Institute for Healthy

Aging

University of North Texas Health Science Center

Fort Worth, TX 76107

Phone: $\quad$ (817)-735- 2427

E-mail: $\quad$ glenn.dillon@unthsc.edu 


\begin{abstract}
Meprobamate is a schedule IV anxiolytic and the primary metabolite of the muscle relaxant carisoprodol. Meprobamate modulates $\mathrm{GABA}_{\mathrm{A}}(\gamma$-aminobutyric acid type $\mathrm{A})$ receptors, and has barbiturate-like activity. To gain insight into its actions, we have conducted a series of studies using recombinant $\mathrm{GABA}_{\mathrm{A}}$ receptors. In $\alpha \mathrm{x} \beta \mathrm{z} \gamma 2 \mathrm{GABA}_{\mathrm{A}}$ receptors (where $\mathrm{x}=1-6$ and $\mathrm{z}=1-3$ ), the ability to enhance GABA-mediated current was evident for all $\alpha$ subunit isoforms, with the largest effect observed in $\alpha 5$-expressing receptors. Direct gating was present with all $\alpha$ subunits, although attenuated in $\alpha 3$-expressing receptors. Allosteric and direct effects were comparable in $\alpha 1 \beta 1 \gamma 2$ and $\alpha 1 \beta 2 \gamma 2$ receptors, whereas allosteric effects were enhanced in $\alpha 1 \beta 2$ compared to $\alpha 1 \beta 2 \gamma 2$ receptors. In "extrasynaptic" $(\alpha 1 \beta 3 \delta$ and $\alpha 4 \beta 3 \delta)$ receptors, meprobamate enhanced $\mathrm{EC}_{20}$ and saturating GABA currents, and directly activated these receptors. The barbiturate antagonist bemegride attenuated direct effects of meprobamate. Whereas pentobarbital directly gated homomeric $\beta 3$ receptors, meprobamate did not, and instead blocked the spontaneously open current present in these receptors. In wild type homomeric $\rho 1$ receptors, pentobarbital and meprobamate were ineffective in direct gating; a mutation known to confer sensitivity to pentobarbital did not confer sensitivity to meprobamate. Our results provide insight into the actions of meprobamate and parent therapeutic agents such as carisoprodol. Whereas, in general, actions of meprobamate were comparable to those of carisoprodol, differential effects of meprobamate at some receptor subtypes suggest potential advantages of meprobamate may be exploited. A re-assessment of previously synthesized meprobamate-related carbamate molecules for myorelaxant and other therapeutic indications is warranted.
\end{abstract}

Key words: $\mathrm{GABA}_{\mathrm{A}}$ receptor; meprobamate; carisoprodol; muscle relaxant; drug abuse 


\section{Introduction}

Meprobamate, a propanediol carbamate, was the first drug to be used as an anxiolytic agent, and was also prescribed as an anticonvulsant and sedative/hypnotic (Hendley et al., 1954). By the late 1950s, meprobamate was the most widely prescribed drug in the United States and in many other countries. It retained this position until diazepam the benzodiazepine diazepam was introduced into clinical use in late 1960 (Berger, 1964; Greenblatt et al., 1974). Within two years of introduction of meprobamate, cases of its abuse and withdrawal after long term use were reported (Ewing et al., 1957), and it was relatively soon thereafter listed as a controlled substance.

While meprobamate itself is no longer widely used, drugs metabolized to meprobamate are widely available, and misuse of these drugs is associated with serious side effects. One such drug is the centrally acting skeletal muscle relaxant carisoprodol, which remains highly prescribed for low back pain (Toth et al., 2004; Sullivan, 2015). Use of carisoprodol is associated with abuse and dependence, and related dangers such as psychomotor impairment (Elder, 1991; Rust et al., 1993; Zacny et al., 2011, 2012). Dependence and severe withdrawal may lead to seizures and death (Adams et al., 1975; Elder, 1991; Littrell et al., 1993; Rust et al., 1993; Reeves et al., 2003; Zacny et al., 2011; Zacny et al., 2012). Although carisoprodol has its own independent effects (Gonzalez et al., 2009b), many of its therapeutic and abuse-dependent effects are likely due to its metabolite meprobamate, which differs from carisoprodol by the absence of an isopropyl group (Fig. 1). Indeed, the half-life of meprobamate far exceeds that of carisoprodol ( $\mathrm{t} 1 / 2$ for carisoprodol of $1-2$ hours (Olsen et al., 1994) and t 1 1/2 for meprobamate between 6.4 hours and 16.6 hours (Hollister et al., 1964; Maddock et al., 1967).

Meprobamate has been shown to have barbiturate-like activity at neuronal $\mathrm{GABA}_{\mathrm{A}}$ receptors (Rho et al., 1997), the predominant inhibitory neurotransmitter receptor in the central nervous system and the target of many therapeutics. Carisoprodol has similarly been suggested to have barbiturate-like actions (Gonzalez et al., 2009a). A detailed understanding of meprobamate's interaction with $\mathrm{GABA}_{\mathrm{A}}$ receptors is lacking, however. For instance, the extent to which its 
interaction with $\mathrm{GABA}_{\mathrm{A}}$ receptors may be subunit-dependent is unknown. As the extensive array of $\mathrm{GABA}_{\mathrm{A}}$ receptor configurations that exist throughout the CNS contribute to specific physiological and pharmacological responses of GABA and modulatory agents (Olsen et al., 2008), an understanding of meprobamate's subunit-dependent actions could prove enlightening regarding therapeutic and adverse effects of both it and parent therapeutics that are metabolized to meprobamate, such as carisoprodol. We have thus assessed the potential subunit-dependent interaction of meprobamate at these receptors and have further explored potential commonality and differences of action with barbiturates. 


\section{Materials and Methods}

\subsection{Cell Culture and Transfection}

Human embryonic kidney 293 (HEK293) cells, stably or transiently expressing varying $\mathrm{GABA}_{\mathrm{A}}$ receptor subunits, were used in the present study. For transient expression, cells were transfected with human GABAA $\alpha 1-\alpha 6$; human $\beta 1-2$; and human $\gamma 2$ s (short isoform) cDNA in a 1:1:5 ratio $(2 \mu \mathrm{g}$ total $\mathrm{cDNA})$ using PolyJet ${ }^{\mathrm{TM}}$ in vitro transfection reagent (SignaGen Laboratories, Jamesville, MD). The $\gamma 2 \mathrm{~s}$ subunit will be referred to as $\gamma 2$ from here forward. For studies assessing meprobamate effects in a model of extrasynaptic receptors (rat $\alpha 1 \beta 3 \delta$ and $\alpha 4 \beta 3 \delta$ subunits), a total of $3 \mu \mathrm{g}$ of cDNA in a transfection ratio of 2:1:0.25 for $\alpha: \beta: \delta$ plasmids was used (Wagoner et al., 2010). For studies on wild type $\beta 3$ homomeric receptors, wild type $\rho 1$ subunits, and barbituratesensitive $\rho 1$ (W328M) subunits (generated previously in our lab, Gonzalez et al, 2009b), $2 \mu \mathrm{g}$ of cDNA was transfected. The rat $\mathrm{GABA}_{\mathrm{A}} \alpha 4$ subunit cDNA was purchased from Genescript (Piscataway, New Jersey). Human GABAA $\alpha 1$ subunit cDNA was generously provided by Neil Harrison (Columbia University Medical Center, New York). The wild-type human GABA $\rho 1$ subunit was generously provided by David Weiss (University of Texas Health Science Center at San Antonio). HEK293 cells stably expressing human $\alpha 2 \beta 2 \gamma 2$ receptors were also used. A complete description of the preparation and maintenance of these stable cell lines has been published previously (Hawkinson et al., 1996). Cells were plated on glass coverslips coated with poly-L-lysine in $35-\mathrm{mm}$ culture dishes, and maintained at $37^{\circ} \mathrm{C}$ in a humidified incubator with an atmosphere of 5\% $\mathrm{CO}_{2}$. In all cases, cells were used for recording 24-72 hr after transfection.

\subsection{Electrophysiology}

Whole-cell patch clamp electrophysiology was used to assess GABA-, meprobamate-, or pentobarbital-activated $\mathrm{Cl}^{-}$currents. All electrophysiology experiments were conducted at room 
temperature $\left(22-25{ }^{\circ} \mathrm{C}\right)$ with the membrane potential clamped at $-60 \mathrm{mV}$. Patch pipettes of borosilicate glass (1B150F; World Precision Instruments, Inc., Sarasota, FL) were pulled (Flaming/Brown, P-87/PC; Sutter Instrument Company, Novato, CA) to a tip resistance of 4-6M $\Omega$. Patch pipettes were filled with a solution consisting of $140 \mathrm{mM} \mathrm{CsCl}, 10 \mathrm{mM}$ EGTA-Na+, $10 \mathrm{mM}$ HEPES-Na+, and $4 \mathrm{mM} \mathrm{Mg}{ }^{2+}-\mathrm{ATP}, \mathrm{pH}$ 7.2. Coverslips containing cultured cells were placed in the recording chamber on the stage of an inverted light microscope and superfused continuously with an external solution consisting of $125 \mathrm{mM} \mathrm{NaCl}, 20 \mathrm{mM}$ HEPES, $3 \mathrm{mM} \mathrm{CaCl}$, $5.5 \mathrm{mM} \mathrm{KCl}, 0.8$ $\mathrm{mM} \mathrm{MgCl}$, and $10 \mathrm{mM}$ glucose, $\mathrm{pH}$ 7.3. Agonist-induced $\mathrm{Cl}^{-}$currents were obtained with an Axopatch 200B amplifier (Molecular Devices, Sunnyvale, CA) equipped with a CV-203BU headstage. Currents were low-pass filtered at $5 \mathrm{kHz}$, monitored simultaneously on an oscilloscope and a chart recorder (Gould TA240; Gould Instrument Systems Inc., Cleveland, OH), and stored on a computer using an on-line data acquisition system (pCLAMP 6.0; Axon Instruments) for subsequent off-line analysis.

\subsection{Chemicals and solutions}

Meprobamate, carisoprodol, pentobarbital, diazepam, THIP (4,5,6,7tetrahydroisoxazolo(5,4-c)pyridin-3-ol), salts and buffers were purchased from Sigma Aldrich (St. Louis, MO). GABA was obtained from Acros Organics (New Jersey, US). Bemegride was obtained from Pfaltz \& Bauer, Inc. (Waterbury, CT). Stock solutions of meprobamate, pentobarbital and carisoprodol were made using dimethylsulfoxide (DMSO). Drugs were diluted in normal saline, so that the final DMSO concentration ( $\mathrm{vol} / \mathrm{vol}$ ) of the test solutions was $\leq 0.3 \%$. GABA, diazepam and bemegride stock solutions were prepared using de-ionized $\mathrm{H}_{2} \mathrm{O}$. All stock solutions were stored at $-20{ }^{\circ} \mathrm{C}$. On experimental days, drug-containing solutions were prepared from stock by serial dilution into external solution. 


\subsection{Experimental Protocol}

GABA (with or without modulatory ligand), meprobamate, carisoprodol or pentobarbital were prepared in external solution on the day of use and applied via a 16-barrel rapid perfusion system in which all barrels ( $200 \mu \mathrm{m}$ outer diameter quartz tubes; ALA Scientific, Folsom, CA) emptied via a common tip positioned adjacent to the cell under study. Flow through each barrel was pressure fed and regulated by solenoid or pinch valves operated by a programmable microprocessor-based controller. Only one valve was open at a time, and the buffer solution was applied continuously between drug applications via gravity or positive pressure. As per the manufacturer specifications, solution flow rate as configured in the present studies is approximately $3 \mu \mathrm{l} / \mathrm{second}$, and exchange rate is approximately $5 \mathrm{msec}$. For some experiments, ligands were applied via gravity flow using a Y-tube placed adjacent to the cell.

The modulatory effects of meprobamate on GABA-gated currents were assessed using an $\mathrm{EC}_{20}$ gating concentration of $\mathrm{GABA}$ as the control. This gating concentration was selected to ensure there was a sufficient range to observe the full allosteric potential of meprobamate. To ensure the gating concentration was approximately an $\mathrm{EC}_{20}$, control responses were compared to the maximal GABA-gated current for each individual cell. On a cell by cell basis, control GABA currents were deemed acceptable for assessment of allosteric modulatory effects of meprobamate if they were within a 15-25\% range of maximal current for that particular cell. Control responses were established by observing two consecutive agonist-activated currents that varied in amplitude by no more than $\pm 10 \%$. In our analyses of the modulatory effects of meprobamate, peak current amplitude was defined as the maximum current elicited by meprobamate. For studies investigating meprobamate-mediated currents, meprobamate was dissolved in external solution and applied in the manner described above. In all studies assessing direct gating effects of meprobamate, the magnitude of the response was expressed relative to the maximal effect of GABA (designated $100 \%$ ). In studies on $\beta 3$ homomeric receptors, the magnitude of meprobamate-mediated block of spontaneously open channels was measured relative to the maximal blocking effect of picrotoxin 
(designated 100\%). For $\alpha \beta \gamma$ configurations, GABA-gated control currents were recorded in the presence of diazepam to confirm incorporation of the $\gamma 2$ subunit. Presence of the $\delta$ subunit in $\alpha 1 \beta 3 \delta$

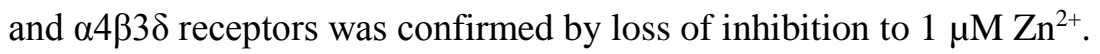

\subsection{Data Analysis}

To ensure equipotent concentrations were used for gating, GABA concentration-response data were collected for all synaptic and extrasynaptic $\mathrm{GABA}_{\mathrm{A}}$ receptors tested, (Table 1). From these data, $\mathrm{EC}_{20}$ and saturating $\mathrm{GABA}$ concentrations were calculated for each configuration and used in subsequent investigations of the allosteric and direct effects of meprobamate, respectively. For studies assessing allosteric actions of meprobamate, a correction was applied to subtract underlying direct gating effects, which were present at higher meprobamate concentrations. All data are presented as mean \pm S.E.M. For experiments in which three or more datasets were statistically analyzed, one-way analysis of variance was conducted, followed by a Tukey-Kramer post hoc test as indicated. For those experiments in which two datasets were analyzed, Student's t-tests (paired or unpaired) were conducted. In all cases, statistical significance was designated at a $\mathrm{p}$ value of 0.05 or less. 


\section{Results}

\section{$3.1 \alpha$ subunit isoform influence on direct and allosteric actions of meprobamate}

Direct effects of meprobamate were assessed in $\alpha x \beta 2 \gamma 2 \mathrm{GABA}_{\mathrm{A}}$ receptors, where $\mathrm{x}=\alpha$ subunit 1-6. We initiated direct gating studies using concentrations of meprobamate as low as 100 $\mu \mathrm{M}$; as direct gating effects were not generally observed below $1 \mathrm{mM}$, we report here direct gating effects of 1, 3 and $10 \mathrm{mM}$ meprobamate. Meprobamate directly gated each of the configurations tested at high concentrations, evoking inward currents in the absence of GABA (Fig. 2). The relatively low apparent affinity of meprobamate combined with limits on its solubility precluded definitive calculation of maximal meprobamate-gated current. At $10 \mathrm{mM}$, meprobamate-gated current was of similar magnitude in $\alpha 1-, \alpha 2-, \alpha 4-, \alpha 5-$ and $\alpha 632 \gamma 2 \mathrm{~s} \mathrm{GABA}_{\mathrm{A}}$ receptors $(20-36 \%$ of maximal GABA current), and significantly less (7\%) in $\alpha 3$-expressing receptors (Fig. 2).

We also assessed $\alpha$ subunit isoform effects on allosteric modulatory actions of meprobamate. Meprobamate positively modulated the effects of $\mathrm{GABA} \mathrm{EC}_{20}$ concentration in all configurations tested (Fig. 3). $3 \mathrm{mM}$ meprobamate on average roughly doubled the amplitude of the $\mathrm{GABA} \mathrm{EC}_{20}$ current for most $\alpha$ subunit isoforms. We observed a somewhat enhanced effect in receptors expressing the $\alpha 5$ subunit, as $3 \mathrm{mM}$ meprobamate elicited a potentiating effect of more than 3-fold (Fig. 3).

\section{$3.2 \beta$ subunit isoform influence on direct and allosteric actions of meprobamate}

To assess whether the $\beta$ subunit isoform affected the actions of meprobamate, we assessed both direct and allosteric effects of it in $\alpha 1 \beta 2 \gamma 2$ and $\alpha 1 \beta 1 \gamma 2$ receptors. We observed no significant difference in the magnitude of current elicited by meprobamate alone in these receptors, as $10 \mathrm{mM}$ meprobamate elicited currents roughly $1 / 3$ the amplitude of peak GABA current in both $\alpha 1 \beta 2 \gamma 2$ and $\alpha 1 \beta 1 \gamma 2$ receptors (Fig. $2 \mathrm{C}$ ). 
With regard to $\beta$ subunit effects on allosteric actions of meprobamate, we found receptors expressing either $\beta 1$ or $\beta 2$ subunits (in combination with $\alpha 1$ and $\gamma 2$ ) showed similar allosteric modulation by meprobamate. In both receptors, $3 \mathrm{mM}$ meprobamate effectively doubled the amplitude of GABA-gated current (Fig. 3C).

\section{3 r subunit isoform influence on direct and allosteric actions of meprobamate}

Presence of a $\gamma$ subunit is critical for the allosteric actions of benzodiazepines (Pritchett et al., 1989), but not for direct or allosteric effects of other ligands such as barbiturates (Horne et al., 1993) or neurosteroids (Hosie et al., 2006). To assess the extent to which the $\gamma$ subunit impacts actions of meprobamate, we tested effects of it in receptors lacking the $\gamma 2$ subunit. In comparison to $\alpha 1 \beta 2 \gamma 2$ receptor, direct gating in $\alpha 1 \beta 2$ receptor was generally comparable. There was a statistically smaller direct gating response at $1 \mathrm{mM}$ meprobamate in $\alpha 1 \beta 2$ receptor compared to $\alpha 1 \beta 2 \gamma 2$ receptor, but this difference was modest and not present at other concentrations tested (Fig. 2D).

The $\gamma 2$ subunit had a more prominent effect on allosteric modulation by meprobamate. Its presence significantly attenuated the ability of meprobamate to allosterically an $\mathrm{EC}_{20}$ concentration of GABA at all concentrations of MEP above $100 \mu \mathrm{M}$. At 1 and $3 \mathrm{mM}$ MEP, the magnitude of enhancement in $\alpha 1 \beta 2$ receptors was more than twice that observed in $\alpha 1 \beta 2 \gamma 2$ receptors (Fig 3D).

\subsection{Effects of meprobamate on $\delta$-subunit containing "extrasynaptic" receptors}

GABA and ligands that regulate its receptors may act at synaptic or extrasynaptic sites. To assess the influence of meprobamate extrasynaptically, we studied its effect in recombinant $\alpha 4 \beta 3 \delta$ and $\alpha 1 \beta 3 \delta$ receptors, models of extrasynaptic $\mathrm{GABA}_{\mathrm{A}}$ receptors. As reported by others (Brown et al., 2002), sensitivity of $\alpha 4 \beta 3 \delta$ receptors to GABA was high, with an $\mathrm{EC}_{50}$ of $0.04 \pm 0.02 \mu \mathrm{M}$. As

shown in Figure 4, meprobamate directly gated $\alpha 4 \beta 3 \delta$ receptors with an efficacy comparable to 
that of GABA itself. This direct gating effect was concentration-dependent, and saturated at $3 \mathrm{mM}$ meprobamate. We found very similar effects for the ability of meprobamate to directly gate $\alpha 1 \beta 3 \delta$ receptors. Sensitivity to the direct gating effects in extrasynaptic receptors was comparable to that observed in synaptic receptors. Current gated by meprobamate rapidly decayed following activation, and we noted a prominent rebound effect following termination of ligand application (Fig 4A, arrow). GABA is not a full agonist in $\delta$-expressing receptors (Brown et al., 2002); we observed the same effect, as the agonist THIP elicited a current $151 \pm 12 \%$ of that elicited by saturating GABA.

We also assessed the extent to which meprobamate might allosterically potentiate extrasynaptic $\mathrm{GABA}_{\mathrm{A}}$ receptors. As illustrated in Fig. 5, meprobamate enhanced GABA-gated $\left(\mathrm{EC}_{20}\right)$ current, with a threshold effect at $100 \mu \mathrm{M}$, and a maximal effect observed at $1 \mathrm{mM}$. The sensitivity and magnitude of the potentiating effect is comparable to that observed in synaptic receptors.

Pentobarbital and carisoprodol, the parent molecule to meprobamate, have been reported to enhance maximal GABA-gated current in $\delta$-subunit containing receptor (Feng et al., 2004; Kumar et al., 2015). We thus assessed for this capability with meprobamate. Co-application of 1 $\mathrm{mM}$ meprobamate with $1 \mathrm{mM} \mathrm{GABA}\left(\mathrm{EC}_{95+}\right)$ to $\alpha 4 \beta 3 \delta$ receptors resulted in a current $183 \pm 17 \%$ of that seen with maximal GABA alone. As anticipated, $100 \mu \mathrm{M}$ pentobarbital, which was used as a positive control, showed enhancement of maximal GABA-gated current (to $223 \pm 38 \%$ of maximal GABA, Fig. 6B). No enhancement was observed in $\alpha 1 \beta 3 \gamma$ or $\alpha 1 \beta 3$ subunit containing receptors with meprobamate or pentobarbital (Fig. 6B).

\subsection{Further assessment of the barbiturate-like effects of meprobamate}

Based on a mechanistic assessment of its effects in $\mathrm{GABA}_{\mathrm{A}}$ receptors recorded from cultured rat hippocampal neurons, others have concluded meprobamate has "barbiturate-like" 
activity (Rho et al., 1997). Our results are broadly consistent with that suggestion. We thus conducted additional studies to test further commonality of action between meprobamate and pentobarbital.

Bemegride is known to antagonize pentobarbital stimulus effect in animal models (Schechter, 1984) and phenobarbital direct gating effects in mouse spinal neurons (Mistry et al., 1990). We thus assessed the influence of bemegride on the direct gating effects of meprobamate. As shown in Figure 7, meprobamate-mediated direct gating current was significantly and reversibly attenuated by bemegride. The ability of bemegride to antagonize meprobamate-activate current was greater when tested against a lower concentration of meprobamate, demonstrating a concentration-dependent effect.

$\rho 1$ homomeric GABA receptors are anion-selective cys loop ligand-gated channels, with a pharmacology distinct from that of heteromeric $\mathrm{GABA}_{\mathrm{A}}$ receptors (Amin et al., 1994). They are found in very high concentration in retina and other visual areas (Enz et al., 1995; Boue-Grabot et al., 1998). Barbiturates cannot directly activate wild type $\rho 1$ homomeric GABA receptors, but can when tryptophan at position 328 is mutated to methionine (W328M) (Amin, 1999). We assessed whether meprobamate can gate wild type or $\mathrm{W} 328 \mathrm{M} \rho 1$ homomeric GABA receptors. In wild type homomeric $\rho 1$ receptors, both pentobarbital and meprobamate were ineffective in direct gating (Fig. 7A, 7B). As originally reported (Amin, 1999), we observed that the W328M mutation in the 1 subunit conferred sensitivity to direct gating effects of pentobarbital. In contrast, the W328M mutation did not confer on meprobamate the ability to directly gate the channel (Fig. 7A, 7B).

Homomeric $\beta 3$ receptors do not appear to form natively, but they can form a functional receptor in vitro, and thus are a useful tool for studying drug action (Davies et al., 1997; Chen et al., 2012). Homomeric $\beta 3$ receptors are spontaneously open, and they can be directly activated by barbiturates (Davies et al., 1997). We evaluated whether meprobamate had direct gating effects in these receptors. Meprobamate, in contrast to pentobarbital, could not directly gate homomeric $\beta 3$ 
receptors. Instead, meprobamate, blocked the spontaneously open current present in homomeric $\beta 3$ receptors (Fig. 7A, 7B). This effect was concentration-dependent, and approached the efficacy of the GABA receptor antagonist picrotoxin in blocking the spontaneously open channel (Fig. 7B). 


\section{Discussion}

This is the first study to assess subunit-dependent effects of meprobamate at its major target, $\mathrm{GABA}_{\mathrm{A}}$ receptors. Drugs metabolized to meprobamate, such as carisoprodol, have remained widely utilized. Carisoprodol was actually synthesized as an alternative to meprobamate, and early studies suggested it had a profile that was preferable to meprobamate (Berger et al., 1960). Early metabolism studies in dogs indicated the primary metabolite of carisoprodol was hydroxylcarisoprodol (Douglas et al., 1962). Toxicology studies some years later demonstrated that in humans, carisoprodol was in fact metabolized primarily to meprobamate, which has a half-life that is several-fold longer than that of carisoprodol (Bramness et al., 2004; Olsen et al., 1994). Whereas the recent scheduling of carisoprodol will likely result in a reduction in its use (Bramness et al., 2012), it remains a key therapeutic for treatment of acute low back pain (Witenko et al., 2014). Even with its recent scheduling, a quick internet search reveals a number of pharmacies noting the ready availability of carisoprodol without a prescription. Thus the potential for continuing abuse of carisoprodol remains. Considering a significant proportion of its effect are likely attributable to its metabolite meprobamate, the focus of the present study was thus to gain greater insight into meprobamate modulation of its major therapeutic target, the $\mathrm{GABA}_{\mathrm{A}}$ receptor.

Our assessment of meprobamate's ability to directly gate and allosterically modulate the $\mathrm{GABA}_{\mathrm{A}}$ receptor is comparable to that reported in neurons (Rho et al., 1997), in that both effects are of relatively low potency. Rho et al. (1997) further categorized its actions as "barbiturate-like", and carisoprodol also displays barbiturate-like effects both in vivo and in vitro (Gonzalez et al., 2009b). We conducted a number of experiments to better understand the extent to which effects of meprobamate mimic those of the barbiturate pentobarbital. The results demonstrate some commonality of effect between the two ligands, but in general do not support a common site of action for meprobamate and barbiturates. The barbiturate antagonist bemegride reversibly and significantly inhibited meprobamate-mediated direct gating current in a concentration-dependent manner, consistent with a competitive nature of inhibition. However, in homomeric $\rho 1$ receptors, 
a mutation (W328M) that conferred sensitivity to pentobarbital (Amin, 1999) did not confer sensitivity to meprobamate. In addition, whereas pentobarbital could directly gate homomeric $\beta 3$ receptors, this effect was not observed with meprobamate. Thus, whereas a number of in vivo and in vitro actions of meprobamate are in fact similar to those observed with pentobarbital, the comparison cannot be extended to indicate a common binding domain for these ligands. In this regard, meprobamate is comparable to carisoprodol (Gonzalez et al., 2009b). Recent photoaffinity labeling studies have provided considerable evidence that barbiturates bind to inter-subunit interfaces in $\mathrm{GABA}_{\mathrm{A}}$ (Chiara et al., 2013) and nicotinic (Hamouda et al., 2014) receptors. With regard to $\mathrm{GABA}_{\mathrm{A}}$ receptors, a photoreactive barbiturate binds to a number of residues at both the $\alpha-\beta$ and $\gamma-\beta$ interfaces in the transmembrane domain (Chiara et al., 2013). Our current results suggest it unlikely that meprobamate would interact with those residues.

It has become increasingly clear in recent years that many therapeutic and adverse actions of GABAergic drugs associate predominantly with particular subunits of the $\mathrm{GABA}_{\mathrm{A}}$ receptor (Low et al., 2000; Crestani et al., 2001; Crestani et al., 2002; van Rijnsoever et al., 2004; Licata et al., 2008; Tan et al., 2010; Rudolph et al., 2014). Of particular relevance to the current study is the fact that $\alpha 2$ - and $\alpha 3$ expressing receptors are involved in both anxiolytic (Low et al., 2000; Crestani et al., 2001; Licata et al., 2008) and muscle-relaxing (Crestani et al., 2001; Griebel et al., 2003) effects of GABAergic ligands, while abuse potential associates with the $\alpha 1$ subunit (Licata et al., 2008; Tan et al., 2010). Our recent report (Kumar et al., 2015) shed some light on the subunitdependent effects of carisoprodol itself and how they may relate to its therapeutic and advserse effects. To fully understand actions of carisoprodol, it is necessary to also understand potential subunit-dependent effects of the primary and comparatively long-lived metabolite, meprobamate. At the maximal concentration assessed, meprobamate-gated current was of similar magnitude in $\alpha 1-, \alpha 2-, \alpha 4-, \alpha 5-$ and $\alpha 6 \beta 2 \gamma 2 \mathrm{~s} \mathrm{GABA}{ }_{A} R s$, and significantly less in $\alpha 3$-expressing receptors. The parent drug carisoprodol has a similar profile, with roughly three-fold higher potency (Kumar et 
al., 2015). With regard to allosteric modulation, carisoprodol displayed considerably greater efficacy in $\alpha 1$-expressing receptors (Kumar et al., 2015), whereas meprobamate displayed generally similar effects regardless of $\alpha$ subunit, with some enhanced efficacy in $\alpha 5$-expressing receptors.

The lack of effect of $\beta$ subunit isoform on direct gating or allosteric effects of meprobamate contrasts with carisoprodol, in which direct gating was most efficacious in $\beta 1$-expressing receptors, and allosteric modulation was greatest in $\beta 2$-expressing receptors (Kumar et al., 2015). In addition, whereas the $\gamma$ subunit did not have an effect on direct gating or allosteric modulation of carisoprodol (Kumar et al., 2015), its presence quite markedly attenuated the modulatory capacity of meprobamate. This effect may not be therapeutically significant as few native receptors express only $\alpha$ and $\beta$ subunits, but it may prove useful in identifying critical domains for effects of meprobamate.

Ligands that influence the actions of GABA may also act at extrasynaptic $\mathrm{GABA}_{\mathrm{A}}$ receptors, which include $\alpha 4 \beta 3 \delta$ and $\alpha 1 \beta 3 \delta$ subtypes; these receptors have been implicated in diseases such as schizophrenia, depression and epilepsy (Brickley et al., 2012). Meprobamate directly gated these receptors with an efficacy comparable to that of GABA, which is a partial agonist in these receptors (Bianchi et al., 2003). We also observed that GABA's efficacy was about $2 / 3$ that of the full agonist THIP in $\delta$ subunit-expressing receptors. Barbiturates (Feng et al., 2004), neurosteroids (Wohlfarth et al., 2002) and the parent drug carisoprodol (Kumar et al., 2015) all have the ability to enhance the actions of a saturating concentration of GABA in extrasynaptic receptors. We observed a similar effect of meprobamate in the present investigation. Whereas a portion of the peak GABA current enhancement could be attributable to some direct action of meprobamate, the majority of the enhancement may relate to shifting of GABA from a low efficacy to high efficacy ligand (Bianchi et al., 2003).

In considering where on the receptor meprobamate acts, key questions include: 1) is the site(s) where meprobamate acts the same as that for carisoprodol?; and 2) does meprobamate acts 
at distinct sites for gating and allosteric effects? When initiating these studies, we hypothesized that the two ligands act at the same site for both effects. As noted, experimental evidence has shown that both carisoprodol and meprobamate allosterically modulate, directly gate and inhibit the $\mathrm{GABA}_{\mathrm{A}}$ receptor. Both ligands also display similar actions at $\delta$-expressing receptors. Specifically with regard to question 1 above, we consider here both direct and allosteric effects. Results for direct gating studies demonstrate the subunit-dependent profile for the two ligands are quite similar, and the main difference between the two ligands is potency. These data are consistent with a single overlapping site of action. The isopropyl group of carisoprodol may enhance hydrophobic interactions that result in its enhanced potency. In considering allosteric modulatory effects of the two ligands, the subunit-dependent profile showed significantly more variability than that observed for direct gating effects. The influence of $\alpha, \beta$ and $\gamma$ subunits was different for meprobamate compared to carisoprodol. Although a definitive conclusion is not warranted, the data are consistent with only modestly overlapping or possibly distinct sites for allosteric effects of meprobamate, compared to carisoprodol. Further studies are required to more definitively address this issue.

In considering whether the direct and allosteric effects of meprobamate are mediated via one or two sites, the possibility of two sites is likely. With regard to carisoprodol, separate sites for direct gating and allosteric modulatory effects have been proposed (Kumar and Dillon, 2015). As with carisoprodol, the subunit-dependent profiles for direct and allosteric effects of meprobamate are distinct. Additional evidence suggestive of distinct sites comes from recent mutagenesis studies. We have reported in abstract form (Kumar et al., 2013) the fact that amino acid mutations in transmembrane domain IV of the $\alpha$ subunit impact direct gating of carisoprodol, but have no significant effect on its allosteric actions. Unpublished results of effects of these mutations on the actions of meprobamate suggest a similar effect. Whether the amino acid residues in question form part of the binding site for these ligands or are critical for transduction is not 
known. Nevertheless, the fact that the mutations had effects only on direct gating is consistent with the conclusion that distinct sites exist for direct and allosteric modulatory effects for both meprobamate and carisoprodol.

Our results provide additional insight regarding the therapeutic and abuse-facilitating effects of carisoprodol. Both carisoprodol and meprobamate display direct gating and allosteric modulatory effects on $\mathrm{GABA}_{\mathrm{A}}$ receptors across the spectrum of $\alpha$-expressing receptors, which supports physical dependence and abuse potential (Licata et al., 2008). Both ligands effectively modulate $\alpha 2$-, $\alpha 3$ - and $\alpha 5$-expressing receptors, which provides an effective muscle relaxant profile (Crestani et al., 2001; Griebel et al., 2003. Drawing further from an understanding of benzodiazepines, the considerably higher efficacy (and potency) of carisoprodol for allosteric enhancement of $\alpha 1$-expressing receptors would seem to be a key contributor for its abuse and addictive potential (Licata and Rowlett, 2008; Tan et al., 2010). In addition, in a study of impaired and unimpaired drivers, blood concentration of carisoprodol, but not meprobamate, correlated with driver impairment (Bramness et al., 2004). The authors concluded that carisoprodol itself has impairing effects. As sedative effects are strongly associated with activity at $\alpha 1$-expressing receptors, our finding that meprobamate has considerably reduced effects at these receptors, compared to carisoprodol, provides a molecular basis in support of the conclusion of Bramness et al. (2004). Meprobamate itself has important limitations as a therapeutic; hence its classification as a scheduled drug decades ago. However, as meprobamate strongly modulates $\alpha 5$-expressing receptors (consistent with muscle relaxant effects), and has comparatively inefficient ability to modulate $\alpha 1$-expressing receptors (associated with dependence and abuse potential), a reevaluation of meprobamate for possible modification is warranted.

During the time period both meprobamate and carisoprodol were being widely prescribed, an extensive series of derivatives of them was generated (Ludwig et al., 1969). Many of these displayed enhanced potency for muscle relaxation (as measured via paralyzing effects that leads to 
loss of righting reflex) compared to both carisoprodol and meprobamate, as well as an enhanced safety margin. It appears none of these molecules made it to market. Whether they failed for safety or other reasons, or whether the decision to abandon this series of compounds was made in light of the subsequent scheduling of meprobamate is not known. Considering the availability of improved assays and our current understanding of molecular pharmacology associated with therapeutic effects, it might prove worthwhile to re-assess a number of these meprobamate-related carbamate molecules for myorelaxant and other indications. 


\section{Acknowledgements}

This work was supported by the National Institutes of Health National Institute of Drug Abuse

[Grant R01 DA022370 to GHD] and by National Institutes of General Medical Sciences Grant U54GM104942. We appreciate the technical assistance of Mr. John Freund and Ms. Cathy BellHorner. 


\section{References}

Adams, H. R., Kerzee, T., Morehead, C. D., 1975. Carisoprodol-related death in a child. J. Forensic Sci. 20, 200-202.

Amin, J., 1999. A single hydrophobic residue confers barbiturate sensitivity to gammaaminobutyric acid type C receptor. Mol. Pharmacol. 55, 411-423.

Amin, J., Weiss, D. S., 1994. Homomeric rho 1 GABA channels: activation properties and domains. Recep. Chan. 2, 227-236.

Berger, F. M., 1964. Symposium on Anxiety and a Decade of Tranquilizer Therapy. The Tranquilizer Decade. J. Neuropsychiatr. 5, 403-410.

Berger, F. M., Kletzkin, M., Ludwig, B. J., Margolin, S., 1960. The history, chemistry, and pharmacology of carisoprodol. Ann. N. Y. Acad. Sci. 86, 90-107.

Bianchi, M. T., Macdonald, R. L., 2003. Neurosteroids shift partial agonist activation of GABA(A) receptor channels from low- to high-efficacy gating patterns. J. Neurosci. 23, 10934-10943.

Boue-Grabot, E., Roudbaraki, M., Bascles, L., Tramu, G., Bloch, B., Garret, M., 1998. Expression of GABA receptor rho subunits in rat brain. J. Neurochem. 70, 899-907.

Bramness, J. G., Furu, K., Skurtveit, S., Engeland, A., 2012. Effect of the market withdrawal of carisoprodol on use of other prescribed drugs with abuse potential. Clin. Pharmacol. Ther. $91,438-441$.

Bramness, J. G., Skurtveit, S., Morland, J., 2004. Impairment due to intake of carisoprodol. Drug Alcohol Depend. 74, 311-318.

Brickley, S. G., Mody, I., 2012. Extrasynaptic GABA(A) receptors: their function in the CNS and implications for disease. Neuron 73, 23-34.

Brown, N., Kerby, J., Bonnert, T.P., Whiting, P.H., Wafford, K.A., 2002. Pharmacological characterization of a novel cell line expressing human alpha(4)beta(3)delta GABA(A) receptors. Br. J. Pharmacol. 136, 965-974. 
Chen, Z. W., Manion, B., Townsend, R. R., Reichert, D. E., Covey, D. F., Steinbach, J. H., Sieghart, W., Fuchs, K., Evers, A. S., 2012. Neurosteroid analog photolabeling of a site in the third transmembrane domain of the beta3 subunit of the GABA(A) receptor. Mol. Pharmacol. $82,408-419$.

Chiara, D. C., Jayakar, S. S., Zhou, X., Zhang, X., Savechenkov, P. Y., Bruzik, K. S., Miller, K. W., Cohen, J. B., 2013. Specificity of intersubunit general anesthetic-binding sites in the transmembrane domain of the human alpha1beta3gamma2 gamma-aminobutyric acid type A (GABAA) receptor. J. Biol. Chem. 288, 19343-19357.

Crestani, F., Keist, R., Fritschy, J. M., Benke, D., Vogt, K., Prut, L., Bluthmann, H., Mohler, H., Rudolph, U., 2002. Trace fear conditioning involves hippocampal alpha5 GABA(A) receptors. Proc. Natl. Acad. Sci. U. S. A. 99, 8980-8985.

Crestani, F., Low, K., Keist, R., Mandelli, M., Mohler, H., Rudolph, U., 2001. Molecular targets for the myorelaxant action of diazepam. Mol. Pharmacol. 59, 442-445.

Davies, P. A., Kirkness, E. F., Hales, T. G., 1997. Modulation by general anaesthetics of rat GABAA receptors comprised of alpha 1 beta 3 and beta 3 subunits expressed in human embryonic kidney 293 cells. Br. J. Pharmacol. 120, 899-909.

Douglas, J. F., Ludwig, B. J., Schlosser, A., 1962. The metabolic fate of carisoprodol in dog. J. Pharmacol. Exp. Ther. 138, 21-27.

Elder, N. C., 1991. Abuse of skeletal muscle relaxants. Am. Fam. Physician 44, 1223-1226.

Enz, R., Brandstatter, J. H., Hartveit, E., Wassle, H., Bormann, J., 1995. Expression of GABA receptor rho 1 and rho 2 subunits in the retina and brain of the rat. Eur. J. Neurosci. 7, 14951501.

Ewing, J. A., Fullilove, R. E., 1957. Addiction to meprobamate. N. Engl. J. Med. 257, 76-77.

Feng, H. J., Bianchi, M. T., Macdonald, R. L., 2004. Pentobarbital differentially modulates alpha1beta3delta and alpha1beta3gamma2L GABAA receptor currents. Mol. Pharmacol. 66, 988-1003. 
Gonzalez, L. A., Gatch, M. B., Forster, M. J., Dillon, G. H., 2009a. Abuse Potential of Soma: the GABA(A) Receptor as a Target. Mol. Cell. Pharmacol. 1, 180-186.

Gonzalez, L. A., Gatch, M. B., Taylor, C. M., Bell-Horner, C. L., Forster, M. J., Dillon, G. H., 2009b. Carisoprodol-mediated modulation of GABAA receptors: in vitro and in vivo studies. J. Pharmacol. Exp. Ther. 329, 827-837.

Greenblatt, D. J., Shader, R. I., 1974. Drug therapy. Benzodiazepines (second of two parts). N. Engl. J. Med. 291, 1239-1243.

Griebel, G., Perrault, G., Simiand, J., Cohen, C., Granger, P., Depoortere, H., Francon, D., Avenet, P., Schoemaker, H., Evanno, Y., Sevrin, M., George, P., Scatton, B., 2003. SL651498, a GABAA receptor agonist with subtype-selective efficacy, as a potential treatment for generalized anxiety disorder and muscle spasms. CNS Drug Rev. 9, 3-20.

Hamouda, A. K., Stewart, D. S., Chiara, D. C., Savechenkov, P. Y., Bruzik, K. S., Cohen, J. B., 2014. Identifying barbiturate binding sites in a nicotinic acetylcholine receptor with [3H]allyl m-trifluoromethyldiazirine mephobarbital, a photoreactive barbiturate. Mol. Pharmacol. 85, 735-746.

Hawkinson, J. E., Drewe, J. A., Kimbrough, C. L., Chen, J. S., Hogenkamp, D. J., Lan, N. C., Gee, K. W., Shen, K. Z., Whittemore, E. R., Woodward, R. M., 1996. 3 alpha-Hydroxy-3 betatrifluoromethyl-5 alpha-pregnan-20-one (Co 2-1970): a partial agonist at the neuroactive steroid site of the gamma-aminobutyric acidA receptor. Mol. Pharmacol. 49, 897-906.

Hendley, C. D., Lynes, T. E., Berger, F. M., 1954. Effect of 2-methyl, 2-n-propyl-1,3-propanediol dicarbamate (Miltown) on central nervous system. Proc. Soc. Exp. Biol. Med. 87, 608-610.

Hollister, L. E., Levy, G., 1964. Kinetics of Meprobamate Elimination in Humans. Chemotherapy 9, 20-24.

Horne, A.L., Harkness, P.C., Hadingham, H.L., Whiting, P., Kemp, J.A., 1993. The influence of the gamma2L subunit of the modulation of responses to GABAA receptor activation. $\mathrm{Br}$. J. Pharmacol. 108, 711-716. 
Hosie, A.M., Wilkins, M.E., da Silva, H.M.A., Smart, T.G. ,2006. Endogenous steroids regulate GABAA receptors through two distinct transmembrane sites. Nature 444, 486-489.

Kumar, M., Freund, J., Dillon, G. H., 2013. GABAA receptor subunit domains that confer carisoprodol sensitivity. Soc. Neurosci. Abst., 319.37/D27.

Kumar, M., Gonzalez, L. A., Dillon, G. H., 2015. Assessment of subunit-dependent direct gating and allosteric modulatory effects of carisoprodol at GABAA receptors. Neuropharmacology 97, 414-425.

Licata, S. C., Rowlett, J. K., 2008. Abuse and dependence liability of benzodiazepine-type drugs: GABA(A) receptor modulation and beyond. Pharmacol. Biochem. Behav. 90, 74-89.

Littrell, R. A., Hayes, L. R., Stillner, V., 1993. Carisoprodol (Soma): a new and cautious perspective on an old agent. South Med. J 86, 753-756.

Ludwig, B.J., Powell, L.S., Berger, F.M., 1969. Carbamate derivatives related to meprobamate. J. Med. Chem. 12, 462-474.

Low, K., Crestani, F., Keist, R., Benke, D., Brunig, I., Benson, J. A., Fritschy, J. M., Rulicke, T., Bluethmann, H., Mohler, H., Rudolph, U., 2000. Molecular and neuronal substrate for the selective attenuation of anxiety. Science 290, 131-134.

Maddock, R. K., Jr., Bloomer, H. A., 1967. Meprobamate overdosage. Evaluation of its severity and methods of treatment. J. A. M. A. 201, 999-1003.

Mistry, D. K., Cottrell, G. A., 1990. Actions of steroids and bemegride on the GABAA receptor of mouse spinal neurones in culture. Exp. Physiol. 75, 199-209.

Olsen, H., Koppang, E., Alvan, G., Morland, J., 1994. Carisoprodol elimination in humans. Ther. Drug Monit. 16, 337-340.

Olsen, R. W., Sieghart, W., 2008. International Union of Pharmacology. LXX. Subtypes of gammaaminobutyric acid(A) receptors: classification on the basis of subunit composition, pharmacology, and function. Update. Pharmacol. Rev. 60, 243-260. 
Pritchett, D. B., Sontheimer, H., Shivers, B. D., Ymer, S., Kettenmann, H., Schofield, P. R., Seeburg, P. H., 1989. Importance of a novel GABAA receptor subunit for benzodiazepine pharmacology. Nature 338, 582-585.

Reeves, R. R., Parker, J. D., 2003. Somatic dysfunction during carisoprodol cessation: evidence for a carisoprodol withdrawal syndrome. J. Am. Osteopath. Assoc. 103, 75-80.

Rho, J. M., Donevan, S. D., Rogawski, M. A., 1997. Barbiturate-like actions of the propanediol dicarbamates felbamate and meprobamate. J. Pharmacol. Exp. Ther. 280, 1383-1391.

Rudolph, U., Mohler, H., 2014. GABAA receptor subtypes: Therapeutic potential in Down syndrome, affective disorders, schizophrenia, and autism. Annu. Rev. Pharmacol. Toxicol. 54, 483-507.

Rust, G. S., Hatch, R., Gums, J. G., 1993. Carisoprodol as a drug of abuse. Arch Fam Med 2, 429432.

Schechter, M. D., 1984. Specific antagonism of the behavioral effects of chlordiazepoxide and pentobarbital in the rat. Prog Neuropsychopharmacol. Biol. Psych. 8, 359-364.

Sullivan, M. D., 2015. What are we treating with opioid and sedative-hypnotic combination therapy? Pharmacoepidemiol. Drug Saf. 24, 893-895.

Tan, K. R., Brown, M., Labouebe, G., Yvon, C., Creton, C., Fritschy, J. M., Rudolph, U., Luscher, C., 2010. Neural bases for addictive properties of benzodiazepines. Nature 463, 769-774.

Toth, P. P., Urtis, J., 2004. Commonly used muscle relaxant therapies for acute low back pain: a review of carisoprodol, cyclobenzaprine hydrochloride, and metaxalone. Clin. Ther. 26, $1355-1367$.

van Rijnsoever, C., Tauber, M., Choulli, M. K., Keist, R., Rudolph, U., Mohler, H., Fritschy, J. M., Crestani, F., 2004. Requirement of alpha5-GABAA receptors for the development of tolerance to the sedative action of diazepam in mice. J. Neurosci. 24, 6785-6790. 
Wagoner, K. R., Czajkowski, C., 2010. Stoichiometry of expressed alpha(4)beta(2)delta gammaaminobutyric acid type A receptors depends on the ratio of subunit cDNA transfected. J. Biol. Chem. 285, 14187-14194.

Witenko, C., Moorman-Li, R., Motycka, C., Duane, K., Hincapie-Castillo, J., Leonard, P., Valaer, C., 2014. Considerations for the appropriate use of skeletal muscle relaxants for the management of acute low back pain. P. T. 39, 427-435.

Wohlfarth, K. M., Bianchi, M. T., Macdonald, R. L., 2002. Enhanced neurosteroid potentiation of ternary GABA(A) receptors containing the delta subunit. J. Neurosci. 22, 1541-1549.

Zacny, J. P., Paice, J. A., Coalson, D. W., 2011. Characterizing the subjective and psychomotor effects of carisoprodol in healthy volunteers. Pharmacol. Biochem. Behav. 100, 138-143.

Zacny, J. P., Paice, J. A., Coalson, D. W., 2012. Subjective and psychomotor effects of carisoprodol in combination with oxycodone in healthy volunteers. Drug. Alcohol Depend. 120, 229232. 
Table 1. GABA sensitivity of the $\mathrm{GABA}_{\mathrm{A}}$ receptor subunit configurations studied. $\mathrm{EC}_{50}$ values for each receptor are expressed as mean \pm S.E.M. 


\begin{tabular}{|c|c|c|}
\hline $\begin{array}{c}\text { Receptor } \\
\text { Configuration }\end{array}$ & $\mathrm{EC}_{50}(\boldsymbol{\mu M})$ & $\mathbf{n}$ \\
\hline$\alpha 1 \beta 2$ & $16.4 \pm 2.39$ & 5 \\
\hline$\alpha 1 \beta 2 \gamma 2$ & $28.6 \pm 2.75$ & 8 \\
\hline$\alpha 2 \beta 2 \gamma 2$ & $32.8 \pm 1.81$ & 5 \\
\hline$\alpha 3 \beta 2 \gamma 2$ & $34.8 \pm 2.09$ & 8 \\
\hline$\alpha 4 \beta 2 \gamma 2$ & $5.9 \pm 0.16$ & 5 \\
\hline$\alpha 5 \beta 2 \gamma 2$ & $0.8 \pm 0.23$ & 4 \\
\hline$\alpha 6 \beta 2 \gamma 2$ & $1.7 \pm 0.24$ & 4 \\
\hline$\alpha 1 \beta 1 \gamma 2$ & $15.7 \pm 0.15$ & 7 \\
\hline$\alpha 4 \beta 3 \delta$ & $0.04 \pm 0.02$ & 4 \\
\hline
\end{tabular}


Figure 1. Structure of meprobamate and a prominent parent molecule, carisoprodol. The molecules differ by an isopropyl present on one of carisoprodol's carbamyl nitrogens; the isopropyl is removed by CYP2C19 to form meprobamate. 

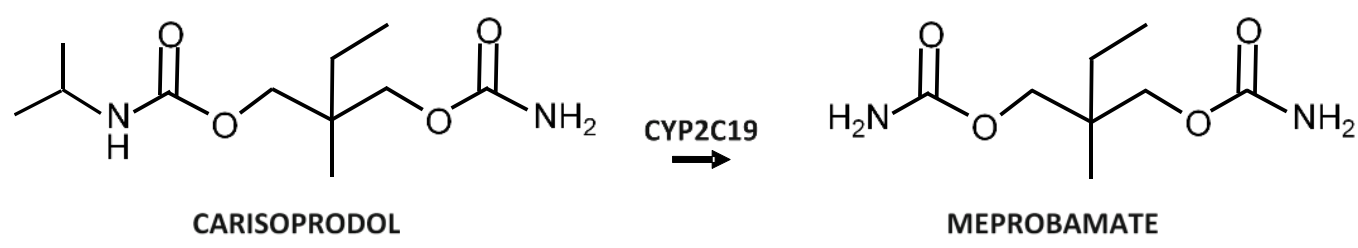
Figure 2. Assessment of subunit-dependent effects of meprobamate on direct activation of $\mathbf{G A B A}_{\mathbf{A}}$ receptors. A, Representative traces demonstrating direct activation by meprobamate in $\alpha 1 \beta 2 \gamma 2, \alpha 3 \beta 2 \gamma 2, \alpha 1 \beta 2$ and $\alpha 1 \beta 1 \gamma 2$ receptors. $\mathbf{B}, \mathbf{C}$ and $\mathbf{D}$, summary data of meprobamate mediated direct-gating effects associated with varying $\alpha, \gamma$ and $\beta$ subunits, respectively. Direct activation capability was diminished in $\alpha 3 \beta 2 \gamma 2$ compared to the other configurations, whereas varying the $\beta$ subunit or deleting the $\gamma 2$ subunit had negligible effects. Each data point represents the mean \pm S.E.M. of a minimum of 4 cells. $*, p<0.05 ; * *, p<$ 0.01 . 
A

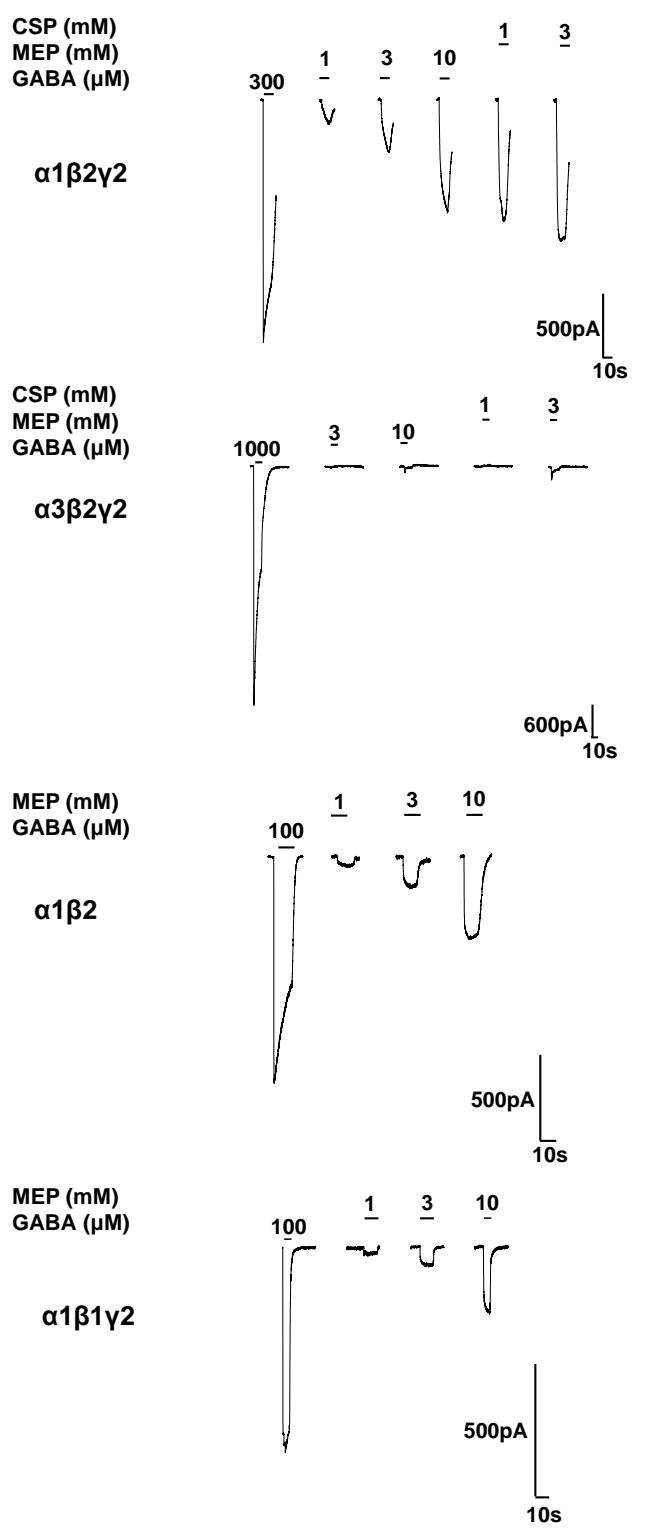

B

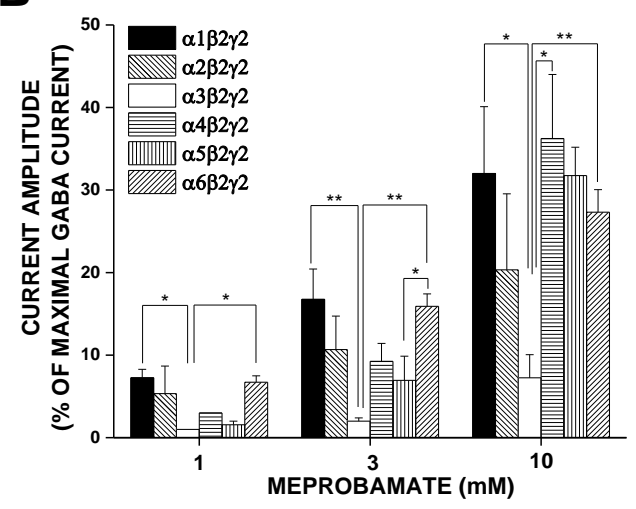

C

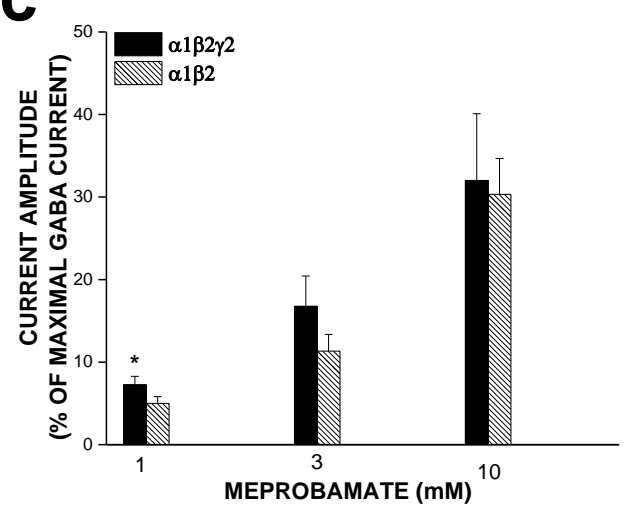

D

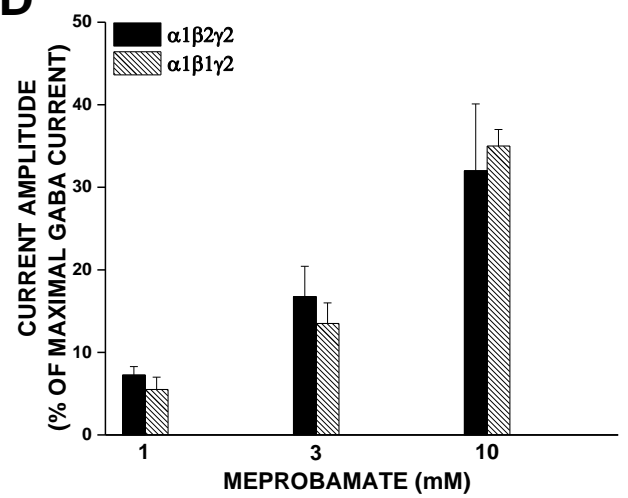


Figure 3. Assessment of subunit-dependent effects of allosteric modulatory effects of meprobamate on $\mathrm{GABA}_{\mathrm{A}}$ receptors. A, Representative traces demonstrating direct allosteric potentiation by meprobamate of GABA-gated $\left(\mathrm{EC}_{20}\right)$ currents in $\alpha 1 \beta 2 \gamma 2, \alpha 3 \beta 2 \gamma 2, \alpha 1 \beta 2$ and $\alpha 1 \beta 1 \gamma 2$ receptors. $\mathbf{B}, \mathbf{C}$ and $\mathbf{D}$, summary data of allosteric effects of meprobamate associated with varying $\alpha, \gamma$ and $\beta$ subunits, respectively. Allosteric potentiation was present in all $\alpha \beta \gamma$ receptors, but greatest in those expressing the $\alpha 5$ subunit; absence of the $\gamma$ subunit also resulted in enhanced potentiation. Note for this and other figures assessing allosteric modulation, underlying direct gating effects were subtracted out for calculation of summary data. Each data point represents the mean \pm S.E.M. of a minimum of 4 cells. $*, p<0.05 ; * * *, p<0.001$. 
A
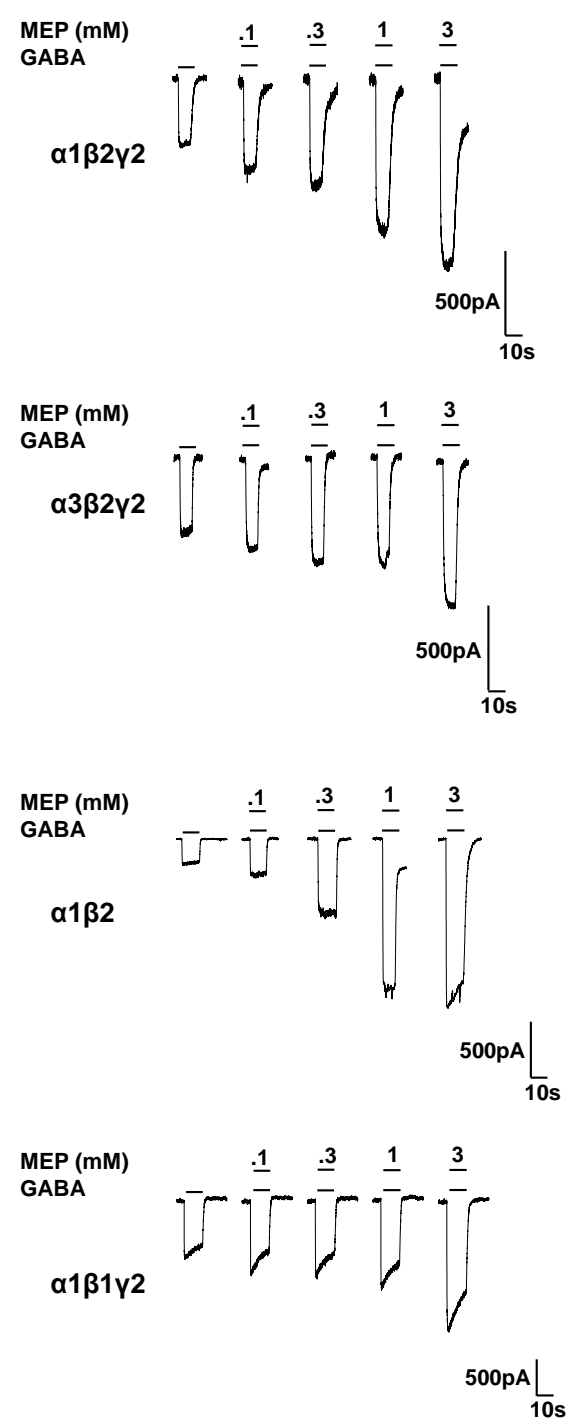

B
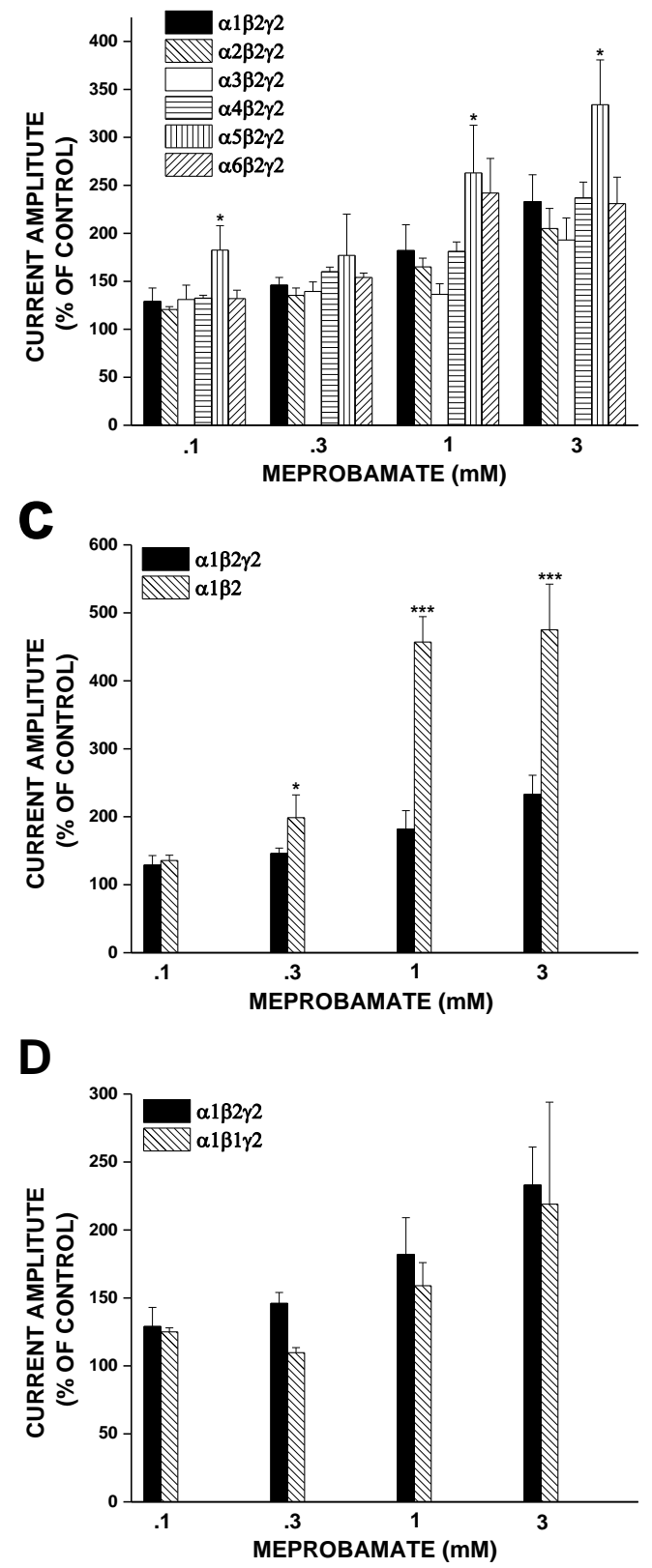
Figure 4. Assessment of direct gating effects of meprobamate in extrasynaptic GABA receptors. A, representative traces demonstrating meprobamate direct gating action on $\alpha 4 \beta 3 \delta$ and $\alpha 1 \beta 3 \delta \mathrm{GABA}_{\mathrm{A}}$ receptors, in comparison to a saturating concentration of GABA. The maximal efficacy of meprobamate was comparable to that of GABA. B, Summary data illustrating the efficacy of meprobamate compared to GABA in $\alpha 1 \beta 2, \alpha 1 \beta 2 \gamma 2, \alpha 1 \beta 3 \delta$ and $\alpha 4 \beta 3 \delta \mathrm{GABA}_{\mathrm{A}}$ receptor. Data for $\alpha 1 \beta 2$ and $\alpha 1 \beta 2 \gamma 2$ receptors are re-plotted from Figure 1 for comparison. Efficacy of the full agonist THIP was also assessed; it was significantly more efficacious than either GABA or meprobamate on $\delta$-containing $\mathrm{GABA}_{\mathrm{A}}$ receptors. Each bar represents the mean \pm S.E.M. of a minimum of 3 cells for $\delta$-containing receptors, and mean \pm S.E.M. of a minimum of 4 for all others. ${ }^{*}, p<0.05 ; * *, p<0.01$. 
A

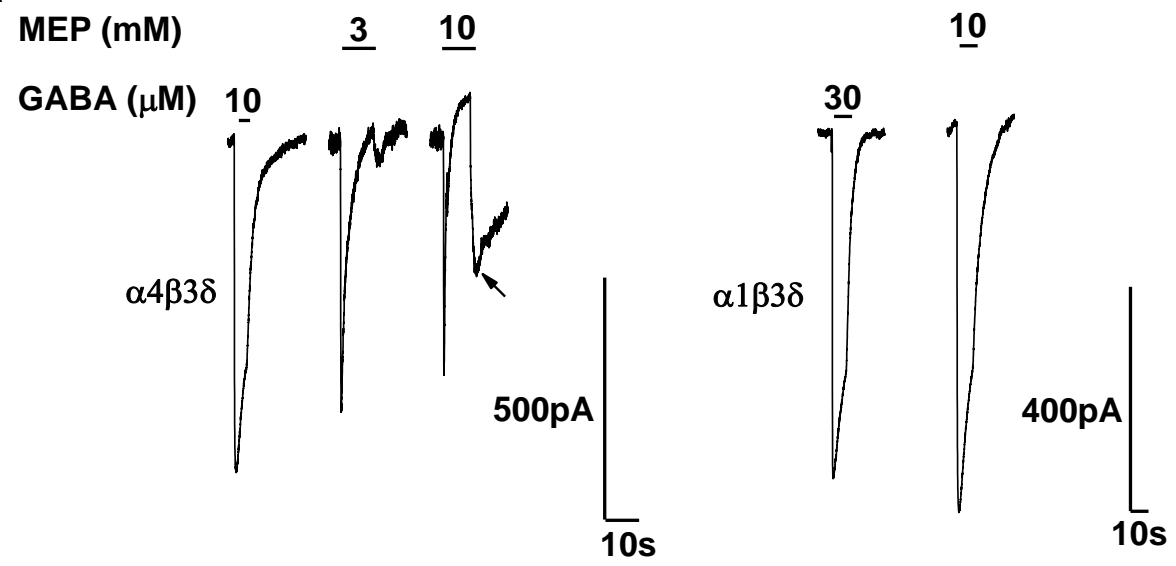

B

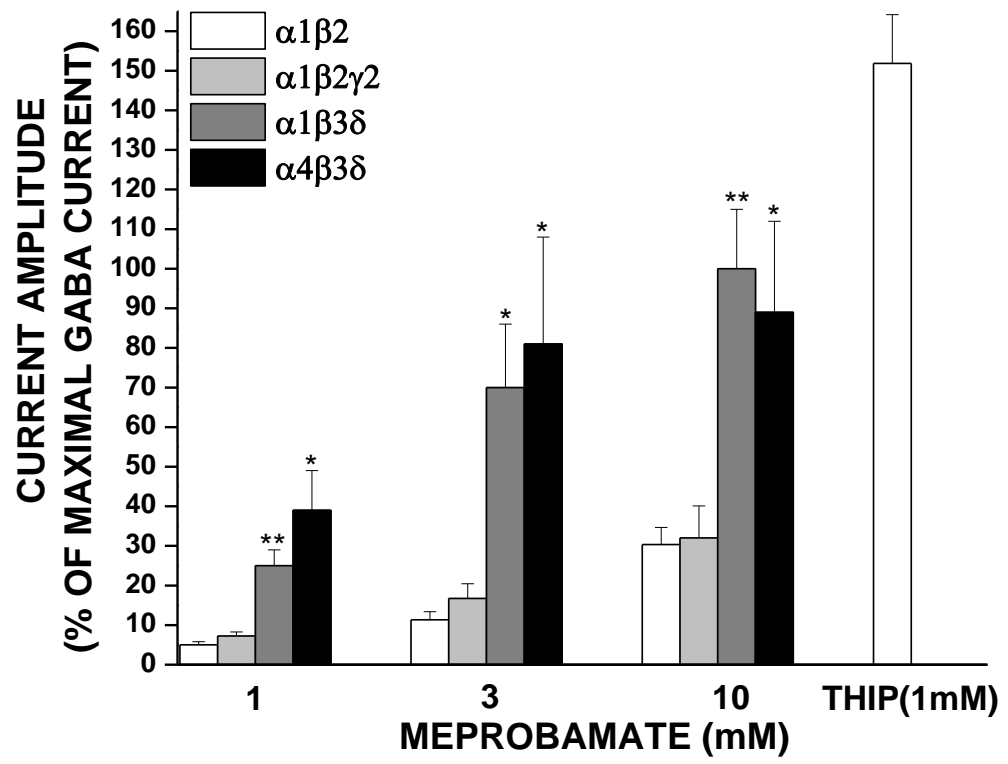


Figure 5. Assessment of allosteric effects of meprobamate in extrasynaptic receptors. A, representative traces demonstrating the potentiation by meprobamate of GABA-gated $\left(\mathrm{EC}_{20}\right)$ currents in $\alpha 4 \beta 3 \delta \mathrm{GABA}_{\mathrm{A}}$ receptors. B, Bar graph summarizing the concentration-response profile for the allosteric modulatory effects of meprobamate on extrasynaptic $\alpha 4 \beta 3 \delta \mathrm{GABA}_{\mathrm{A}}$ receptors. Each bar represents the mean \pm S.E.M. of a minimum of 3 cells. 
A

$\begin{array}{lllll}M E P(m M) & .1 & \underline{3} & 1 & \underline{3}\end{array}$
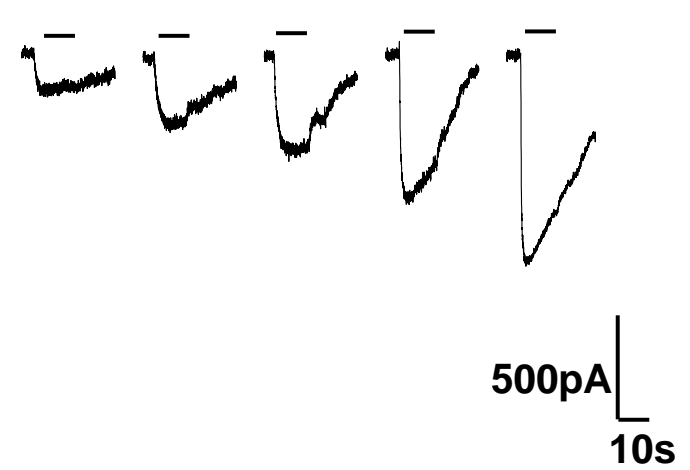

B

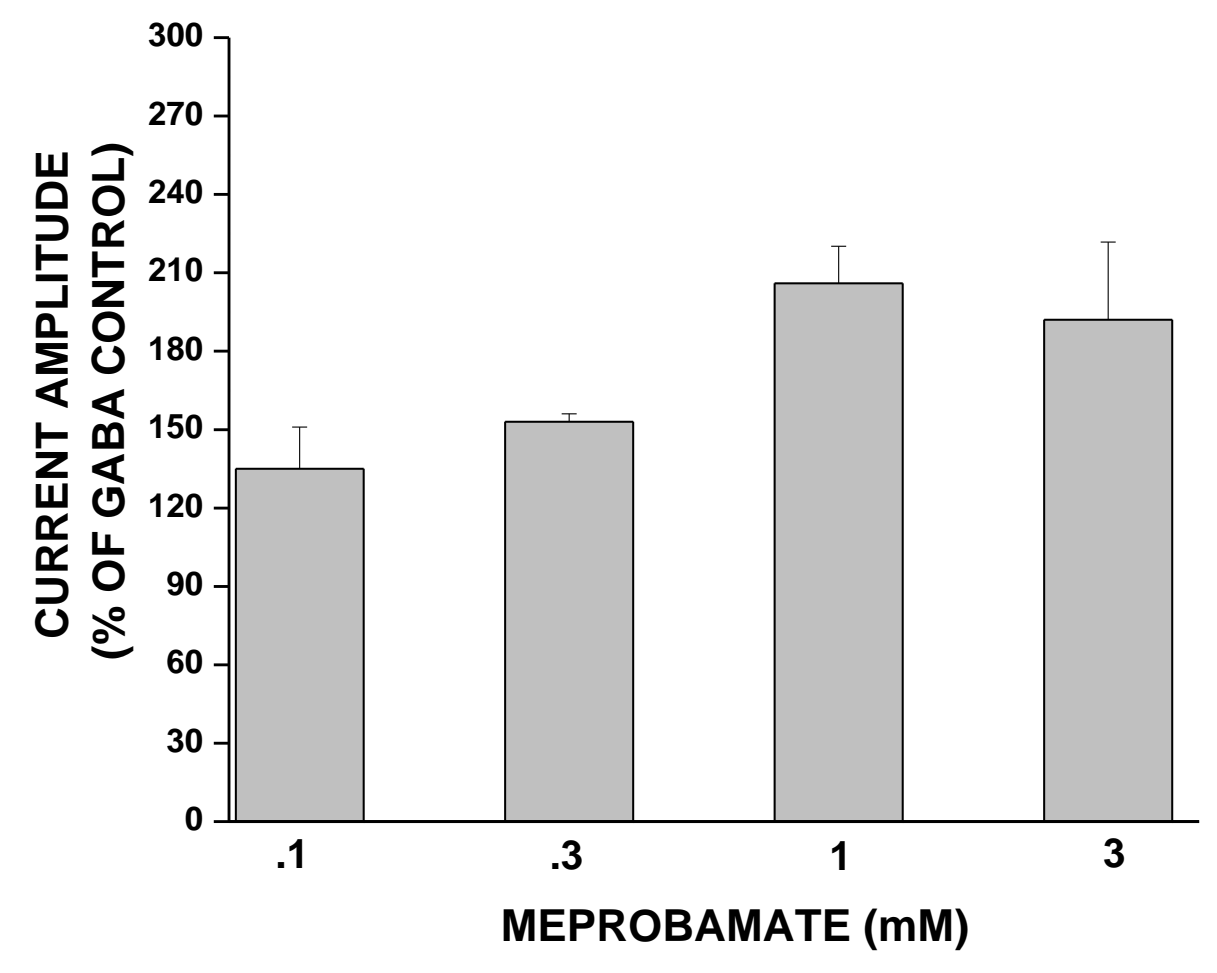


Figure 6. Potentiation of maximal GABA by meprobamate in extrasynaptic receptors. A, Illustrative traces showing that in both $\alpha 4 \beta 3 \delta$ and $\alpha 1 \beta 3 \delta$ extrasynaptic $\mathrm{GABA}_{\mathrm{A}}$ receptors, $1 \mathrm{mM}$ meprobamate significantly enhanced the magnitude of a saturating concentration of GABA alone, whereas this potentiation was not observed in $\alpha 1 \beta 3$ or $\alpha 1 \beta 2 \gamma 2$ receptors. $\mathbf{B}$, Summary data illustrating potentiation of maximal GABA current by both pentobarbital and meprobamate in $\delta$-subunit expressing receptors, compared to those not expressing the $\delta$ subunit. Data are expressed relative to the peak current amplitude elicited by saturating concentration of GABA. Each bar represents the mean \pm S.E.M. of a minimum of 3 cells for $\delta$-containing receptors, and mean \pm S.E.M. of a minimum of 4 for all others. ${ }^{* *}, p<0.01$. 
A

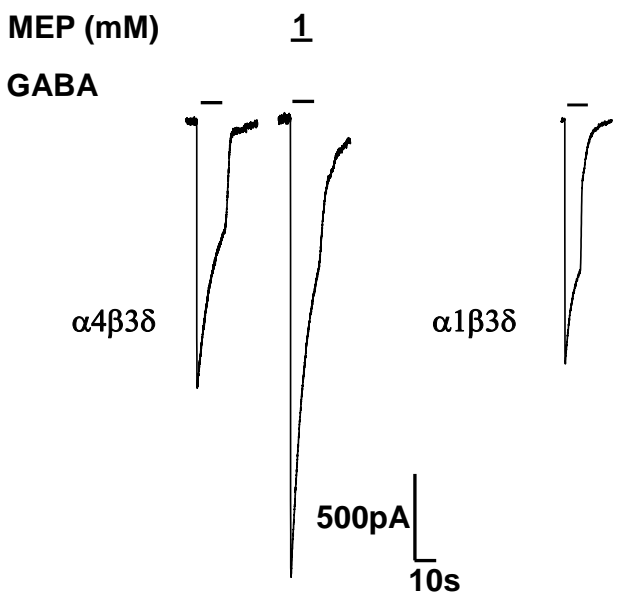

1

MEP (mM)

1

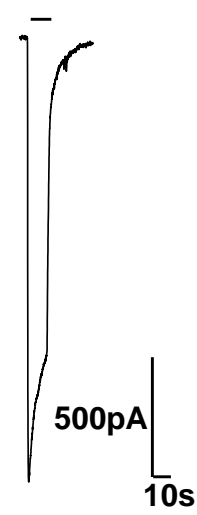

GABA
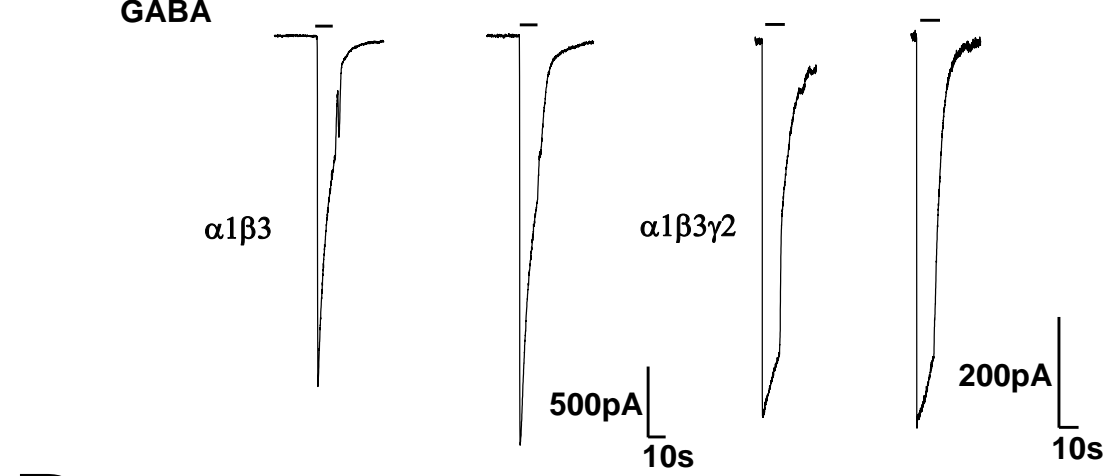

1

B

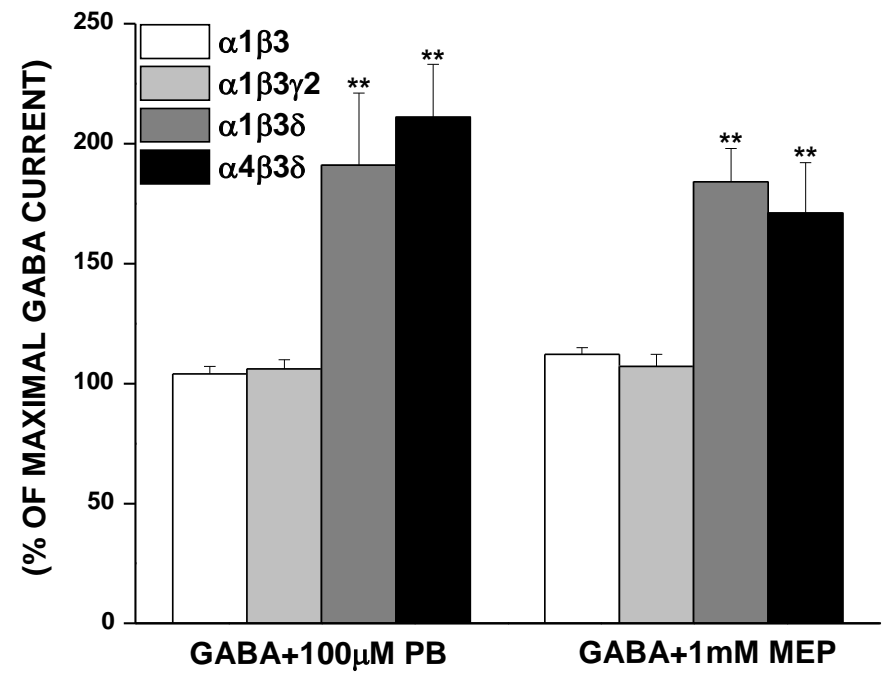


Figure 7. Assessment of "barbiturate-like" actions of meprobamate. A, top, representative traces demonstrating meprobamate-activated currents are reversibly reduced in the presence of the barbiturate antagonist bemegride in stably expressed human $\alpha 1 \beta 2 \gamma 2$ receptors. A, middle, Neither pentobarbital nor meprobamate could directly gate wild type homomeric $\rho 1$ receptors; the W328M mutation conferred sensitivity to pentobarbital, but not meprobamate. A, bottom, Pentobarbital directly gated homomeric $\beta 3$ receptors, whereas meprobamate blocked the spontaneously open current present in these channels. B, Summary results for experiments presented in panel A. Each data point represents the mean \pm S.E.M. of a minimum of 4 cells for all data sets. *, $p<0.05 ;{ }^{* *}, p<0.01 ; * * *, p<0.001 ; \#, \mathrm{p}<0.05$ compared to the $3 \mathrm{mM}$ MEP effect, illustrating a concentration-dependent effect of bemegride. 
A

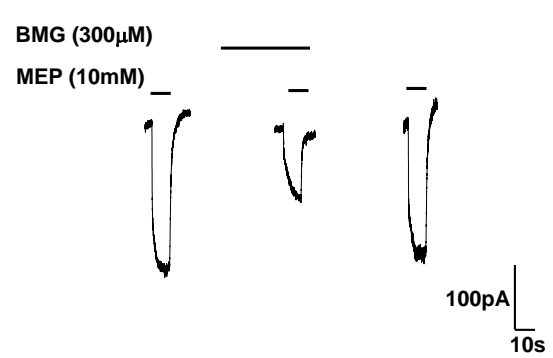

B
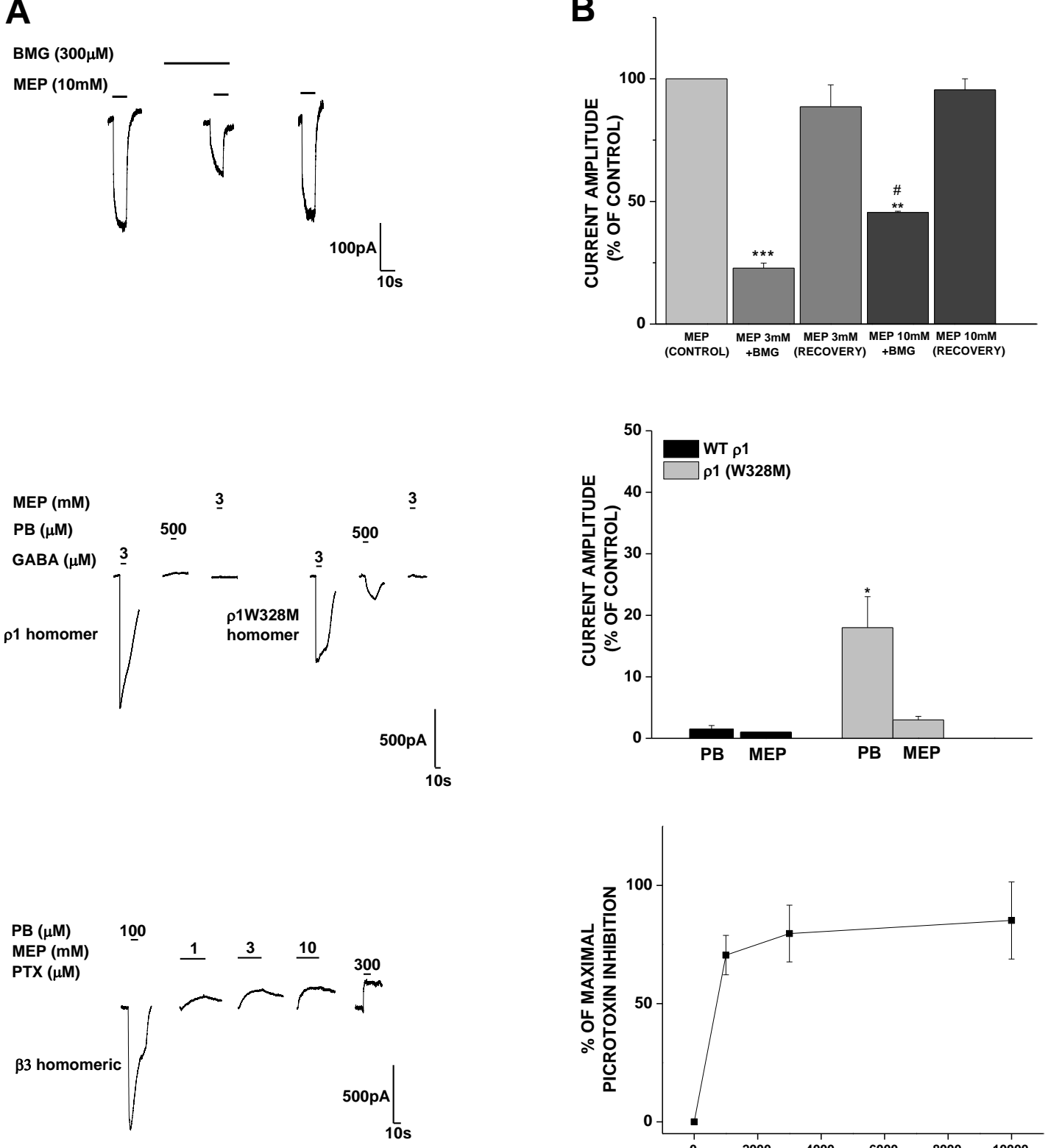

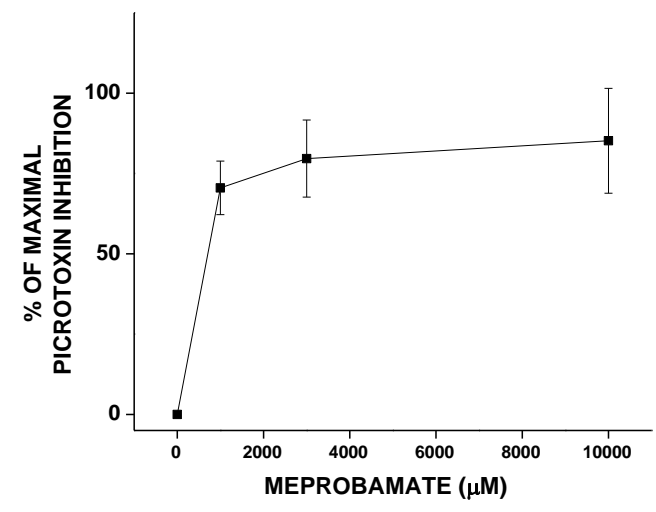




\section{CHAPTER III}




\title{
ASSESSMENT OF GABAA RECEPTORS TM4 AND TM2 AMINO ACID RESIDUES IN DIRECT
}

GATING AND INHIBITORY EFFECTS OF CARISOPRODOL AND MEPROBAMATE

\author{
Manish Kumar ${ }^{1}$, Manoj Kumar and Glenn H. Dillon ${ }^{1,2}$
}

Department of Physiology and Pharmacology and Center for Neuroscience,

Robert C. Byrd Health Sciences Center, West Virginia University, Morgantown, WV ${ }^{1}$ and Center for Neuroscience Discovery, University of North Texas Health Science

Center, Fort Worth, $\mathrm{TX}^{2}$

Corresponding author: Glenn H. Dillon, Ph.D.

Center for Neuroscience Discovery, Institute for Healthy

Aging

University of North Texas Health Science Center

Fort Worth, TX 76107

Phone: $\quad$ (817)-735-2427

E-mail: $\quad$ glenn.dillon@unthsc.edu 


\begin{abstract}
Meprobamate (tradenames Miltown, Equanil) is a schedule IV anxiolytic and the primary metabolite of the muscle relaxant carisoprodol. Though it used to be a widely prescribed tranquilizer, a thorough understanding of its direct-gating, allosteric-modulation and inhibitory effects remains ill-defined. Meprobamate modulates $\mathrm{GABA}_{\mathrm{A}}(\gamma$-aminobutyric acid type A) receptors, and has been described as having a barbiturate-like activity. In previous reports, we found that in comparison to $\alpha 1 \beta 2 \gamma 2$ receptors, $\alpha 3 \beta 2 \gamma 2$ receptors had attenuated direct gating effects for both meprobamate and carisoprodol. Here, using site-directed-mutagenesis and whole cell patch clamp electrophysiology in transiently transfected HEK293 cells, we examined the role of $\mathrm{GABA}_{\mathrm{A}}$ receptor $\alpha$-subunit transmembrane domain 4 (TM4) amino acids in direct gating actions of meprobamate, and transmembrane domain 2 (TM2) amino acids in inhibitory actions of meprobamate and carisoprodol. Mutation of $\alpha 3$ valine at position t440 to leucine (present in the equivalent position in the $\alpha 1$ subunit) increased the direct gating potency and efficacy of meprobamate. In $\alpha 1 \beta 2$ heteromeric $\mathrm{GABA}_{\mathrm{A}}$ receptors, both pentobarbital and carisoprodol had inhibitory effect for allosteric modulatory action at higher concentrations. Meprobamate did not have an inhibitory effect at the concentrations tested. T6'F mutation of the $\beta 2$-subunit abolished the inhibition of carisoprodol but not of pentobarbital. Thus, our studies provide further insight into molecular determinants of actions of meprobamate, its parent drug carisoprodol and their comparison to barbiturate pentobarbital.
\end{abstract}

Key words: $\mathrm{GABA}_{\mathrm{A}}$ receptor; meprobamate; carisoprodol; muscle relaxant; drug abuse 


\section{Introduction}

$\mathrm{GABA}_{\mathrm{A}}$ receptors are members of cys-loop ligand-gated ion channel superfamily. Other members of this group are glycine, acetylcholine receptor, GABAC receptors, serotonin

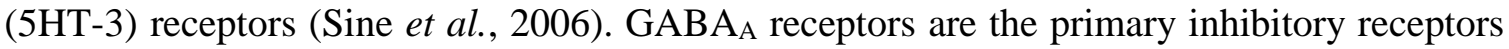
of the CNS (Bormann, 2000). Upon activation, opening of chloride channels and chloride ion entry, lead to the development of inhibitory post-synaptic potential (IPSP) (Bormann, 2000).

$\mathrm{GABA}_{\mathrm{A}}$ receptors are pentameric in nature. Each of the subunits are composed of a long extracellular $\mathrm{N}$-terminal domain, a short C-terminal domain, 4 transmembrane domains (TM1-TM4), an extracellular TM2-TM3 loop and two intracellular loops, a large TM3-TM4 and a short TM1-TM2 loop (Cockcroft et al., 1995). TM2 of all the 5 subunits make the pore of the channel (Xu et al., 1996; Miyazawa et al., 2003). Some inhibitors of GABA receptors interact with amino acids constituting TM2 loop (Gurley et al., 1995). GABA receptors are seats of action of many inhibitory ligands like benzodiazepines, barbiturates, neuro-steroids and muscle relaxants like carisoprodol and meprobamate (Gonzalez et al., 2009b; Rudolph et al., 2011; Kumar et al., 2015)

Meprobamate, used to be a widely prescribed tranquilizer, anti-convulsant and muscle relaxant (Hendley et al., 1954; DeLong et al., 1985). Within few years of its introduction, cases of abuse and physical and psychological dependence started piling up (Ewing et al., 1957). So it was made a controlled substance (schedule IV) at the federal level. While meprobamate was made a controlled substance, drugs metabolized to meprobamate are widely available. One such drug is the muscle relaxant carisoprodol whose easy availability due to internet pharmacies, has made it a widely abused drug (Toth et al., 2004; Sullivan, 2015). There have been many cases of abuse, dependence and in some cases even death due to carisoprodol toxicity (Adams et al., 1975; Elder, 1991; Littrell et al., 1993; Rust et al., 1993; Reeves et al., 
2003; Zacny et al., 2011; Zacny et al., 2012). Although carisoprodol can have independent action (Gonzalez et al., 2009b), a significant portion of its action and abuse is due to meprobamate. As much of the research done on meprobamate has been in the years prior and during its major use, its detailed mechanism of action is not clear. It was shown to act on $\mathrm{GABA}_{\mathrm{A}}$ receptors in a barbiturate like manner (Rho et al., 1997). Our lab has shown meprobamate to have both direct-gating and allosteric modulatory effect on all synaptic and extra-synaptic $\mathrm{GABA}_{\mathrm{A}}$ receptors subunit combinations. For direct-gating, meprobamate and carisoprodol, had maximum effect on $\alpha 1$ containing receptor while $\alpha 3$ had the least effect (Kumar et al., 2015)(Kumar et al. 2016, in press). TM1-TM3 are fully conserved between $\alpha 1$ and $\alpha 3$ subunits. However, amino acids I419, I423 and V440 of TM4 of $\alpha 3$ are different from that of $\alpha 1$ subunit (Barnard et al., 1998; Bergmann et al., 2013). Here we tested the hypothesis, how this difference in the amino-acid compositions between $\alpha 3$ and $\alpha 1$ is responsible for the difference in the direct gating actions on the two subunits.

High concentrations of carisoprodol and pentobarbital had inhibitory effects for allosteric modulatory action in $\mathrm{GABA}_{\mathrm{A}}$ receptor. TM2 T6' residue of the $\beta$-subunit of glycine receptor, has been implicated in the blocking action of picrotoxin (Pribilla et al., 1992). Later it was also shown to be critical in the picrotoxin blocking action in $\mathrm{GABA}_{\mathrm{A}}$ (Gurley et al., 1995)and $\rho 1 \mathrm{GABA}_{C}$ receptors (Zhang et al., 1995). T6'F mutation has been known to cause a significant reduction in picrotoxin inhibitory effect without abolishing it completely (Shan et al., 2001; Sedelnikova et al., 2006). This residue has been shown to be involved in blocking effects of other ligands of $\mathrm{GABA}_{\mathrm{A}}$ receptors. We tested the hypothesis that T6' residue is also implicated in the blocking action of carisoprodol and pentobarbital. 


\section{Materials and Methods}

\subsection{Cell Culture and Transfection}

Human embryonic kidney 293 (HEK293) cells transiently expressing varying GABA A receptor subunits, were used in the present study. For transient transfection, cells were transfected with human GABAA $\alpha$; human $\beta$; and human $\gamma 2$ s (short isoform) cDNA in a 1:1:5 ratio $\left(2 \mu \mathrm{g}\right.$ total cDNA) using PolyJet ${ }^{\mathrm{TM}}$ in vitro transfection reagent (SignaGen Laboratories, Jamesville, MD). The $\gamma 2$ s subunit will be referred to as $\gamma 2$ from here forth. Human GABAA $\alpha 1$ subunit cDNA was generously provided by Neil Harrison (Columbia University Medical Center, New York). Rat $\alpha 1$ and $\beta 2$ subunits were also used. Transfection using just the $\alpha$ and

$\beta$ subunits were made using the plasmids in ratio $1: 1$ with a total of $2 \mu \mathrm{g}$ of $\mathrm{cDNA}^{\text {. PolyJet }}{ }^{\mathrm{TM}}$ in vitro transfection reagent was used $3 \mu \mathrm{l} / \mu \mathrm{g}$ of DNA. Cells were plated on glass coverslips coated with poly-L-lysine in $35-\mathrm{mm}$ culture dishes, and maintained at $37^{\circ} \mathrm{C}$ in a humidified incubator with an atmosphere of 5\% CO2 In all cases, cells were used for recording 24-72 hours after transfection.

\subsection{Electrophysiology}

Whole-cell patch clamp electrophysiology was used to assess GABA-, meprobamateor pentobarbital-activated $\mathrm{Cl}^{-}$currents. All electrophysiology experiments were conducted at room temperature $\left(22-25^{\circ} \mathrm{C}\right)$ with the membrane potential clamped at $-60 \mathrm{mV}$. Patch pipettes of borosilicate glass (1B150F; World Precision Instruments, Inc., Sarasota, FL) were pulled (Flaming/Brown, P-87/PC; Sutter Instrument Company, Novato, CA) to a tip resistance of 4$6 \mathrm{M} \Omega$. Patch pipettes were filled with a solution consisting of $140 \mathrm{mM} \mathrm{CsCl}, 10 \mathrm{mM}$ EGTA$\mathrm{Na}^{+}, 10 \mathrm{mM}$ HEPES-Na ${ }^{+}$, and $4 \mathrm{mM} \mathrm{Mg}{ }^{2+}$-ATP, $\mathrm{pH}$ 7.2. Coverslips containing cultured cells were placed in the recording chamber on the stage of an inverted light microscope and 
superfused continuously with an external solution consisting of $125 \mathrm{mM} \mathrm{NaCl}, 20 \mathrm{mM}$ HEPES, $3 \mathrm{mM} \mathrm{CaCl} 2,5.5 \mathrm{mM} \mathrm{KCl}, 0.8 \mathrm{mM} \mathrm{MgCl}$, and $10 \mathrm{mM}$ glucose, $\mathrm{pH}$ 7.3. Agonist-induced $\mathrm{Cl}^{-}$ currents were obtained with an Axopatch 200B amplifier (Molecular Devices, Sunnyvale, CA) equipped with a CV-203BU headstage. Currents were low-pass filtered at $5 \mathrm{kHz}$, monitored simultaneously on an oscilloscope and a chart recorder (Gould TA240; Gould Instrument Systems Inc., Cleveland, $\mathrm{OH}$ ), and stored on a computer using an on-line data acquisition system (pCLAMP 6.0; Axon Instruments) for subsequent off-line analysis.

\subsection{Chemicals and solutions}

Meprobamate, carisoprodol, pentobarbital, diazepam, salts and buffers were purchased from Sigma Aldrich (St. Louis, MO). GABA was obtained from Acros Organics (New Jersey, US). Stock solutions of meprobamate, pentobarbital and carisoprodol were made using dimethylsulfoxide (DMSO). Drugs were diluted in normal saline, so that the final DMSO concentration ( $\mathrm{vol} / \mathrm{vol}$ ) of the test solutions was $\leq 0.3 \%$. GABA and diazepam stock solutions were prepared using de-ionized $\mathrm{H}_{2} \mathrm{O}$. All stock solutions were stored at $-20{ }^{\circ} \mathrm{C}$. On experimental days, drug-containing solutions were prepared from stock by serial dilution into external solution.

\subsection{Experimental Protocol}

GABA (with or without modulatory ligand), meprobamate, carisoprodol or pentobarbital were prepared in external solution on the day of use and applied via a 16-barrel rapid perfusion system in which all barrels $(200 \mu \mathrm{m}$ outer diameter quartz tubes; ALA Scientific, Folsom, CA) emptied via a common tip positioned adjacent to the cell under study. Flow through each barrel was pressure fed and regulated by solenoid or pinch valves operated by a programmable microprocessor-based controller. Only one valve was open at a time, and 
the buffer solution was applied continuously between drug applications via gravity or positive pressure. For some experiments, ligands were applied via gravity flow using a Y-tube placed adjacent to the cell.

The modulatory effects of meprobamate, pentobarbital or carisoprodol on GABAgated currents were assessed using an $\mathrm{EC}_{20}$ gating concentration of GABA as the control. This gating concentration was selected to ensure there was a sufficient range to observe the full allosteric potential of meprobamate. To ensure the gating concentration was approximately an EC20, control responses were compared to the maximal GABA-gated current for each individual cell. On a cell by cell basis, control GABA currents were deemed acceptable for assessment of allosteric modulatory effects of meprobamate if they were within a 15-25\% range of maximal current for that particular cell. Control responses were established by observing two consecutive agonist-activated currents that varied in amplitude by no more than $\pm 10 \%$. In our analyses of the modulatory effects of meprobamate, peak current amplitude was defined as the maximum current elicited by GABA. In all studies assessing direct gating effects, the magnitude of the response was expressed relative to the maximal effect of GABA (designated 100\%). For $\alpha \beta \gamma$ configurations, GABA-gated control currents were recorded in the presence of diazepam to confirm incorporation of the $\gamma 2$ subunit.

\subsection{Data Analysis}

To ensure equipotent concentrations were used for gating, GABA concentrationresponse data were collected. From these data, $\mathrm{EC}_{20}$ and saturating GABA concentrations were calculated for each configuration and used in subsequent investigations of the allosteric and direct effects, respectively. For studies assessing allosteric actions, a correction was applied to subtract underlying direct gating effects. All data are presented as mean values \pm S.E. Statistical significance $(p<0.05)$ between control and test conditions was determined using 
Student's $t$-test (paired or unpaired) and one-way analysis of variance. Tukey-Kramer post hoc test for multiple comparisons was performed as needed.

2.6 Plasmids and site-directed-mutagenesis

Human cDNA plasmids encoding $\alpha 1, \alpha 3, \beta 2$ and $\gamma 2$ GABAA receptor subunits were used in the present study. Individual and combined mutations in $\alpha 3$ cDNA plasmids were created using Stratagene's Quik Change II ${ }^{\circledR}$ site-directed-mutagenesis kit (Agilent Technologies; La Jolla, CA) and were sequenced to confirm mutations at West Virginia University’s Genomics Core Facility. 


\section{Results}

3.1 TM4 amino acid mutations $\alpha 3$ to corresponding $\alpha 1$, lead to an increased meprobamate mediated direct gating effect

On testing for the action of meprobamate on various subunit compositions of $\mathrm{GABA}_{\mathrm{A}}$ receptors, we found it to have maximum direct-gating effect on $\alpha 1$ and a significantly attenuated effect on $\alpha 3$ containing $\mathrm{GABA}_{\mathrm{A}}$ receptors. Further we saw the effect of meprobamate to be consistent with its action in the transmembrane region (Hosie et al., 2006). When we looked for difference in structure, amino-acid compositions of TM1-TM3 regions is conserved between $\alpha 1$ and $\alpha 3$ subunit isoforms. TM4 region is also largely conserved, except for, I420, I424 and V441 of $\alpha 3$, which differs from $\alpha 1$, which are L420, A424 and L441 (Barnard et al., 1998; Bergmann et al., 2013) (Fig.1). To test the roles of these amino acids unique to $\alpha 3$ in the attenuated direct gating effect, successive mutations were made to convert $\alpha 3$ to $\alpha 1$ either singly or in combination, using site directed mutagenesis. Mutations tested were, $\alpha 3$ (V441L), $\alpha 3$ (I420L/I424A) and $\alpha 3$ (I420L/I424A/ V441L). In order to assess the receptor function, GABA concentration response was done on each mutants. In general, the shift in GABA EC 50 was modest (Table 1). We observed an increase in direct gating efficacy for meprobamate in mutant receptors compared to WT $\alpha 3$ receptors, suggesting the role of above amino acids in different direct gating efficacy of $\alpha 3$ and $\alpha 1$ receptors.

3.2 Carisoprodol and pentobarbital, but not meprobamate show an inhibition and rebound at high concentrations in WT $\alpha 1 \beta 2 G A B A_{A}$ receptors 
At lower concentrations $(<100 \mu \mathrm{M})$, pentobarb, meprobamate and carisoprodol enhanced GABA mediated current in a concentration-dependent manner. At higher concentrations (>100 $\mu \mathrm{M}$ ), there was successive attenuation of GABA-mediated current by both pentobarb and carisoprodol. At $3 \mathrm{mM}$ a rebound or offshoot was observed on drug application termination (Fig 3A and 4A). Neither an attenuation nor rebound was observed with meprobamate at the concentrations tested (till $3 \mathrm{mM}$ ) (Fig. 5A). We may observe a similar effect for meprobamate at higher concentrations as it has shown approximately 3 times less sensitivity than carisoprodol in our previous reports.

3.3 T6' $F$ mutation in $\beta 2$ subunit, attenuates inhibition and rebound (offshoot) currents in carisoprodol, but not in pentobarital

Lower concentration of both pentobarb and carisoprodol enhanced GABA-mediated currents in WT $\alpha 1 \beta 2 \mathrm{GABA}_{\mathrm{A}}$ receptor. At concentrations $>100 \mu \mathrm{M}$, there was progressive inhibition and a rebound and offshoot was observed upon drug termination at $3 \mathrm{mM}$ with both the ligands. A T6' amino-acid in the $\beta 2$ subunit has previously been implicated in inhibitory effects of other inhibitory ligands. TM2 T6' residue of the $\beta$-subunit of glycine receptor, has been implicated in the blocking action of picrotoxin (Pribilla et al., 1992). Later it was also shown to be critical in the picrotoxin blocking action in $\mathrm{GABA}_{\mathrm{A}}$ receptor (Gurley et al., 1995) and $\rho 1 \mathrm{GABA}_{\mathrm{C}}$ receptor (Zhang et al., 1995). T6'F mutation was tested since it has been known to cause a significant reduction in picrotoxin sensitivity without abolishing it completely (Shan et al., 2001; Sedelnikova et al., 2006). We tested the hypothesis that T6' residue is implicated in the above blocking actions. TM2 T6' residue, when mutated to T6'F, both inhibition and rebound mediated by carisoprodol, was attenuated. No effect was observed on pentobarb 
mediated inhibition or rebound. Thus, pentobarbital may have different binding site or functional domain for this particular action. Pentobarbital had a direct gating effect in $\beta 3$ homomeric receptors. Both meprobamate and carisoprodol, like picrotoxin, blocked spontaneously open current in the $\beta 3$ homomer. This MEP and CSP mediated blockage was abolished in homomer with T6'F mutation, unmasking their direct gating effect. Homomer with T6'F mutation in $\beta 3$ subunit, did not affect pentobarbital mediated direct gating current, again suggesting a different binding site or a functional domain for this particular action. 


\section{Discussion}

Meprobamate was the first widely prescribed tranquilizer agent (DeLong et al., 1985). Initially found to be free of side effects in animal studies and in populations using regular therapeutic doses (Boyd et al., 1958), many cases of abuse and dependence were observed in patients having history of misuse of other drugs and alcohol abuse (Mohr et al., 1958). Also, after long term use, cases of physical and psychological dependence started to appear (Lemere, 1956; Ewing et al., 1957). Thus, it was made a controlled substance and its use started to dwindle after the introduction of benzodiazepines (Berger, 1964; Greenblatt et al., 1974). Although meprobamate was made a controlled substance, drugs metabolized to meprobamate are widely available. One such drug is the centrally acting muscle relaxant carisoprodol (Toth et al., 2004; Sullivan, 2015). It is easily available and widely used, especially after the advent of internet pharmacies. Many serious cases of abuse, dependence and withdrawal have also been reported for carisoprodol (Adams et al., 1975; Elder, 1991; Littrell et al., 1993; Rust et al., 1993; Reeves et al., 2003; Zacny et al., 2011; Zacny et al., 2012). Carisoprodol was known to act via its metabolite meprobamate, already a controlled substance and without a known mechanism of action. Our previous reports have shown carisoprodol itself, independent of meprobamate, and meprobamate act on synaptic and extra-synaptic $\mathrm{GABA}_{\mathrm{A}}$ receptor in a subunit dependent manner (Gonzalez et al., 2009b; Kumar et al., 2015). For direct-gating actions, meprobamate potency and potentially efficacy, was much higher for $\alpha 1$ expressing $\mathrm{GABA}_{\mathrm{A}}$ receptor compared to $\alpha 3$ expressing $\mathrm{GABA}_{\mathrm{A}}$ receptor. In this respect, action of meprobamate is qualitatively similar to its parent drug carisoprodol, however, the potency of this effect is lot less for meprobamate compared to carisoprodol (Gonzalez et al., 2009b; Kumar et al., 2015) (Kumar et al. 2015, in press). 
Activity of meprobamate and carisoprodol suggest a transmembrane-domain specific action (Hosie et al., 2006). Upon alignment, there is similar amino-acid compositions in the TM1-TM3 region, while TM4 region has 3 different amino-acid composition between $\alpha 1$ and $\alpha 3$ subunits. These were I419, I423 and V440 (Barnard et al., 1998; Bergmann et al., 2013). To test their role in attenuated direct gating effects of meprobamate at $\alpha 3$, we tested successive mutations from $\alpha 3$ to $\alpha 1$ subunit. An increase in direct gating efficacy was observed, suggesting the role of these amino acids for the direct-gating actions of meprobamate. A similar gain in function was also observed for carisoprodol, though of a much higher magnitude. This shows similar domains may be responsible for the direct-gating actions of carisoprodol and meprobamate.

Further, meprobamate and carisoprodol actions have been described as barbiturate like (Rho et al., 1997; Gonzalez et al., 2009b). In our previous reports, we have seen several points of similarities and differences in the actions of meprobamate, carisoprodol and barbiturates. Supra-potentiation of GABA saturation current seen in $\delta$-containing $\mathrm{GABA}_{\mathrm{A}}$ receptors was also observed with carisoprodol and meprobamate. Mice trained to identify carisoprodol also identified meprobamate and pentobarbital. Barbiturate-antagonist, bemegride, reversibly inhibited meprobamate and carisoprodol mediated currents (Gonzalez et al., 2009b)(Kumar et al., 2015, in press). Also in $\rho 1$-homomeric receptor, natively found in retina, meprobamate, carisoprodol and barbiturate pentobarbital, did not have any direct effect. However, a W328M mutation in $\rho 1$, salvaged pentobarbital mediated current, but not that of carisoprodol and meprobamate (Gonzalez et al., 2009b)(Kumar et al., 2015, in press). Also in $\beta 3$ homomeric receptors pentobarbital had a direct-gating action whereas meprobamate had an inhibitory action similar to picrotoxin. 
In this study we used $\alpha 1 \beta 2$ hetero-pentamer to test for inhibitory actions of carisoprodol, meprobamate and pentobarbital. At lower concentrations $(<100 \mu \mathrm{M})$, all three enhanced GABA mediated current. However at higher concentrations, an inhibition was observed with pentobarbital and carisoprodol. At $3 \mathrm{mM}$, a rebound current was observed upon termination of both pentobarbital and carisoprodol. Meprobamate continued to enhance GABA mediated current at concentrations tested $(3 \mathrm{mM})$. One reason could be the lower sensitivity of meprobamate compared to carisoprodol (approximately one third of carisoprodol). We may see a similar phenomenon at higher concentrations. T6' of $\beta 2$ is found in the TM2 region (pore region) and has been implicated in the inhibitory effect of picrotoxin (Pribilla et al., 1992; Gurley et al., 1995; Zhang et al., 1995). We tested whether this amino acid is responsible for the inhibitory effects observed with the two ligands as T6'F mutation has been shown to abolish picrotoxin mediated inhibition (Shan et al., 2001; Sedelnikova et al., 2006). T6', mutated to T6'F, abolished the inhibitory and rebound effects of carisoprodol but not of pentobarbital. This suggests T6' residue responsible for the inhibitory effect of carisoprodol but not of pentobarbital. At the concentrations tested, meprobamate did not show an inhibitory effect. Taken together these findings suggest a distinct sight for inhibitory actions for barbiturates compared to carisoprodol and meprobamate. 


\section{References}

Adams HR, Kerzee T, Morehead CD (1975). Carisoprodol-related death in a child. J Forensic Sci 20: 200-202.

Akaike N, Oomura Y (1985). Interactions of gamma-aminobutyric acid (GABA), pentobarbital, and homopantothenic acid (HOPA) on internally perfused frog sensory neurons. Cell Mol Neurobiol 5: 245-255.

Barnard EA, Skolnick P, Olsen RW, Mohler H, Sieghart W, Biggio G, et al. (1998). International Union of Pharmacology. XV. Subtypes of gamma-aminobutyric acidA receptors: classification on the basis of subunit structure and receptor function. Pharmacol Rev 50: 291313.

Berger FM (1964). Symposium on Anxiety and a Decade of Tranquilizer Therapy. The Tranquilizer Decade. J Neuropsychiatr 5: 403-410.

Bergmann R, Kongsbak K, Sorensen PL, Sander T, Balle T (2013). A unified model of the $\mathrm{GABA}(\mathrm{A})$ receptor comprising agonist and benzodiazepine binding sites. PLoS One 8: e52323.

Bormann J (2000). The 'ABC' of GABA receptors. Trends Pharmacol Sci 21: 16-19.

Boyd LJ, Cammer L, Mulinos MG, Huppert VF, Hammer H (1958). Meprobamate addiction. J Am Med Assoc 168: 1839-1843.

Chen CH, Huang CC, Liao DL (2014). Association analysis of GABRB3 promoter variants with heroin dependence. PLoS One 9: e102227.

Cockcroft V, Ortells M, Lunt G (1995). Ligands, receptor models, and evolution. Ann N Y Acad Sci 757: 40-47.

DeLong RE, Phillis JW, Barraco RA (1985). A possible role of endogenous adenosine in the sedative action of meprobamate. Eur J Pharmacol 118: 359-362.

Elder NC (1991). Abuse of skeletal muscle relaxants. Am Fam Physician 44: 1223-1226.

Ewing JA, Fullilove RE (1957). Addiction to meprobamate. N Engl J Med 257: 76-77. 
Gonzalez LA, Gatch MB, Taylor CM, Bell-Horner CL, Forster MJ, Dillon GH (2009). Carisoprodol-mediated modulation of GABAA receptors: in vitro and in vivo studies. $J$ Pharmacol Exp Ther 329: 827-837.

Greenblatt DJ, Shader RI (1974). Drug therapy. Benzodiazepines (second of two parts). N Engl J Med 291: 1239-1243.

Gurley D, Amin J, Ross PC, Weiss DS, White G (1995). Point mutations in the M2 region of the alpha, beta, or gamma subunit of the GABAA channel that abolish block by picrotoxin. Receptors Channels 3: 13-20.

Hendley CD, Lynes TE, Berger FM (1954). Effect of 2-methyl, 2-n-propyl-1,3-propanediol dicarbamate (Miltown) on central nervous system. Proc Soc Exp Biol Med 87: 608-610.

Hosie AM, Wilkins ME, da Silva HM, Smart TG (2006). Endogenous neurosteroids regulate GABAA receptors through two discrete transmembrane sites. Nature 444: 486-489.

Kumar M, Gonzalez LA, Dillon GH (2015). Assessment of subunit-dependent direct gating and allosteric modulatory effects of carisoprodol at GABAA receptors. Neuropharmacology 97: 414-425.

Lemere F (1956). Habit-forming properties of meprobamate. AMA Arch Neurol Psychiatry 76: 205-206.

Littrell RA, Hayes LR, Stillner V (1993). Carisoprodol (Soma): a new and cautious perspective on an old agent. South Med J 86: 753-756.

Miyazawa A, Fujiyoshi Y, Unwin N (2003). Structure and gating mechanism of the acetylcholine receptor pore. Nature 423: 949-955.

Mohr RC, Mead BT (1958). Meprobamate addiction. N Engl J Med 259: 865-868.

Olsen H, Koppang E, Alvan G, Morland J (1994). Carisoprodol elimination in humans. Ther Drug Monit 16: 337-340.

Orser BA, Wang LY, Pennefather PS, MacDonald JF (1994). Propofol modulates activation and desensitization of GABAA receptors in cultured murine hippocampal neurons. $J$ Neurosci 14: 7747-7760. 
Pribilla I, Takagi T, Langosch D, Bormann J, Betz H (1992). The atypical M2 segment of the beta subunit confers picrotoxinin resistance to inhibitory glycine receptor channels. EMBO J 11: 4305-4311.

Reeves RR, Parker JD (2003). Somatic dysfunction during carisoprodol cessation: evidence for a carisoprodol withdrawal syndrome. J Am Osteopath Assoc 103: 75-80.

Rho JM, Donevan SD, Rogawski MA (1997). Barbiturate-like actions of the propanediol dicarbamates felbamate and meprobamate. J Pharmacol Exp Ther 280: 1383-1391.

Rust GS, Hatch R, Gums JG (1993). Carisoprodol as a drug of abuse. Arch Fam Med 2: 429432.

Sedelnikova A, Erkkila BE, Harris H, Zakharkin SO, Weiss DS (2006). Stoichiometry of a pore mutation that abolishes picrotoxin-mediated antagonism of the GABAA receptor. $J$ Physiol 577: 569-577.

Shan Q, Haddrill JL, Lynch JW (2001). Ivermectin, an unconventional agonist of the glycine receptor chloride channel. J Biol Chem 276: 12556-12564.

Sigel E, Buhr A (1997). The benzodiazepine binding site of GABAA receptors. Trends Pharmacol Sci 18: 425-429.

Sine SM, Engel AG (2006). Recent advances in Cys-loop receptor structure and function. Nature 440: 448-455.

Sullivan MD (2015). What are we treating with opioid and sedative-hypnotic combination therapy? Pharmacoepidemiol Drug Saf 24: 893-895.

Toth PP, Urtis J (2004). Commonly used muscle relaxant therapies for acute low back pain: a review of carisoprodol, cyclobenzaprine hydrochloride, and metaxalone. Clin Ther 26: 13551367.

Xu M, Akabas MH (1996). Identification of channel-lining residues in the M2 membranespanning segment of the GABA(A) receptor alpha1 subunit. J Gen Physiol 107: 195-205.

Zacny JP, Paice JA, Coalson DW (2011). Characterizing the subjective and psychomotor effects of carisoprodol in healthy volunteers. Pharmacol Biochem Behav 100: 138-143. 
Zacny JP, Paice JA, Coalson DW (2012). Subjective and psychomotor effects of carisoprodol in combination with oxycodone in healthy volunteers. Drug Alcohol Depend 120: 229-232.

Zhang D, Pan ZH, Zhang X, Brideau AD, Lipton SA (1995). Cloning of a gammaaminobutyric acid type $\mathrm{C}$ receptor subunit in rat retina with a methionine residue critical for picrotoxinin channel block. Proc Natl Acad Sci U S A 92: 11756-11760. 
Table III-1. Influence of GABAA receptor $\alpha 3$ TM4 amino acids mutation to corresponding $\alpha 1$ amino acids on GABA EC50 values Each data point represents the mean \pm S.E.M of $\mathrm{n}$ cells. ${ }^{*}, \mathrm{p}<0.05 ; * *, \mathrm{p}<0.01$ relative to wild type $\alpha 3 \beta 2 \gamma 2$ GABAA receptors. 


\begin{tabular}{|c|c|c|c|c|}
\hline $\begin{array}{c}\text { Receptor } \\
\text { Configuration }\end{array}$ & $\begin{array}{l}\text { GABA } \\
\text { EC }_{50}(\mu \mathrm{M})\end{array}$ & $\mathbf{n}$ & $\begin{array}{l}\text { MEP gating } \\
(\% \text { of GABA } \\
\text { max) }\end{array}$ & $\mathbf{n}$ \\
\hline$\alpha 3 \mathrm{WT}$ & $34.8 \pm 2.1$ & 6 & $7.25 \pm 2.8$ & 5 \\
\hline$\alpha 3(\mathrm{~V} 440 \mathrm{~L})$ & $07.5 \pm 0.9 * *$ & 7 & $13.25 \pm 1.89$ & 3 \\
\hline$\alpha 3(1419 L / 1423 A)$ & $18.1 \pm 2.2^{*}$ & 9 & $12 \pm 4$ & 3 \\
\hline$\alpha 3(1419 L / 1423 A / V 440 L)$ & $15.8 \pm 5.0 *$ & 6 & $8 \pm 2.65$ & 3 \\
\hline$\alpha 1 \mathrm{WT}$ & $28.6 \pm 2.75$ & 8 & $32 \pm 8.1$ & 5 \\
\hline
\end{tabular}


Figure 1. Alignment of $\alpha 1$ and $\alpha 3$ domains of TM4 showing non-identical (red) and mutated (*) amino acids. Conserved (black). 


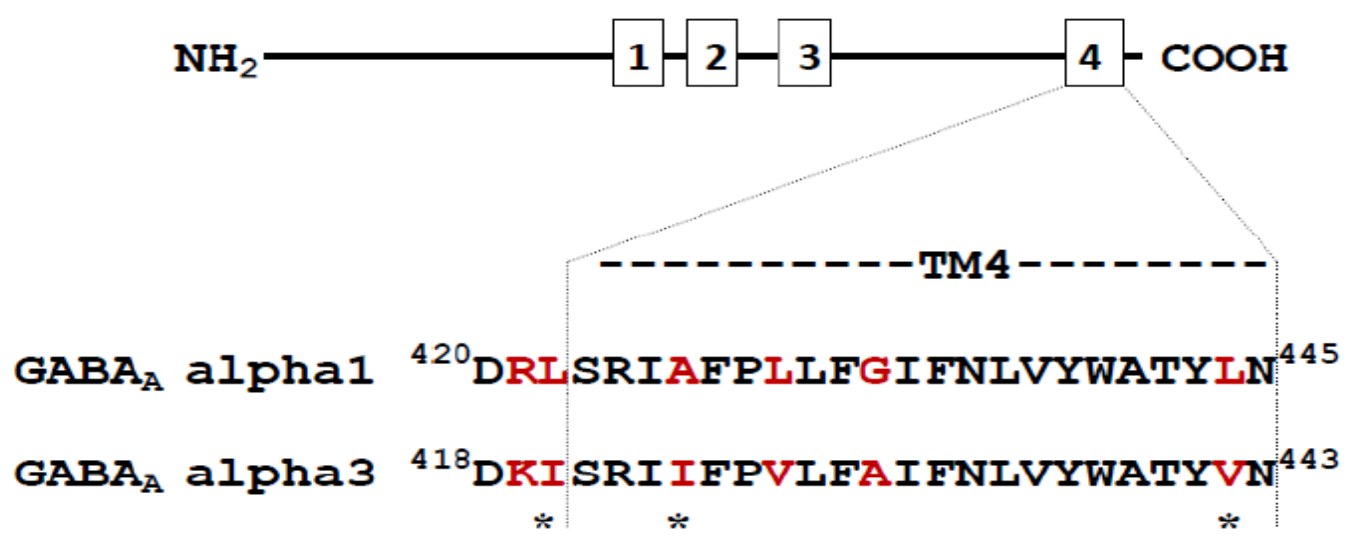


Figure 2. Influence of the alpha3 subunit TM4 mutations on direct activation by meprobamate. A, representative traces demonstrating carisoprodol and meprobamate activate human $\alpha 3$ (V441L) $\beta 2 \gamma 2$ GABA $_{A}$ Rs. B, bar graphs summarizing meprobamate direct gating currents for human $\alpha 3-, \alpha 3$ (V441L)-, $\alpha 3$ (I420L/I424A/V441L) and $\alpha 1 \beta 2 \gamma 2$ GABA $_{\mathrm{A}}$ Rs. **, $p<0.01, *, p<0.05 . \quad$ MT1 - $\alpha 3(\mathrm{~V} 441 \mathrm{~L}) ;$ MT2 - $\alpha 3(\mathrm{I} 420 \mathrm{~L} / \mathrm{I} 424 \mathrm{~A})$ and MT3 - $\alpha 3$ (I420L/I424A/ V441L). 
A

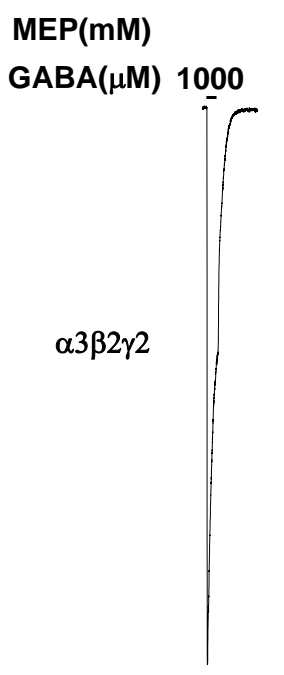

$3 \quad 10$

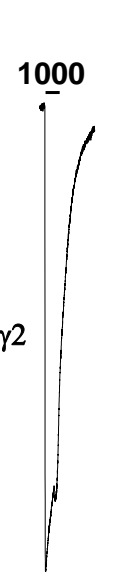

310

$3 \quad 10$

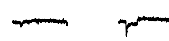<smiles>CCC</smiles>

$\alpha 3(\mathrm{MT} 1) \beta 2 \gamma 2$

300pA L $10 \mathrm{~s}$

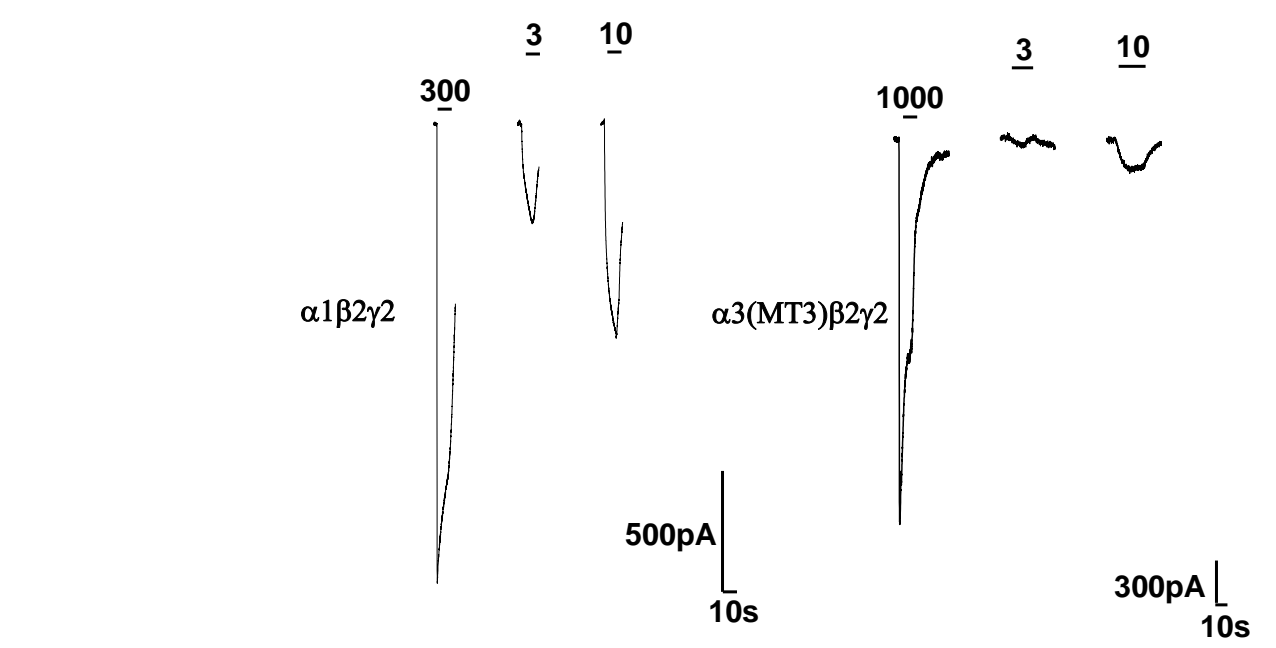

$3 \quad 10$
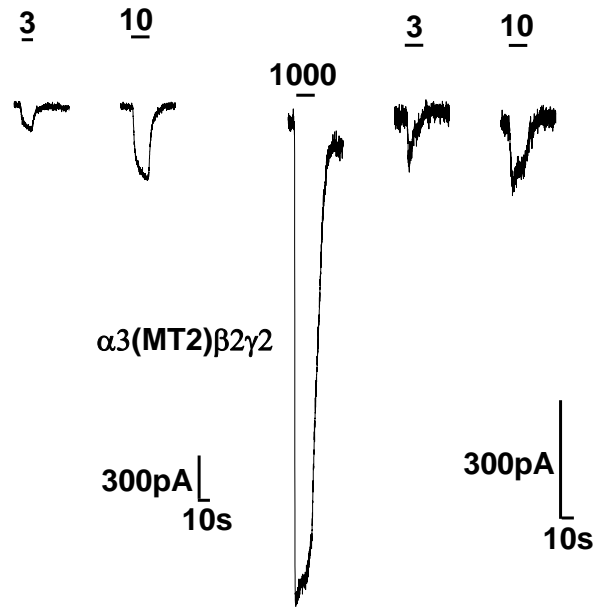

B

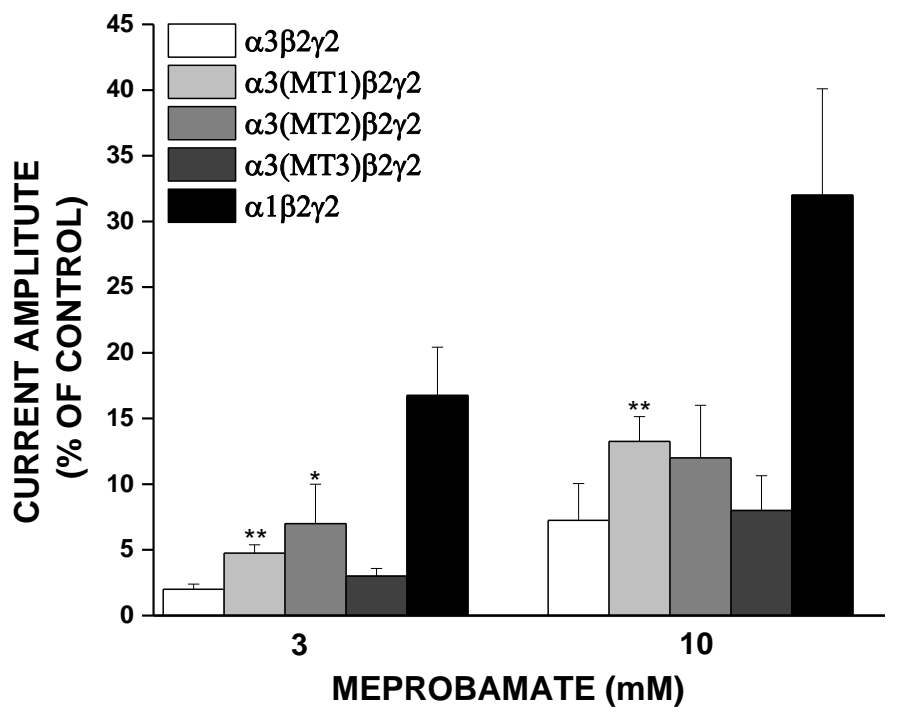


Figure 3. Influence of $\beta$-subunit TM2 T6'F Mutation on inhibitory effects of carisoprodol. A) Representative traces from R- $\alpha 1 \beta 2$ GABAA receptor demonstrating modulation of GABAgated currents by carisoprodol. At high concentrations, currents are inhibited and offshoot currents are observed upon termination of drug application. This phenomenon is attenuated with $\alpha 1 \beta 2$ (T6'F) GABAA receptor. B) Low concentration CSP potentiated the GABA gated current of both R- $\alpha 1 \beta 2$ GABAA receptor and R- $\alpha 1 \beta 2$ (T6'F) GABAA receptor. High concentration of CSP inhibit R- $\alpha 1 \beta 2$ receptors but in R- $\alpha 1 \beta 2$ (T6'F) receptors, inhibitory effect was attenuated. Each bar represents the mean \pm S.E. of the 7-9 cells. 


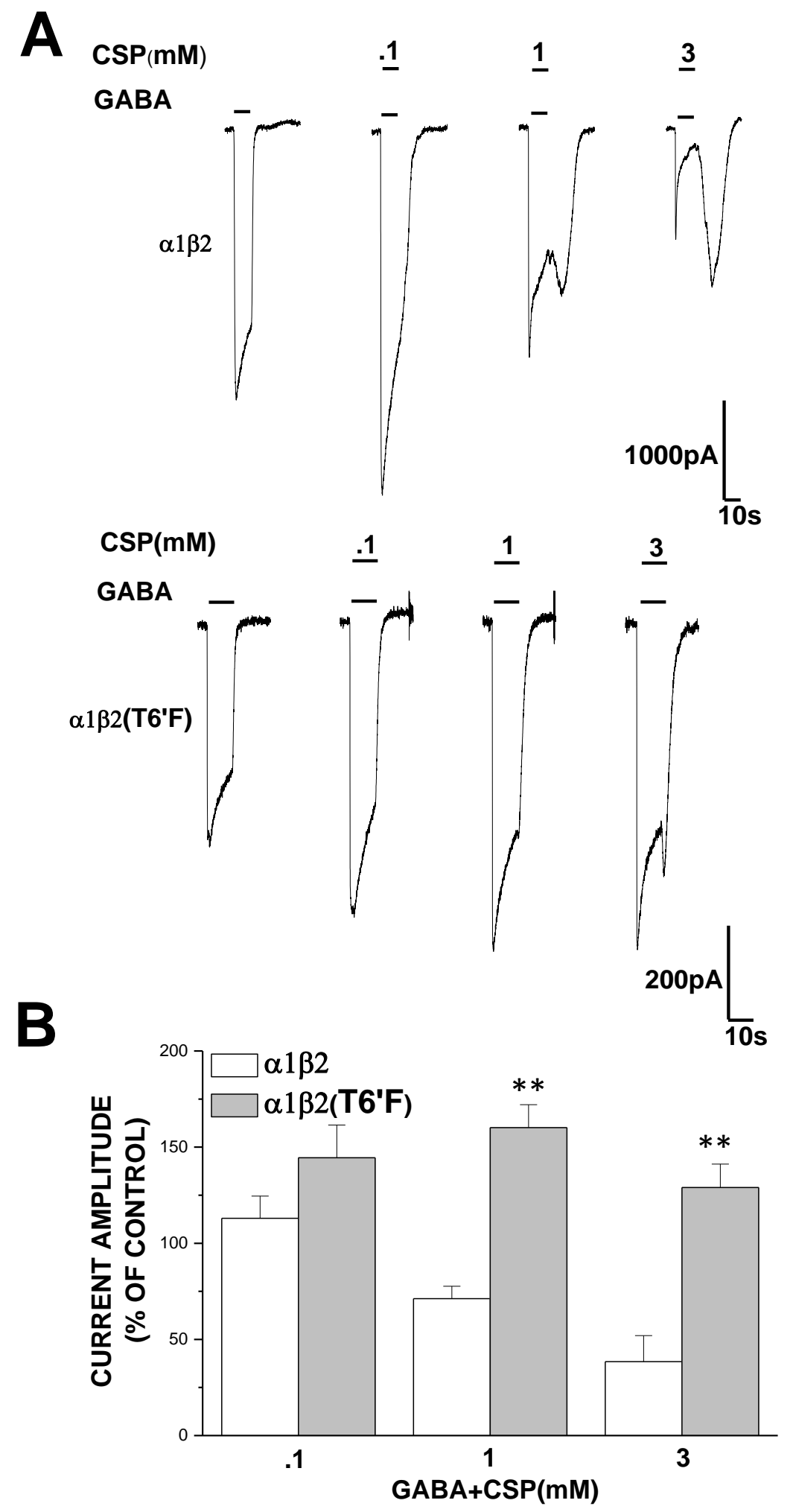


Figure 4. Influence of $\beta$-subunit TM2 T6'F Mutation on inhibitory effect by pentobarbitol. A) Representative traces from R- $\alpha 1 \beta 2$ GABAA receptor demonstrating modulation of GABA-gated currents by pentobarbital. At high concentrations, currents are inhibited and offshoot currents are observed upon termination of drug application. A similar phenomenon is observed with $\alpha 1 \beta 2$ (T6'F) GABAA receptor. B) Low concentration PB potentiated the GABA gated current of both R- $\alpha 1 \beta 2$ GABAA receptor and R- $\alpha 1 \beta 2$ (T6'F) GABAA receptor. High concentration of PB inhibit R- $\alpha 1 \beta 2$ receptors but in R- $\alpha 1 \beta 2$ (T6'F) receptors, inhibitory effect was not attenuated unlike CSP. Each bar represents the mean \pm S.E. of the 7-8 cells. 
A
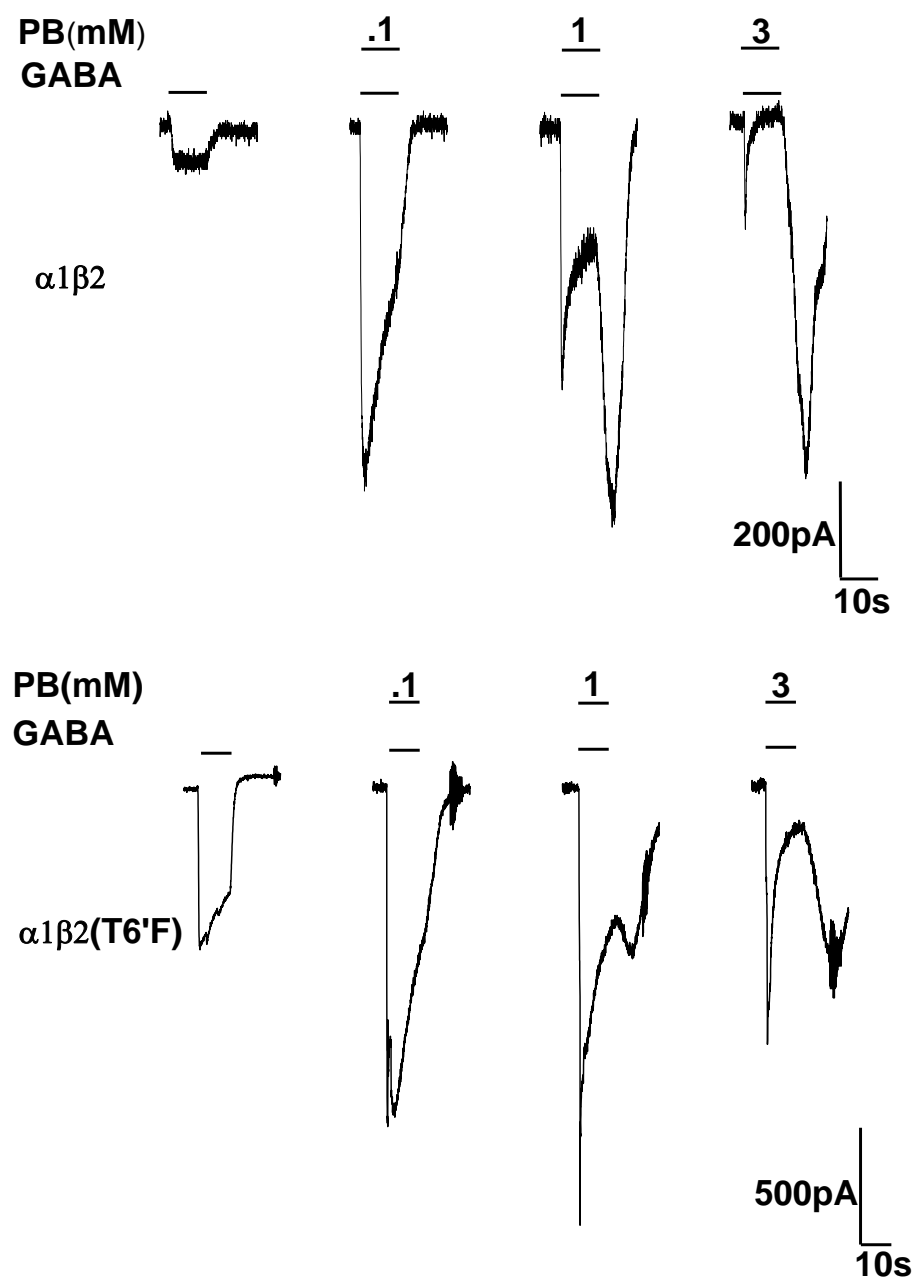

B

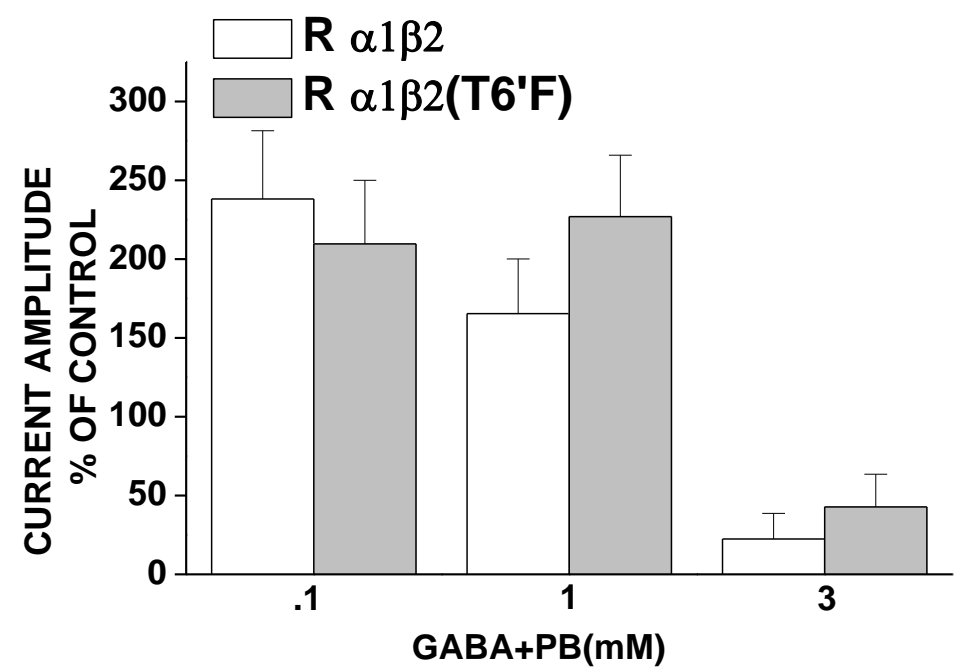


Figure 5. Influence of $\beta$-subunit TM2 T6'F Mutation on allosteric modulation by MEP. A) Representative traces from R- $\alpha 1 \beta 2$ GABAA receptor demonstrating modulation of GABAgated currents by MEP. At high concentrations, no offshoot currents are observed upon termination of drug application and currents are not inhibited as seen with CSP or PB. A similar phenomenon is observed with $\alpha 1 \beta 2$ (T6'F) GABAA receptor. B) Low concentration MEP potentiated the GABA gated current of both R- $\alpha 1 \beta 2$ GABAA receptor and R- $\alpha 1 \beta 2$ (T6'F) GABAA receptor. High concentrations of MEP do not inhibit R- $\alpha 1 \beta 2$ or R- $\alpha 1 \beta 2$ (T6'F) receptors. Each bar represents the mean \pm S.E. of the 7-8 cells. 

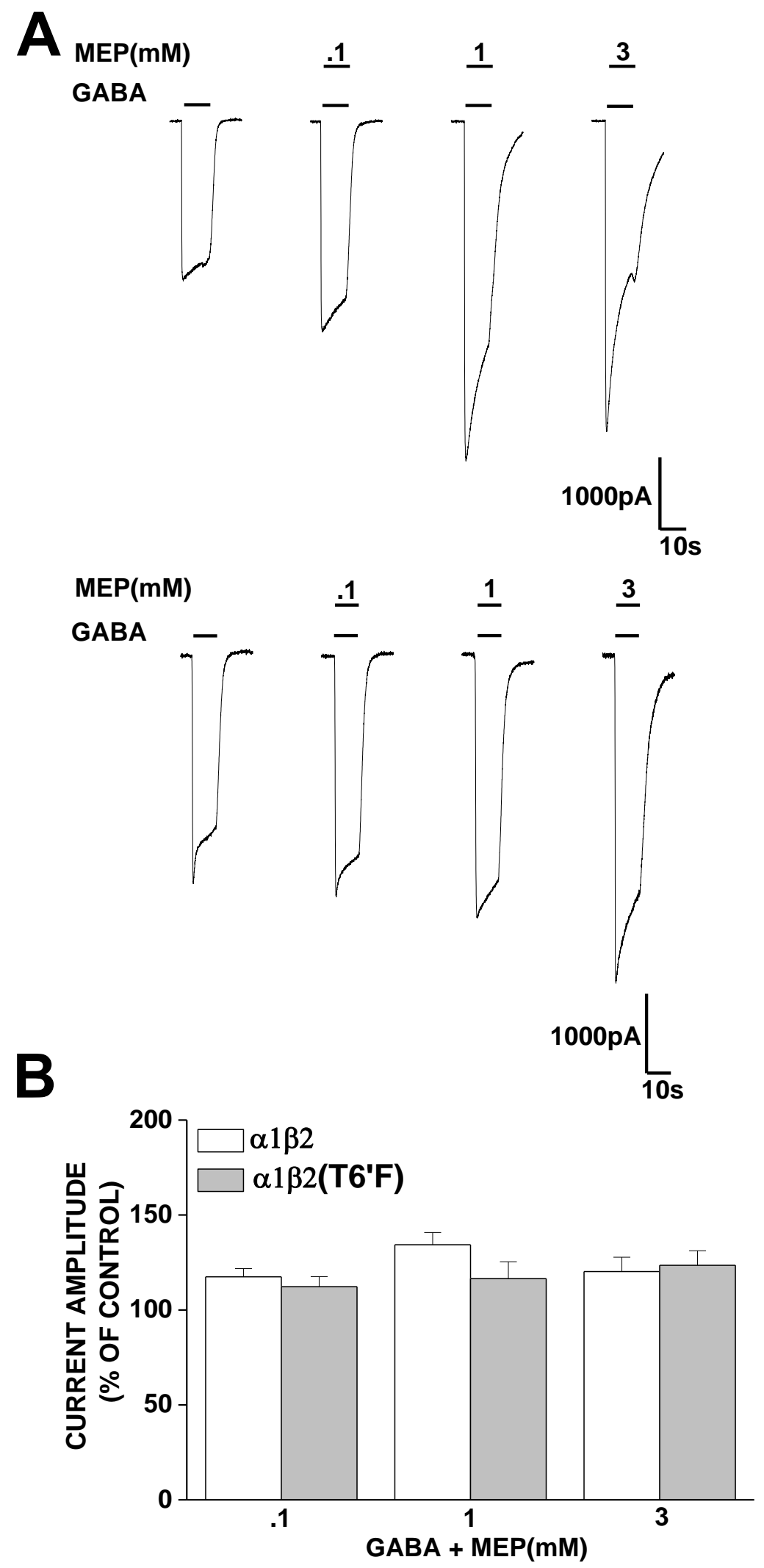


\section{CHAPTER IV}




\section{SUMMARY, DISCUSSION AND FUTURE DIRECTIONS}

Meprobamate was the first drug to be prescribed purely as a tranquillizer, that is, capable of allaying anxiety without inducing sedation or sleep (DeLong et al., 1985). It was a wonder drug when introduced and sold billions of pills. With therapeutic doses, it did not produce addiction or dependence, even after prolonged use (Boyd et al., 1958). Higher than normal dose, in patients with history of other drugs or alcohol abuse, led to all the characteristics of a habit forming drug. These include an intense craving for the drug based on its euphoric effect, tolerance build up, requiring increasingly larger doses to produce the same effect, and withdrawal symptoms associated with sudden discontinuation of the drug (Lemere, 1956; Mohr et al., 1958). Considering increasing number of cases of physical and psychological dependence, meprobamate was made a controlled substance (Greenblatt et al., 1971; Hollister, 1983). While meprobamate is a controlled substance, drugs metabolized to meprobamate are widely and easily available, and abused. One such drug, carisoprodol, is a widely prescribed centrally acting skeletal muscle relaxant (Toth et al., 2004; Sullivan, 2015). It is most commonly used for short term allaying of skeletal muscle pain and discomfort. Carisoprodol use has been characterized by quick development of tolerance, leading to use of increasing doses to produce the desired effect. After long term use of high dose of carisoprodol, strong withdrawal symptoms have been observed. These include delusion, seizure and even death (Adams et al., 1975; Elder, 1991; Littrell et al., 1993; Rust et al., 1993; Reeves et al., 2003; Zacny et al., 2011; Zacny et al., 2012). Considering the dangers posed by the abuse of carisoprodol, it was made a scheduled 4 controlled substance at the federal level in January 2012 by the United States Drug Enforcement Administration. Considering present and potential danger posed by carisoprodol use and abuse, it was of utmost importance to know its detailed mechanism of action. For long it was known to act via its metabolite meprobamate, 
which lacks the isopropyl group found in carisoprodol. Meprobamate is already a controlled substance, but its detailed mechanism of action is also unknown.

It has been shown that the therapeutic and adverse effects of GABA ligands depend upon their interactions with the $\mathrm{GABA}_{\mathrm{A}}$ receptor subunits (Ito et al., 1996; Ator, 2005; Licata et al., 2005; Wafford, 2005; Olsen et al., 2008). $\alpha 2$ containing $\mathrm{GABA}_{\mathrm{A}}$ receptors have the anxiolytic and, to a large extent, myorelaxant actions; and the $\alpha 3$ - and $\alpha 5$-containing $\mathrm{GABA}_{\mathrm{A}}$ receptors, have the myorelaxant actions. Moreover, tolerance to the sedative action has been linked to $\alpha 5$-containing $\mathrm{GABA}_{\mathrm{A}}$ receptors, and their addictive properties to $\alpha 1$-containing GABA $_{\mathrm{A}}$ receptors (Low et al., 2000; McKernan et al., 2000; Crestani et al., 2001; Crestani et al., 2002; Rudolph et al., 2004; van Rijnsoever et al., 2004; Tan et al., 2010). In addition, physical dependence is more likely to develop with drugs that interact with a broader collection of $\mathrm{GABA}_{\mathrm{A}}$ receptor subtypes and misuse of agents that directly gate the receptor is more likely to result in fatal complications than those that only allosterically enhance receptor activity (Licata et al., 2008; Fass, 2010). So we tested for detailed subunit dependent action of carisoprodol on $\mathrm{GABA}_{\mathrm{A}}$ receptor, but in order to understand a complete pharmacological profile of this widely used and abused drug, we also set out to understand the complete subunit dependent action of its metabolite, meprobamate. The only knowledge regarding the action of meprobamate was its interaction in a barbiturate like manner with $\mathrm{GABA}_{\mathrm{A}}$ receptors. So, we also set out to chalk out the difference between the action of meprobamate and barbiturate pentobarbital.

We found meprobamate to have direct gating, allosteric modulatory and inhibitory actions on various synaptic and extra-synaptic $\mathrm{GABA}_{\mathrm{A}}$ receptors. For direct gating, $\alpha 1$ had significantly more efficacy than $\alpha 3$ containing receptors. To understand the molecular basis for the difference, amino-acid compositions of the $\alpha 3$ and $\alpha 1$-subunits were aligned. We identified 
several amino-acids of difference between the two subunits in the TM4 region. Using site directed mutagenesis, amino-acids from $\alpha 3$ were converted to those in $\alpha 1$ either singly or in combination. We found a gain in function, suggesting these amino-acids to be responsible for attenuated $\alpha 3$ direct gating action. A similar gain in function was also observed for carisoprodol, however of a much higher magnitude. Structural difference between carisoprodol and meprobamate is minimal. Both are propanediol bicarbamate, with carisoprodol having an isopropyl group, absent in meprobamate.

For allosteric modulatory action of meprobamate, $\alpha 5$ subunit was somewhat more efficaceous compared to other subunits. In carisoprodol, $\alpha 1$ subunit was significantly more potent and efficacious than other subunits. Also, carisoprodol potency on all the subunits, was more than meprobamate. So for allosteric-modulatory actions, a difference in potency and subunit preferring effect was observed.

Effects of $\beta$ and $\gamma$ subunits were also tested for direct gating and allosteric modulatory effects. $\gamma$ subunit did not have any influence on both these effects of carisoprodol. While for meprobamate, $\gamma$ subunit did not influence the direct gating but had a significant inhibitory effect for allosteric-modulation. $\beta$ subunit had an effect on both the direct gating and allosteric modulation of carisoprodol. $\beta 1$ subunit had significantly more direct-gating effect compared to $\beta 2$ while $\beta 2$ had significantly more allosteric-modulatory effect compared to $\beta 1$. $\beta$-subunit did not influence either meprobamate direct gating or allosteric modulation. The above differences may be exploited to know about the critical domains responsible for the action of meprobamate and carisoprodol.

Extra-synaptic $\mathrm{GABA}_{\mathrm{A}}$ receptors represented by $\alpha 4 \beta 3 \delta$ and $\alpha 1 \beta 3 \delta$ were also tested. Both meprobamate and carisoprodol had a supra-potentiation effect on GABA saturation. In 
this respect, actions of both carisoprodol and meprobamate were barbiturate like. For direct gating action on the extra-synaptic receptors, both carisoprodol and meprobamate were almost as much efficacious as GABA. Both meprobamate and carisoprodol also had allostericmodulatory effects on the extra-synaptic receptors.

Further comparison with the barbiturates was done using $\rho 1$ homomeric receptors found natively in retinal ganglion cells and $\beta 3$ homomeric receptors, not found natively. All three, meprobamate, carisoprodol and pentobarbital did not have a direct gating action on $\rho 1$ homomeric receptors. A mutation W328M, however, salvaged the direct gating action of pentobarbital, but not of carisoprodol or meprobamate. For $\beta 3$-homomeric $\mathrm{GABA}_{\mathrm{A}}$ receptors, barbiturate pentobarbital had an agonist effect while meprobamate, blocked the spontaneously open current, a mechanism followed by picrotoxin, a known GABA inhibitor. A T6'F mutation in $\beta 3$ subunit abolished the meprobamate mediated inhibition, without affecting the pentobarbital mediated direct gating.

In receptors formed by $\alpha 1 \beta 2$, allosteric actions of meprobamate, carisoprodol and pentobarbital were tested. Meprobamate, at tested concentrations (maximum $3 \mathrm{mM}$ ), continuously potentiated GABA mediated current in a concentration dependent manner. At lower concentrations $(<100 \mu \mathrm{M})$, carisoprodol and pentobarbital potentiated GABA gated currents in a concentration dependent manner but at higher doses, showed an inhibition and a rebound at 3mM. T6' residue in $\beta$-subunit TM2 region (pore forming region) when mutated to T6'F, attenuates the inhibition and abolishes the rebound in carisoprodol, but not pentobarbital. Thus 6' residue seems to be involved in the inhibitory actions of carisoprodol, but not pentobarbital. At concentrations tested, meprobamate did not show an inhibitory action in $\alpha 1 \beta 2$ receptors. Meprobamate may show an inhibitory and rebound effect on testing at higher concentration as it has shown to be approximately 3 times less sensitive than carisoprodol, in 
our previous reports. In $\beta 3$ homomeric receptor both meprobamate and carisoprodol block spontaneously open current. A T6'F mutation abolishes this action for both carisoprodol and meprobamate and unmask their direct gating effect. So the $\beta 3$ actions represent a similarity of action of meprobamate and carisoprodol, representing a similar binding site/or functional domain for this particular action, between carisoprodol and meprobamate. Pentobarb has an agonist action at $\beta 3$ homomeric receptors representing a different binding site/functional domain than both meprobamate and carisoprodol.

In an effort towards drug development, we need to further explore the mechanism of actions of meprobamate. We saw a gain in function for the direct action from $\alpha 3$ to $\alpha 1$ conversion mutations in the TM4 region. We need to test the same for the reverse mutations from $\alpha 1$ to $\alpha 3$ and observe whether there is a loss of function. A similar study conducted for carisoprodol, showed leucine residue at position 415 of $\alpha 1$ subunit to be responsible for its direct gating action. The combination of the above two studies would help us to identify the amino acids responsible for the direct gating actions of the meprobamate.

An important study would be to identify the property of the amino-acids responsible for the direct gating action. For this, amino-acid identified for the direct gating action shall be mutated to various other amino acids with varying size, charge, hydrophoebicity or polarity. A correlation observed between the magnitude of the current and a particular property would help us identify that particular property to be responsible for the direct gating. For carisoprodol, at position 415 , volume and polarity of the amino acids have been shown to be associated with its direct gating efficacy. A similar study shall be undertaken to find the binding domain and property of the amino acids responsible for the allosteric modulation. Above amino acids did not seem to have an effect on the allosteric modulatory effect of carisoprodol. For further 
understanding of the domains responsible for the binding pocket for direct gating and allosteric modulatory action, we shall also take resort to molecular modeling techniques.

Further, allosteric modulatory actions of general anesthetics etomidate, propofol and isoflurane have shown voltage dependence (O'Toole et al., 2012). Parent drug of meprobamate, carisoprodol has also shown voltage dependent allosteric modulatory actions but not direct gating action (Kumar et al., 2015). Again showing a different binding sites for carisoprodol for direct gating and allosteric modulatory effects and thus multiple binding sites for carisoprodol at $\mathrm{GABA}_{\mathrm{A}}$ receptor. It would be interesting to see whether meprobamate mediated actions also show voltage dependence.

We are still not sure whether the amino acid identified via the mutation studies participate in the direct binding or carry the wave of conformational changes, a mechanism called coupling. Substituted cysteine accessibility method would help us to differentiate between the two. The substituted-cysteine accessibility method (SCAM) provides an approach for identifying the amino acid residues that line channels, transporters, or binding-site crevices in membrane-spanning proteins (Chen et al., 1997; Javitch et al., 1998; Dodd et al., 2005). SCAM can also be used to investigate structural alterations in membrane-spanning segments in different functional states of proteins. Sulfhydryl group of native or engineered cysteine of a protein can be at water accessible surface, lipid accessible surface or a protein interior. Rate of reaction of a hydrophilic reagent would be much faster with an ionized sulfhydryl group (at water accessible region) than a non ionized sulfhydryl group. Measuring the rate of change of reaction of an engineered cysteine with a hydrophilic reagent in presence or absence of a ligand can help us conclude the movement of the particular amino acid (and thus the loop) in presence of the ligand and thus its participation in the gating process of a ligand. 
It has become increasingly clear in recent years that many therapeutic and adverse actions of GABAergic drugs associate predominantly with particular subunits of the $\mathrm{GABA}_{\mathrm{A}}$ receptor. This has been studied extensively in animal models in which a particular subunit is deleted and resultant absence of a particular effect is attributed to the deleted subunit. This technique has been used to show the subunits responsible for alcohol tolerance, dependence, consumption and taste aversion (Barnard et al., 1998; Jacob et al., 2008; Miller et al., 2014; Whissell et al., 2015). A role for extrasynaptic receptors have also been attributed for alcohol consumption using similar techniques (Feusner et al., 2001). Knockout mice have also been used for assessing therapeutic and abuse potentials for benzodiazepines (Rudolph et al., 2011). Our study demonstrates that meprobamate action in-vitro depends upon $\mathrm{GABA}_{\mathrm{A}}$ receptor subtype isoforms. A further testing of our findings in in-vivo model in the knockout mice would further confirm actions of meprobamate on the tested subunits and help us better predict subunit dependent effects of meprobamate.

Meprobamate has both tranquilizing and muscle relaxing properties. An initial effort was made by Berger for preparation of compounds for the separation of the above two activities. In this effort many compounds chemically related to meprobamate were prepared and subjected to pharmacological evaluation (Berger et al., 1960). From the chemical formula of meprobamate, 2-methyl-2-propyl-1, 3-propanediol dicarbamate, the $\mathrm{N}$-substituted and $\mathrm{N}$ nonsubstituted compounds were tested for muscle relaxant, anti-convulsant and toxic actions. $\mathrm{N}$-isopropyl-2-methyl-2-propyl-1, 3-propanediol dicarbamate, or carisoprodol showed a promising muscle relaxant action alienated from tranquilizing action of meprobamate (Berger et al., 1960). Carisoprodol was further tested and made available for medical use. One reason CSP was further evaluated was its proximity to the structure of meprobamate which was widely used at that time and thus had a proven safety profile. Also with the cost of further evaluation, 
not many compounds could have been tested at that time. However many compounds generated showed a promising muscle relaxant and anti-convulsant profile. Chemical groups commonly tested were 3-propanediols; 1, 3-propanediol bicarbamates and 3-hydroxypropyl carbamates (Figure 1) (Ludwig et al., 1969).

Compounds of interest were 2-substituted 1, 3-propanediol bicarbamates. A total of 5-7 carbon atoms at the 2-position had the greatest muscle relaxing properties. An aryl group reduces muscle relaxing properties, while a methyl and a phenyl group has an enhanced anticonvulsant activity and reduced muscle relaxing properties. N-Substituted compounds have also shown interesting properties. Replacement of one of N-hydrogen of the carbamate has yielded a number of compounds with interesting muscle relaxing properties. A prominent example is widely prescribed muscle relaxant carisoprodol or $\mathrm{N}$-isopropyl-2-methyl-2-propyl1, 3-propanediol dicarbamate (Ludwig et al., 1969).

2-Substituted and $\mathrm{N}$-substituted 3-hydroxypropyl carbamate, also show prominent muscle relaxing and anti-convulsant properties. 4-5 alkyl groups at position 2 gave good muscle relaxing property while an aromatic group at this position had good anti-convulsant property and attenuated muscle relaxant property. N-Substituted compounds also had prominent muscle relaxant and anti-convulsant compounds (Ludwig et al., 1969).

Our lab provides low cost methods for further evaluation of these drugs. A testing at $\mathrm{GABA}_{\mathrm{A}}$ subunits would enable us to have a quick prediction of therapeutic and abuse potentials of these drugs. We would start by generation of as many of the above promising ligands as possible. Each of the ligand would be tested for direct gating and allosteric modulatory effects at various $\alpha$ and $\beta$ subunit combinations of the $\mathrm{GABA}_{\mathrm{A}}$ receptors. Thus a pharmacologic profile 
of each ligand would be generated, along with a note on possible therapeutic as well as abuse potentials of each ligand. Promising ligands would be further tested in animal models. 
Figure 1: Chemical structure of meprobamate; 1,3 propanediol; 3-hydroxypropyl carbamate 
<smiles>CCCC(C)(COC(N)=O)COC(N)=O</smiles>

Meprobamate<smiles>OCCCO</smiles>

\section{1,3-propanediol}<smiles>NC(=O)OCCCO</smiles>

3-hydroxypropyl carbamate 
In between carisoprodol and meprobamate, they have global effect on various subunit combinations of synaptic and extra-synaptic $\mathrm{GABA}_{\mathrm{A}}$ receptors. In addition to having effects on GABA mediated currents, they also have a direct-gating actions on all these native receptors. Meprobamate have also been shown to have partial inhibitory effect on NMDA receptors (Rho et al., 1997). In our lab and our colleague's, we have shown carisoprodol also to have partial inhibitory effect on NMDA receptors, both in vitro in HEK-t transfected cells, as well as in animals trained to identify carisoprodol. Further clinical effects of carisoprodol also seem to affect serotonergic receptors (Bramness et al., 2005). Both the actions of carisoprodol and meprobamate on NMDA and 5 HT-3 receptors need to be further explored. Our knowledge of qualitative and quantitative aspects of effects of meprobamate and carisoprodol on various subunits of synaptic and extra-synaptic $\mathrm{GABA}_{\mathrm{A}}$ receptors, have enabled us to explain molecular basis of various clinical and toxic effects observed with the use and abuse of these drugs. Further research on the molecular mechanism of actions of these drugs (further exploration on $\mathrm{GABA}_{\mathrm{A}}$ receptors, NMDA and 5HT-3 receptors), would not only explain the clinical effects observed, but may also enable us to bring these drugs for new uses in select group of patients with specific needs. Our studies in lab could also prove to be important for drug development, as molecules with induced structural changes to have desired properties, can be quickly tested in cellular models, rather than time taking and costly animal models used in the initial development of these drugs. MEP and CSP would prove to be important drugs for blanket testing of reagents for a particularly useful action at an unknown potential therapeutic site of action or interaction with useful enzymes. Like amantadine, an anti-influenza drug also used as an anti-parkinsonism drug, their global action on receptors with varying physiological actions may prove to be an important property to test for actions on unknown useful sites. 


\section{References:}

Adams HR, Kerzee T, Morehead CD (1975). Carisoprodol-related death in a child. J Forensic Sci 20: 200-202.

Akaike N, Oomura Y (1985). Interactions of gamma-aminobutyric acid (GABA), pentobarbital, and homopantothenic acid (HOPA) on internally perfused frog sensory neurons. Cell Mol Neurobiol 5: 245-255.

Allen MD, Greenblatt DJ, Noel BJ (1977). Meprobamate overdosage: a continuing problem. Clin Toxicol 11: 501-515.

Amin J (1999). A single hydrophobic residue confers barbiturate sensitivity to gammaaminobutyric acid type C receptor. Mol Pharmacol 55: 411-423.

Amin J, Weiss DS (1994). Homomeric rho 1 GABA channels: activation properties and domains. Receptors Channels 2: 227-236.

Ator NA (2005). Contributions of GABAA receptor subtype selectivity to abuse liability and dependence potential of pharmacological treatments for anxiety and sleep disorders. CNS Spectr 10: 31-39.

Barnard EA, Skolnick P, Olsen RW, Mohler H, Sieghart W, Biggio G, et al. (1998). International Union of Pharmacology. XV. Subtypes of gamma-aminobutyric acidA receptors: classification on the basis of subunit structure and receptor function. Pharmacol Rev 50: 291-313.

Baumann SW, Baur R, Sigel E (2001). Subunit arrangement of gamma-aminobutyric acid type A receptors. J Biol Chem 276: 36275-36280.

Baumann SW, Baur R, Sigel E (2003). Individual properties of the two functional agonist sites in GABA(A) receptors. J Neurosci 23: 11158-11166.

Belhage B, Hansen GH, Elster L, Schousboe A (1998). Effects of gamma-aminobutyric acid (GABA) on synaptogenesis and synaptic function. Perspect Dev Neurobiol 5: 235-246.

Ben-Ari Y, Khazipov R, Leinekugel X, Caillard O, Gaiarsa JL (1997). GABAA, NMDA and AMPA receptors: a developmentally regulated 'menage a trois'. Trends Neurosci 20: 523-529. 
Benke D, Fakitsas P, Roggenmoser C, Michel C, Rudolph U, Mohler H (2004). Analysis of the presence and abundance of GABAA receptors containing two different types of alpha subunits in murine brain using point-mutated alpha subunits. J Biol Chem 279: 43654-43660.

Berger FM (1947). The mode of action of myanesin. Br J Pharmacol Chemother 2: 241-250.

Berger FM (1954). The pharmacological properties of 2-methyl-2-n-propyl-1,3-propanediol dicarbamate (miltown), a new interneuronal blocking agent. J Pharmacol Exp Ther 112: 413-423.

Berger FM (1964). Symposium on Anxiety and a Decade of Tranquilizer Therapy. The Tranquilizer Decade. J Neuropsychiatr 5: 403-410.

Berger FM, Bradley W (1946). The pharmacological properties of alpha:beta-dihydroxy-gamma(2-methylphenoxy)-propane (myanesin). Br J Pharmacol Chemother 1: 265-272.

Berger FM, Kletzkin M, Ludwig BJ, Margolin S (1960). The history, chemistry, and pharmacology of carisoprodol. Ann N Y Acad Sci 86: 90-107.

Bergmann R, Kongsbak K, Sorensen PL, Sander T, Balle T (2013). A unified model of the GABA(A) receptor comprising agonist and benzodiazepine binding sites. PLoS One 8: e52323.

Betz H, Becker CM (1988). The mammalian glycine receptor: biology and structure of a neuronal chloride channel protein. Neurochem Int 13: 137-146.

Bianchi MT, Macdonald RL (2003). Neurosteroids shift partial agonist activation of GABA(A) receptor channels from low- to high-efficacy gating patterns. J Neurosci 23: 10934-10943.

Bismuth C, Baud FJ, Galliot M, du Fretay XH, de Kerviller E (1985). [Liver metabolism of meprobamate: clinical estimation in acute intoxication]. $J$ Toxicol Clin Exp 5: 321-328.

Bonetti EP, Burkard WP, Gabl M, Hunkeler W, Lorez HP, Martin JR, et al. (1988). Ro 15-4513: partial inverse agonism at the BZR and interaction with ethanol. Pharmacol Biochem Behav 31: 733-749.

Bonin RP, Labrakakis C, Eng DG, Whissell PD, De Koninck Y, Orser BA (2011). Pharmacological enhancement of delta-subunit-containing $\mathrm{GABA}(\mathrm{A})$ receptors that generate a tonic inhibitory conductance in spinal neurons attenuates acute nociception in mice. Pain 152: 1317-1326. 
Bormann J (1988). Electrophysiology of GABAA and GABAB receptor subtypes. Trends Neurosci 11: 112-116.

Bormann J (2000). The 'ABC' of GABA receptors. Trends Pharmacol Sci 21: 16-19.

Bormann J, Feigenspan A (1995). GABAC receptors. Trends Neurosci 18: 515-519.

Boue-Grabot E, Roudbaraki M, Bascles L, Tramu G, Bloch B, Garret M (1998). Expression of GABA receptor rho subunits in rat brain. J Neurochem 70: 899-907.

Bowery N (1989). GABAB receptors and their significance in mammalian pharmacology. Trends Pharmacol Sci 10: 401-407.

Boyd L, Cammer L, Mulinos MG, Huppert VF, Hammer H (1958). Meprobamate addiction. J Am Med Assoc 168: 1839-1843.

Bradley PB, Elkes J (1957). The effects of some drugs on the electrical activity of the brain. Brain 80: 77-117.

Braestrup C, Schmiechen R, Neef G, Nielsen M, Petersen EN (1982). Interaction of convulsive ligands with benzodiazepine receptors. Science 216: 1241-1243.

Bramness JG, Skurtveit S, Morland J (2004). Impairment due to intake of carisoprodol. Drug Alcohol Depend 74: 311-318.

Bramness JG, Furu K, Skurtveit S, Engeland A (2012). Effect of the market withdrawal of carisoprodol on use of other prescribed drugs with abuse potential. Clin Pharmacol Ther 91: 438441.

Bramness JG, Morland J, Sorlid HK, Rudberg N, Jacobsen D (2005). Carisoprodol intoxications and serotonergic features. Clin Toxicol (Phila) 43: 39-45.

Brickley SG, Mody I (2012). Extrasynaptic GABA(A) receptors: their function in the CNS and implications for disease. Neuron 73: 23-34.

Brickley SG, Cull-Candy SG, Farrant M (1999). Single-channel properties of synaptic and extrasynaptic GABAA receptors suggest differential targeting of receptor subtypes. J Neurosci 19: 2960-2973. 
Brown N, Kerby J, Bonnert TP, Whiting PJ, Wafford KA (2002). Pharmacological characterization of a novel cell line expressing human alpha(4)beta(3)delta GABA(A) receptors. Br J Pharmacol 136: 965-974.

Brunig I, Scotti E, Sidler C, Fritschy JM (2002). Intact sorting, targeting, and clustering of gammaaminobutyric acid A receptor subtypes in hippocampal neurons in vitro. J Comp Neurol 443: 4355.

Chang Y, Wang R, Barot S, Weiss DS (1996). Stoichiometry of a recombinant GABAA receptor. J Neurosci 16: 5415-5424.

Charron C, Mekontso-Dessap A, Chergui K, Rabiller A, Jardin F, Vieillard-Baron A (2005). Incidence, causes and prognosis of hypotension related to meprobamate poisoning. Intensive Care Med 31: 1582-1586.

Chen $\mathrm{CH}$, Huang CC, Liao DL (2014). Association analysis of GABRB3 promoter variants with heroin dependence. PLoS One 9: e102227.

Chen JG, Sachpatzidis A, Rudnick G (1997). The third transmembrane domain of the serotonin transporter contains residues associated with substrate and cocaine binding. J Biol Chem 272: 28321-28327.

Chen ZW, Manion B, Townsend RR, Reichert DE, Covey DF, Steinbach JH, et al. (2012). Neurosteroid analog photolabeling of a site in the third transmembrane domain of the beta3 subunit of the GABA(A) receptor. Mol Pharmacol 82: 408-419.

Chiara DC, Jayakar SS, Zhou X, Zhang X, Savechenkov PY, Bruzik KS, et al. (2013). Specificity of intersubunit general anesthetic-binding sites in the transmembrane domain of the human alpha1beta3gamma2 gamma-aminobutyric acid type A (GABAA) receptor. J Biol Chem 288: 19343-19357.

Clarkson AN, Huang BS, Macisaac SE, Mody I, Carmichael ST (2010). Reducing excessive GABAmediated tonic inhibition promotes functional recovery after stroke. Nature 468: 305-309.

Cockcroft V, Ortells M, Lunt G (1995). Ligands, receptor models, and evolution. Ann N Y Acad Sci 757: 40-47.

Connolly CN, Wafford KA (2004). The Cys-loop superfamily of ligand-gated ion channels: the impact of receptor structure on function. Biochem Soc Trans 32: 529-534. 
Couve A, Moss SJ, Pangalos MN (2000). GABAB receptors: a new paradigm in G protein signaling. Mol Cell Neurosci 16: 296-312.

Crestani F, Low K, Keist R, Mandelli M, Mohler H, Rudolph U (2001). Molecular targets for the myorelaxant action of diazepam. Mol Pharmacol 59: 442-445.

Crestani F, Keist R, Fritschy JM, Benke D, Vogt K, Prut L, et al. (2002). Trace fear conditioning involves hippocampal alpha5 GABA(A) receptors. Proc Natl Acad Sci U S A 99: 8980-8985.

Cushman JD, Moore MD, Olsen RW, Fanselow MS (2014). The role of the delta GABA(A) receptor in ovarian cycle-linked changes in hippocampus-dependent learning and memory. Neurochem Res 39: 1140-1146.

Cutting GR, Lu L, O'Hara BF, Kasch LM, Montrose-Rafizadeh C, Donovan DM, et al. (1991). Cloning of the gamma-aminobutyric acid (GABA) rho 1 cDNA: a GABA receptor subunit highly expressed in the retina. Proc Natl Acad Sci U S A 88: 2673-2677.

Davies PA, Kirkness EF, Hales TG (1997). Modulation by general anaesthetics of rat GABAA receptors comprised of alpha 1 beta 3 and beta 3 subunits expressed in human embryonic kidney 293 cells. Br J Pharmacol 120: 899-909.

Delahanty RJ, Kang JQ, Brune CW, Kistner EO, Courchesne E, Cox NJ, et al. (2011). Maternal transmission of a rare GABRB3 signal peptide variant is associated with autism. Mol Psychiatry 16: 86-96.

DeLong RE, Phillis JW, Barraco RA (1985). A possible role of endogenous adenosine in the sedative action of meprobamate. Eur J Pharmacol 118: 359-362.

DeLorey TM, Handforth A, Anagnostaras SG, Homanics GE, Minassian BA, Asatourian A, et al. (1998). Mice lacking the beta3 subunit of the GABAA receptor have the epilepsy phenotype and many of the behavioral characteristics of Angelman syndrome. J Neurosci 18: 8505-8514.

Dodd JR, Christie DL (2005). Substituted cysteine accessibility of the third transmembrane domain of the creatine transporter: defining a transport pathway. J Biol Chem 280: 32649-32654.

Douglas JF, Ludwig BJ, Schlosser A (1962). The metabolic fate of carisoprodol in dog. J Pharmacol Exp Ther 138: 21-27. 
Edwards FA, Konnerth A, Sakmann B (1990). Quantal analysis of inhibitory synaptic transmission in the dentate gyrus of rat hippocampal slices: a patch-clamp study. J Physiol 430: 213-249.

Elder NC (1991). Abuse of skeletal muscle relaxants. Am Fam Physician 44: 1223-1226.

Enz R, Cutting GR (1998). Molecular composition of GABAC receptors. Vision Res 38: 1431-1441.

Enz R, Cutting GR (1999). GABAC receptor rho subunits are heterogeneously expressed in the human CNS and form homo- and heterooligomers with distinct physical properties. Eur J Neurosci 11: 41-50.

Enz R, Brandstatter JH, Hartveit E, Wassle H, Bormann J (1995). Expression of GABA receptor rho 1 and rho 2 subunits in the retina and brain of the rat. Eur J Neurosci 7: 1495-1501.

Erlander MG, Tobin AJ (1991). The structural and functional heterogeneity of glutamic acid decarboxylase: a review. Neurochem Res 16: 215-226.

Ewing JA, Fullilove RE (1957). Addiction to meprobamate. N Eng/ J Med 257: 76-77.

Fass JA (2010). Carisoprodol legal status and patterns of abuse. Ann Pharmacother 44: 1962-1967.

Fathallah N, Zamy M, Slim R, Fain O, Hmouda H, Bouraoui K, et al. (2011). Acute pancreatitis in the course of meprobamate poisoning. JOP 12: 404-406.

Feigenspan A, Bormann J (1998). GABA-gated Cl- channels in the rat retina. Prog Retin Eye Res 17: 99-126.

Feng HJ, Bianchi MT, Macdonald RL (2004). Pentobarbital differentially modulates alpha1beta3delta and alpha1beta3gamma2L GABAA receptor currents. Mol Pharmacol 66: 9881003.

Feusner J, Ritchie T, Lawford B, Young RM, Kann B, Noble EP (2001). GABA(A) receptor beta 3 subunit gene and psychiatric morbidity in a post-traumatic stress disorder population. Psychiatry Res 104: 109-117.

Friedman HT, Marmelzat WL (1956). Adverse reactions to meprobamate. J Am Med Assoc 162: 628-630. 
Fritschy JM, Mohler H (1995). GABAA-receptor heterogeneity in the adult rat brain: differential regional and cellular distribution of seven major subunits. J Comp Neurol 359: 154-194.

Fritschy JM, Johnson DK, Mohler H, Rudolph U (1998). Independent assembly and subcellular targeting of GABA(A)-receptor subtypes demonstrated in mouse hippocampal and olfactory neurons in vivo. Neurosci Lett 249: 99-102.

Gangloff H (1959). Effect of phenaglycodol and meprobamate on spontaneous brain activity, evoked EEG arousal and recruitment in the cat. J Pharmacol Exp Ther 126: 30-40.

Gilbert JD, Aylott RI, Sogtrop HH, Draffan GH (1984). The pharmacokinetics of meprobamate following its oral and rectal administration as a series of combinations with diphenhydramine, acetylsalicylic acid, codeine and pentaerythritol tetranitrate. Arzneimittelforschung 34: 13231327.

Gonzalez LA, Gatch MB, Forster MJ, Dillon GH (2009a). Abuse Potential of Soma: the GABA(A) Receptor as a Target. Mol Cell Pharmacol 1: 180-186.

Gonzalez LA, Gatch MB, Taylor CM, Bell-Horner CL, Forster MJ, Dillon GH (2009b). Carisoprodolmediated modulation of GABAA receptors: in vitro and in vivo studies. J Pharmacol Exp Ther 329: 827-837.

Greenblatt DJ, Shader RI (1971). Meprobamate: a study of irrational drug use. Am J Psychiatry 127: 1297-1303.

Greenblatt DJ, Shader RI (1974). Drug therapy. Benzodiazepines (second of two parts). N Engl J Med 291: 1239-1243.

Griebel G, Perrault G, Simiand J, Cohen C, Granger P, Depoortere H, et al. (2003). SL651498, a GABAA receptor agonist with subtype-selective efficacy, as a potential treatment for generalized anxiety disorder and muscle spasms. CNS Drug Rev 9: 3-20.

Gurley D, Amin J, Ross PC, Weiss DS, White G (1995). Point mutations in the M2 region of the alpha, beta, or gamma subunit of the GABAA channel that abolish block by picrotoxin. Receptors Channels 3: 13-20.

Hamouda AK, Stewart DS, Chiara DC, Savechenkov PY, Bruzik KS, Cohen JB (2014). Identifying barbiturate binding sites in a nicotinic acetylcholine receptor with [3H]allyl mtrifluoromethyldiazirine mephobarbital, a photoreactive barbiturate. Mol Pharmacol 85: 735-746. 
Hashimoto T, Bazmi HH, Mirnics K, Wu Q, Sampson AR, Lewis DA (2008a). Conserved regional patterns of GABA-related transcript expression in the neocortex of subjects with schizophrenia. Am J Psychiatry 165: 479-489.

Hashimoto T, Arion D, Unger T, Maldonado-Aviles JG, Morris HM, Volk DW, et al. (2008b). Alterations in GABA-related transcriptome in the dorsolateral prefrontal cortex of subjects with schizophrenia. Mol Psychiatry 13: 147-161.

Hawkinson JE, Drewe JA, Kimbrough CL, Chen JS, Hogenkamp DJ, Lan NC, et al. (1996). 3 alphaHydroxy-3 beta-trifluoromethyl-5 alpha-pregnan-20-one (Co 2-1970): a partial agonist at the neuroactive steroid site of the gamma-aminobutyric acidA receptor. Mol Pharmacol 49: 897-906.

Hendley CD, Lynes TE, Berger FM (1954). Effect of 2-methyl, 2-n-propyl-1,3-propanediol dicarbamate (Miltown) on central nervous system. Proc Soc Exp Biol Med 87: 608-610.

Hollister LE (1957). Complications from the use of tranquilizing drugs. N Eng/ J Med 257: 170-177.

Hollister LE (1983). The pre-benzodiazepine era. J Psychoactive Drugs 15: 9-13.

Hollister LE, Levy G (1964). Kinetics of Meprobamate Elimination in Humans. Chemotherapy 9: 2024.

Holoubek JE, Thomas OC, Segura J (1957). Toxic reaction to 2-methyl-2-n-propyl-1, 3, propanediol dicarbamate (miltown and equanil). Ann Intern Med 46: 1002-1004.

Hosie AM, Wilkins ME, da Silva HM, Smart TG (2006). Endogenous neurosteroids regulate GABAA receptors through two discrete transmembrane sites. Nature 444: 486-489.

Huang CC, Cheng MC, Tsai HM, Lai CH, Chen CH (2014). Genetic analysis of GABRB3 at 15q12 as a candidate gene of schizophrenia. Psychiatr Genet 24: 151-157.

Hunkeler W, Mohler H, Pieri L, Polc P, Bonetti EP, Cumin R, et al. (1981). Selective antagonists of benzodiazepines. Nature 290: 514-516.

Im WB, Pregenzer JF, Binder JA, Dillon GH, Alberts GL (1995). Chloride channel expression with the tandem construct of alpha 6-beta 2 GABAA receptor subunit requires a monomeric subunit of alpha 6 or gamma 2. J Biol Chem 270: 26063-26066. 
Inoue H, Kayano S, Aoki Y, Kure S, Yamada A, Hata A, et al. (2008). Association of the GABRB3 gene with nonsyndromic oral clefts. Cleft Palate Craniofac J 45: 261-266.

Ito T, Suzuki T, Wellman SE, Ho IK (1996). Pharmacology of barbiturate tolerance/dependence: GABAA receptors and molecular aspects. Life Sci 59: 169-195.

Jacob TC, Moss SJ, Jurd R (2008). GABA(A) receptor trafficking and its role in the dynamic modulation of neuronal inhibition. Nat Rev Neurosci 9: 331-343.

Javitch JA, Ballesteros JA, Weinstein H, Chen J (1998). A cluster of aromatic residues in the sixth membrane-spanning segment of the dopamine D2 receptor is accessible in the binding-site crevice. Biochemistry 37: 998-1006.

Johnston GA (1996). GABAc receptors: relatively simple transmitter -gated ion channels? Trends Pharmacol Sci 17: 319-323.

Kharlamov EA, Lepsveridze E, Meparishvili M, Solomonia RO, Lu B, Miller ER, et al. (2011). Alterations of $\operatorname{GABA}(\mathrm{A})$ and glutamate receptor subunits and heat shock protein in rat hippocampus following traumatic brain injury and in posttraumatic epilepsy. Epilepsy Res 95: 2034.

Kintz P, Tracqui A, Mangin P, Lugnier AA (1988). Fatal meprobamate self-poisoning. Am J Forensic Med Pathol 9: 139-140.

Kumar M, Gonzalez LA, Dillon GH (2015). Assessment of subunit-dependent direct gating and allosteric modulatory effects of carisoprodol at GABAA receptors. Neuropharmacology 97: 414425.

Lee V, Sarkar J, Maguire J (2014). Loss of Gabrd in CRH neurons blunts the corticosterone response to stress and diminishes stress-related behaviors. Psychoneuroendocrinology 41: 75-88.

Lemere F (1956). Habit-forming properties of meprobamate. AMA Arch Neurol Psychiatry 76: 205206.

Lhoste F, Lemaire F, Rapin M (1977). Treatment of hypotension in meprobamate poisoning. N Engl J Med 296: 1004.

Licata SC, Rowlett JK (2008). Abuse and dependence liability of benzodiazepine-type drugs: GABA(A) receptor modulation and beyond. Pharmacol Biochem Behav 90: 74-89. 
Licata SC, Platt DM, Cook JM, Sarma PV, Griebel G, Rowlett JK (2005). Contribution of GABAA receptor subtypes to the anxiolytic-like, motor, and discriminative stimulus effects of benzodiazepines: studies with the functionally selective ligand SL651498 [6-fluoro-9-methyl-2phenyl-4-(pyrrolidin-1-yl-carbonyl)-2,9-dihydro-1H-pyridol[3,4-b]indol-1-one]. J Pharmacol Exp Ther 313: 1118-1125.

Littrell RA, Hayes LR, Stillner V (1993). Carisoprodol (Soma): a new and cautious perspective on an old agent. South Med J 86: 753-756.

Longo VG (1956). Effects of scopolamine and atropine electroencephalographic and behavioral reactions due to hypothalamic stimulation. J Pharmacol Exp Ther 116: 198-208.

Low K, Crestani F, Keist R, Benke D, Brunig I, Benson JA, et al. (2000). Molecular and neuronal substrate for the selective attenuation of anxiety. Science 290: 131-134.

Ludwig BJ, Powell LS, Berger FM (1969). Carbamate derivatives related to meprobamate. J Med Chem 12: 462-472.

Lynch JW, Rajendra S, Barry PH, Schofield PR (1995). Mutations affecting the glycine receptor agonist transduction mechanism convert the competitive antagonist, picrotoxin, into an allosteric potentiator. J Biol Chem 270: 13799-13806.

Lynch JW, Rajendra S, Pierce KD, Handford CA, Barry PH, Schofield PR (1997). Identification of intracellular and extracellular domains mediating signal transduction in the inhibitory glycine receptor chloride channel. EMBO J 16: 110-120.

Macdonald RL, Kang JQ, Gallagher MJ (2010). Mutations in GABAA receptor subunits associated with genetic epilepsies. J Physiol 588: 1861-1869.

Maddock RK, Jr., Bloomer HA (1967). Meprobamate overdosage. Evaluation of its severity and methods of treatment. JAMA 201: 999-1003.

Maguire J, Mody I (2008). GABA(A)R plasticity during pregnancy: relevance to postpartum depression. Neuron 59: 207-213.

Maguire J, Ferando I, Simonsen C, Mody I (2009). Excitability changes related to GABAA receptor plasticity during pregnancy. J Neurosci 29: 9592-9601. 
Maguire JL, Stell BM, Rafizadeh M, Mody I (2005). Ovarian cycle-linked changes in GABA(A) receptors mediating tonic inhibition alter seizure susceptibility and anxiety. Nat Neurosci 8: 797804.

Maldonado-Aviles JG, Curley AA, Hashimoto T, Morrow AL, Ramsey AJ, O'Donnell P, et al. (2009). Altered markers of tonic inhibition in the dorsolateral prefrontal cortex of subjects with schizophrenia. Am J Psychiatry 166: 450-459.

Marshall FH, Jones KA, Kaupmann K, Bettler B (1999). GABAB receptors - the first 7TM heterodimers. Trends Pharmacol Sci 20: 396-399.

McKernan RM, Rosahl TW, Reynolds DS, Sur C, Wafford KA, Atack JR, et al. (2000). Sedative but not anxiolytic properties of benzodiazepines are mediated by the GABA(A) receptor alpha1 subtype. Nat Neurosci 3: 587-592.

McKinley DD, Lennon DJ, Carter DB (1995). Cloning, sequence analysis and expression of two forms of mRNA coding for the human beta 2 subunit of the GABAA receptor. Brain Res Mol Brain Res 28: 175-179.

Meldrum BS (2000). Glutamate as a neurotransmitter in the brain: review of physiology and pathology. J Nutr 130: 1007S-1015S.

Merali Z, Du L, Hrdina P, Palkovits M, Faludi G, Poulter MO, et al. (2004). Dysregulation in the suicide brain: mRNA expression of corticotropin-releasing hormone receptors and GABA(A) receptor subunits in frontal cortical brain region. J Neurosci 24: 1478-1485.

Meyer LM, Heeve WL, Bertscher RW (1957). Aplastic anemia after meprobamate (2-methyl-2-Npropyl-1,3-propanediol dicarbamate) therapy. N Engl J Med 256: 1232-1233.

Miller PS, Aricescu AR (2014). Crystal structure of a human GABAA receptor. Nature 512: 270-275.

Mistry DK, Cottrell GA (1990). Actions of steroids and bemegride on the GABAA receptor of mouse spinal neurones in culture. Exp Physiol 75: 199-209.

Miyazawa A, Fujiyoshi Y, Unwin N (2003). Structure and gating mechanism of the acetylcholine receptor pore. Nature 423: 949-955.

Mody I, De Koninck Y, Otis TS, Soltesz I (1994). Bridging the cleft at GABA synapses in the brain. Trends Neurosci 17: 517-525. 
Mohler H, Battersby MK, Richards JG (1980). Benzodiazepine receptor protein identified and visualized in brain tissue by a photoaffinity label. Proc Natl Acad Sci U S A 77: 1666-1670.

Mohr RC, Mead BT (1958). Meprobamate addiction. N Engl J Med 259: 865-868.

Moss SJ, Smart TG (2001). Constructing inhibitory synapses. Nat Rev Neurosci 2: 240-250.

Mtchedlishvili Z, Lepsveridze E, Xu H, Kharlamov EA, Lu B, Kelly KM (2010). Increase of GABAA receptor-mediated tonic inhibition in dentate granule cells after traumatic brain injury. Neurobiol Dis 38: 464-475.

Nayeem N, Green TP, Martin IL, Barnard EA (1994). Quaternary structure of the native GABAA receptor determined by electron microscopic image analysis. J Neurochem 62: 815-818.

Nusser Z, Cull-Candy S, Farrant M (1997). Differences in synaptic GABA(A) receptor number underlie variation in GABA mini amplitude. Neuron 19: 697-709.

O'Toole KK, Jenkins A (2012). The apparent voltage dependence of GABAA receptor activation and modulation is inversely related to channel open probability. Mol Pharmacol 81: 189-197.

Olsen H, Koppang E, Alvan G, Morland J (1994). Carisoprodol elimination in humans. Ther Drug Monit 16: 337-340.

Olsen RW, Sieghart W (2008). International Union of Pharmacology. LXX. Subtypes of gammaaminobutyric acid $(A)$ receptors: classification on the basis of subunit composition, pharmacology, and function. Update. Pharmacol Rev 60: 243-260.

Orser BA, Wang LY, Pennefather PS, MacDonald JF (1994). Propofol modulates activation and desensitization of GABAA receptors in cultured murine hippocampal neurons. J Neurosci 14: 77477760.

Paydar A, Lee B, Gangadharan G, Lee S, Hwang EM, Shin HS (2014). Extrasynaptic GABAA receptors in mediodorsal thalamic nucleus modulate fear extinction learning. Mol Brain 7: 39.

Pennington VM (1957). Use of Miltown (meprobamate) with psychotic patients. Am J Psychiatry 114: 257-260. 
Pribilla I, Takagi T, Langosch D, Bormann J, Betz H (1992). The atypical M2 segment of the beta subunit confers picrotoxinin resistance to inhibitory glycine receptor channels. EMBO J 11: 43054311.

Pritchett DB, Sontheimer H, Shivers BD, Ymer S, Kettenmann H, Schofield PR, et al. (1989). Importance of a novel GABAA receptor subunit for benzodiazepine pharmacology. Nature 338: 582-585.

Reeves RR, Parker JD (2003). Somatic dysfunction during carisoprodol cessation: evidence for a carisoprodol withdrawal syndrome. J Am Osteopath Assoc 103: 75-80.

Rho JM, Donevan SD, Rogawski MA (1994). Mechanism of action of the anticonvulsant felbamate: opposing effects on $\mathrm{N}$-methyl-D-aspartate and gamma-aminobutyric acidA receptors. Ann Neurol 35: 229-234.

Rho JM, Donevan SD, Rogawski MA (1997). Barbiturate-like actions of the propanediol dicarbamates felbamate and meprobamate. J Pharmacol Exp Ther 280: 1383-1391.

Rivera C, Voipio J, Payne JA, Ruusuvuori E, Lahtinen H, Lamsa K, et al. (1999). The $\mathrm{K}+/ \mathrm{Cl}$ - cotransporter KCC2 renders GABA hyperpolarizing during neuronal maturation. Nature 397: 251255.

Rudolph U, Mohler H (2004). Analysis of GABAA receptor function and dissection of the pharmacology of benzodiazepines and general anesthetics through mouse genetics. Annu Rev Pharmacol Toxicol 44: 475-498.

Rudolph U, Knoflach F (2011). Beyond classical benzodiazepines: novel therapeutic potential of GABAA receptor subtypes. Nat Rev Drug Discov 10: 685-697.

Rudolph U, Mohler H (2014). GABAA receptor subtypes: Therapeutic potential in Down syndrome, affective disorders, schizophrenia, and autism. Annu Rev Pharmacol Toxicol 54: 483-507.

Rudolph U, Crestani F, Benke D, Brunig I, Benson JA, Fritschy JM, et al. (1999). Benzodiazepine actions mediated by specific gamma-aminobutyric acid(A) receptor subtypes. Nature 401: 796800.

Rust GS, Hatch R, Gums JG (1993). Carisoprodol as a drug of abuse. Arch Fam Med 2: 429-432. 
Sarkar J, Wakefield S, Mackenzie G, Moss SJ, Maguire J (2011). Neurosteroidogenesis is required for the physiological response to stress: role of neurosteroid-sensitive GABAA receptors. J Neurosci 31: 18198-18210.

Schechter MD (1984). Specific antagonism of the behavioral effects of chlordiazepoxide and pentobarbital in the rat. Prog Neuropsychopharmacol Biol Psychiatry 8: 359-364.

Schoch P, Richards JG, Haring P, Takacs B, Stahli C, Staehelin T, et al. (1985). Co-localization of GABA receptors and benzodiazepine receptors in the brain shown by monoclonal antibodies. Nature 314: 168-171.

Schofield PR, Darlison MG, Fujita N, Burt DR, Stephenson FA, Rodriguez H, et al. (1987). Sequence and functional expression of the GABA A receptor shows a ligand-gated receptor super-family. Nature 328: 221-227.

Sedelnikova A, Erkkila BE, Harris H, Zakharkin SO, Weiss DS (2006). Stoichiometry of a pore mutation that abolishes picrotoxin-mediated antagonism of the GABAA receptor. J Physiol 577: 569-577.

Shah YD, Singh K, Friedman D, Devinsky O, Kothare SV (2016). Evaluating the safety and efficacy of felbamate in the context of a black box warning: A single center experience. Epilepsy Behav 56: 50-53.

Shan Q, Haddrill JL, Lynch JW (2001). Ivermectin, an unconventional agonist of the glycine receptor chloride channel. J Biol Chem 276: 12556-12564.

Shen H, Gong QH, Yuan M, Smith SS (2005). Short-term steroid treatment increases delta GABAA receptor subunit expression in rat CA1 hippocampus: pharmacological and behavioral effects. Neuropharmacology 49: 573-586.

Shimada S, Cutting G, Uhl GR (1992). gamma-Aminobutyric acid A or C receptor? gammaAminobutyric acid rho 1 receptor RNA induces bicuculline-, barbiturate-, and benzodiazepineinsensitive gamma-aminobutyric acid responses in Xenopus oocytes. Mol Pharmacol 41: 683-687.

Sieghart W (1995). Structure and pharmacology of gamma-aminobutyric acidA receptor subtypes. Pharmacol Rev 47: 181-234.

Siegwart R, Jurd R, Rudolph U (2002). Molecular determinants for the action of general anesthetics at recombinant alpha(2)beta(3)gamma(2)gamma-aminobutyric acid(A) receptors. $J$ Neurochem 80: 140-148. 
Sigel E, Buhr A (1997). The benzodiazepine binding site of GABAA receptors. Trends Pharmacol Sci 18: 425-429.

Sine SM, Engel AG (2006). Recent advances in Cys-loop receptor structure and function. Nature 440: 448-455.

Smith SS, Ruderman Y, Frye C, Homanics G, Yuan M (2006). Steroid withdrawal in the mouse results in anxiogenic effects of 3alpha,5beta-THP: a possible model of premenstrual dysphoric disorder. Psychopharmacology (Berl) 186: 323-333.

Stroud GM (1957). Drug eruptions due to meprobamate. N Engl J Med 256: 354-355.

Sullivan MD (2015). What are we treating with opioid and sedative-hypnotic combination therapy? Pharmacoepidemiol Drug Saf 24: 893-895.

Taboulet P, Bismuth C (1994). [Shock caused by poisoning. Use of cardiotropic agents]. Presse Med 23: 1263-1268.

Tan KR, Brown M, Labouebe G, Yvon C, Creton C, Fritschy JM, et al. (2010). Neural bases for addictive properties of benzodiazepines. Nature 463: 769-774.

Tang X, Hernandez CC, Macdonald RL (2010). Modulation of spontaneous and GABA-evoked tonic alpha4beta3delta and alpha4beta3gamma2L GABAA receptor currents by protein kinase A. J Neurophysiol 103: 1007-1019.

Thompson AJ, Lester HA, Lummis SC (2010). The structural basis of function in Cys-loop receptors. Q Rev Biophys 43: 449-499.

Toth PP, Urtis J (2004). Commonly used muscle relaxant therapies for acute low back pain: a review of carisoprodol, cyclobenzaprine hydrochloride, and metaxalone. Clin Ther 26: 1355-1367.

Toyoshima C, Unwin N (1990). Three-dimensional structure of the acetylcholine receptor by cryoelectron microscopy and helical image reconstruction. J Cell Biol 111: 2623-2635.

Tretter V, Ehya N, Fuchs K, Sieghart W (1997). Stoichiometry and assembly of a recombinant GABAA receptor subtype. J Neurosci 17: 2728-2737.

Underwood TW, Frye CB (1993). Drug-induced pancreatitis. Clin Pharm 12: 440-448. 
Unwin N (1993). Neurotransmitter action: opening of ligand-gated ion channels. Cell 72 Suppl: 3141.

van Rijnsoever C, Tauber M, Choulli MK, Keist R, Rudolph U, Mohler H, et al. (2004). Requirement of alpha5-GABAA receptors for the development of tolerance to the sedative action of diazepam in mice. J Neurosci 24: 6785-6790.

Verpooten GA, De Broe ME (1982). Prediction of the efficacy of hemoperfusion and hemodialysis in severe poisoning. Arch Toxicol Supp/ 5: 304-306.

Wafford KA (2005). GABAA receptor subtypes: any clues to the mechanism of benzodiazepine dependence? Curr Opin Pharmacol 5: 47-52.

Wagoner KR, Czajkowski C (2010). Stoichiometry of expressed alpha(4)beta(2)delta gammaaminobutyric acid type A receptors depends on the ratio of subunit CDNA transfected. $J$ Biol Chem 285: 14187-14194.

Wallis RA, Panizzon KL, Fairchild MD, Wasterlain CG (1992). Protective effects of felbamate against hypoxia in the rat hippocampal slice. Stroke 23: 547-551.

Whissell PD, Lecker I, Wang DS, Yu J, Orser BA (2015). Altered expression of deltaGABAA receptors in health and disease. Neuropharmacology 88: 24-35.

Whissell PD, Eng D, Lecker I, Martin LJ, Wang DS, Orser BA (2013). Acutely increasing deltaGABA(A) receptor activity impairs memory and inhibits synaptic plasticity in the hippocampus. Front Neural Circuits 7: 146.

Whiting P, McKernan RM, Iversen LL (1990). Another mechanism for creating diversity in gammaaminobutyrate type A receptors: RNA splicing directs expression of two forms of gamma 2 phosphorylation site. Proc Natl Acad Sci U S A 87: 9966-9970.

Williams CA, Angelman H, Clayton-Smith J, Driscoll DJ, Hendrickson JE, Knoll JH, et al. (1995). Angelman syndrome: consensus for diagnostic criteria. Angelman Syndrome Foundation. Am J Med Genet 56: 237-238.

Witenko C, Moorman-Li R, Motycka C, Duane K, Hincapie-Castillo J, Leonard P, et al. (2014). Considerations for the appropriate use of skeletal muscle relaxants for the management of acute low back pain. P T 39: 427-435. 
Wlodarczyk Al, Sylantyev S, Herd MB, Kersante F, Lambert JJ, Rusakov DA, et al. (2013). GABAindependent GABAA receptor openings maintain tonic currents. J Neurosci 33: 3905-3914.

Wohlfarth KM, Bianchi MT, Macdonald RL (2002). Enhanced neurosteroid potentiation of ternary GABA(A) receptors containing the delta subunit. J Neurosci 22: 1541-1549.

Xu M, Akabas MH (1996). Identification of channel-lining residues in the M2 membrane-spanning segment of the GABA(A) receptor alpha1 subunit. J Gen Physiol 107: 195-205.

Zacny JP, Paice JA, Coalson DW (2011). Characterizing the subjective and psychomotor effects of carisoprodol in healthy volunteers. Pharmacol Biochem Behav 100: 138-143.

Zacny JP, Paice JA, Coalson DW (2012). Subjective and psychomotor effects of carisoprodol in combination with oxycodone in healthy volunteers. Drug Alcohol Depend 120: 229-232.

Zhang D, Pan ZH, Zhang X, Brideau AD, Lipton SA (1995). Cloning of a gamma-aminobutyric acid type $C$ receptor subunit in rat retina with a methionine residue critical for picrotoxinin channel block. Proc Natl Acad Sci U S A 92: 11756-11760. 